$\infty$

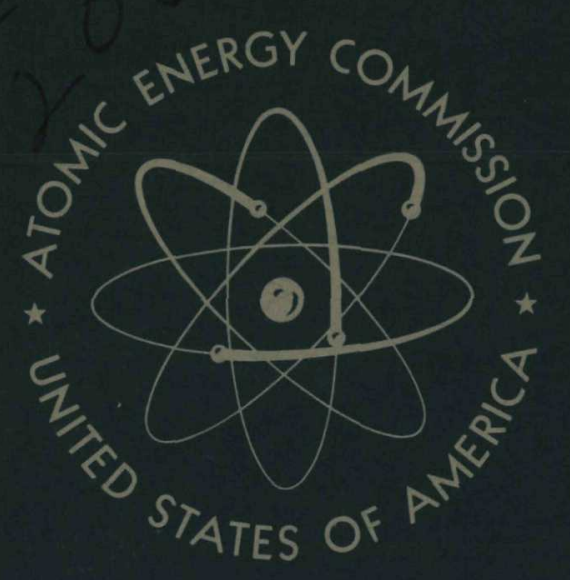

\title{
CIVIIUAN PQDWVIR
}

\section{IBDACTAIR PIBDGRAM}

\section{PART III}

\section{Status Report \\ on Fast Reactors \\ as of 1959}

UNITED STATIS ATOMIC ENGBGY CDMMISSIDN 


\section{DISCLAIMER}

This report was prepared as an account of work sponsored by an agency of the United States Government. Neither the United States Government nor any agency Thereof, nor any of their employees, makes any warranty, express or implied, or assumes any legal liability or responsibility for the accuracy, completeness, or usefulness of any information, apparatus, product, or process disclosed, or represents that its use would not infringe privately owned rights. Reference herein to any specific commercial product, process, or service by trade name, trademark, manufacturer, or otherwise does not necessarily constitute or imply its endorsement, recommendation, or favoring by the United States Government or any agency thereof. The views and opinions of authors expressed herein do not necessarily state or reflect those of the United States Government or any agency thereof. 


\section{DISCLAIMER}

Portions of this document may be illegible in electronic image products. Images are produced from the best available original document. 


\section{LEGAL NOTICE}

This report was prepared as an account of Government sponsored work. Neither the United States, nor the Commission, nor any person acting on behalf of the Commission:

A. Makes any warranty or representation, expressioned or implied, with respect to the accuracy, completeness, or usefulness of the information contained in this report, or that the use of any information, apparatus, method, or process disclosed in this report may not infringe privately owned rights; or

B. Assumes any liabilities with respect to the use of, or for damages resulting from the use of any information, apparatus, method, or process disclosed in this report.

As used in the above, "person acting on behalf of the Commission" includes any employee or contractor of the Commission, or employee of such contractor, to the extent that such employee or contractor of the Commission, or employee of such contractor prepares, disseminates, or provides access to, any information pursuant to his employment or contract with the Commission, or his employment with such contractor. 


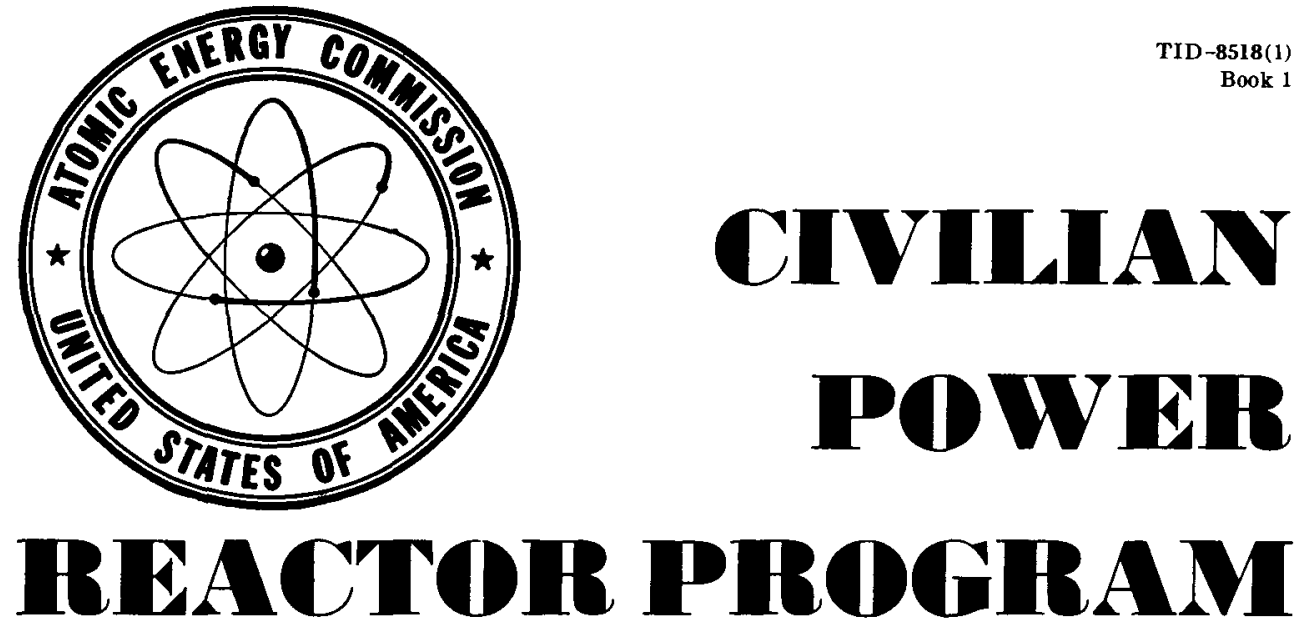

\section{PART III}

Status Report on Fast Reactors

as of 1959

Published : 1960

UNITED STATES ATOMIC ENERGY COMMISSION For ale by the Superintendent of Documents, U.S. Government Printing Office, Washington 25, D.C. - Price \$1 



\section{TABLE OF CONTENTS}

List OF ILLUSTRations.

SUMMARY _. _.

Description OF Fast Reactor TYPE.

OBJECTIVES

General Research and Development Completed and Underway $\ldots \ldots \ldots \ldots$

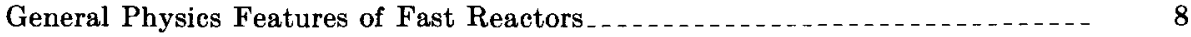

Physics Experiments and Calculations_._. 8

Cross-Section Data._. 8

Critical Experiments

Calculations

Fuel and Materials Properties

ANL Fuel . . . . . .

APDA-Sponsored Fuel

Fast Oxide Brceder Program.

Other Materials

Heat Transfer.

ANL_

Enrico Fermi Plant.

Fluid Flow Experiments $\ldots \ldots$

ANI

Enrico Fermi Plant.

Coolant Chemistry

ANL $\ldots \ldots \ldots$

Enrico Fermi Plant

Reactor Safety

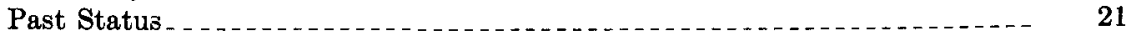

Present Status.......... 22

EBR-I Kinetic Studies.

TREAT

Containment.

Components and Systems

ANL_

KAPL S1G and S2G

EFAPP

Fuel and Materials Properties

$\mathrm{UO}_{2}$ Stainless Steel Dispersion Fuel Elements

Reactors Completed or UNDERWAY

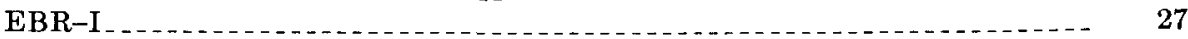

Clementine

EBR-II

Enrico Fermi Plant

British Fast Reactor Effort

Russian Fast Reactor Effort

Other Fast Reactor Effort $\ldots \ldots \ldots$

Reactors Under STUdY

Plutonium-Fueled Fast Breeder Reactor

Construction and Operating Schedules. 39

Inherent Problems and Limitations.

Appendix A-Data on Reactors Underway

Appendix B-PFFBR Design Parameters

Appendix C-Schedules

Appendix D-Drawings.

Appendix E-BIBLIOGRAPHY 83 


\section{LIST OF ILLUSTRATIONS}

\begin{tabular}{|c|c|c|}
\hline gure No. & & Page \\
\hline 1 & EBR-II Construction and Operation Schedule... & 51 \\
\hline 2 & $\begin{array}{l}\text { Summary Construction Schedule and Progress Chart for Enrico Fermi } \\
\text { Atomic Power Plant (EFAPP) }\end{array}$ & \\
\hline 3 & $\begin{array}{l}\text { Engineering Design, Procurement and Construction Schedule for the } \\
\text { Plutonium-fueled Fast Breeder Reactor (PFFBR) }\end{array}$ & 52 \\
\hline 4 & Horizontal Cross Section at Midplane of Mark II Core for EBR-I & 55 \\
\hline 5 & EBR-I Heat Flow Diagram & 56 \\
\hline 6 & EBR-I Mark III Fuel Rod & 57 \\
\hline 7 & EBR-I Mark III Reactor Cross Section & 58 \\
\hline 8 & EBR-I Mark III Inner Tank Assembly & 59 \\
\hline 9 & Cutaway Drawing of EBR-II Plant & 60 \\
\hline 10 & Vertical Section of EBR-II Plant. & 61 \\
\hline 11 & Horizontal Sections of EBR-II Plant & 62 \\
\hline 12 & EBR-II Fuel Handling System....... & 63 \\
\hline 13 & EBR-II Reactor Elevation & 64 \\
\hline 14 & Plan View of the EBR-II Reactor Arrangement & 65 \\
\hline 15 & EBR-II Flow Diagram & 66 \\
\hline 16 & Perspective View of the EFAPP Reactor & 67 \\
\hline 17 & EFAPP Reactor Arrangement & 68 \\
\hline 18 & EFAPP Plant Arrangement & 69 \\
\hline 19 & Location of Equipment in the EFAPP & 70 \\
\hline 20 & Elevation of Reactor Plant (EFAPP) & 71 \\
\hline 21 & Plan View of Reactor Plant Below Operating Floor (EFAPP) & 72 \\
\hline 22 & EFAPP Reactor Vessel (Elevation) _ & 73 \\
\hline 23 & EFAPP Reactor Vessel (Dimensional) & 74 \\
\hline 24 & EFAPP Reactor Cross Section & 75 \\
\hline 25 & $\begin{array}{l}\text { Cross Section of Steam Generator Building, Auxiliary Bay, and Turbine } \\
\text { House (EFAPP) }\end{array}$ & 76 \\
\hline 26 & Flow Diagram of the Nuclear Power Plant (EFAPP) & 77 \\
\hline 27 & PFFBR Plant Layout & 78 \\
\hline 28 & PFFBR Plan View of Primary and Secondary Systems & 79 \\
\hline 29 & PFFBR Reactor Vessel & 80 \\
\hline 30 & PFFBR Reactor Cross Section $\ldots \ldots$ & 81 \\
\hline 31 & PFFBR Flow Diagram for Primary and Secondary Sodium Systems...-- & 82 \\
\hline
\end{tabular}




\section{SUMMARY}

\section{Description and Advantages of Fast Reactors}

In the fast reactor, no attempt is made to slow down the neutrons. The neutrons are only slowed down by inelastic collision with structural and fissile materials to about 0.1 to 0.2 Mev. The characteristics obtained by operation at high neutron energy are (1) a small core with high power density, (2) a high breeding ratio, (3) low parasitic absorption of neutrons by structural materials and fission products, (4) freedom from large hot spot effects existent in some thermal reactors, (5) small reactivity requirements for control, and (6) a fuel element lifetime limited only by irradiation damage considerations. Because sodium is used as the coolant, a high thermal efficiency is attainable with low operating pressure for the primary system.

\section{Objectives}

Simply stated, the objective of the fast reactor program is to achieve economic power while burning a large fraction of the source uranium.

The reactor would operate on a closed fuel cycle to assure high utilization of uranium. Because $\mathrm{Pu}^{240}$ and $\mathrm{Pu}^{241}$ will build up in this operation, the fuel material to be handled will be radioactive with $a, \beta$, and neutron particles.

A major goal is the development of a lowcost fuel cycle. Because the raw material costs for the fuel cycle are small, the basic operations required to fabricate and reprocess the fuel elements need not be complicated, and the volume of material to be handled is small, low fuel cycle cost should be achievable. The following fuel cycle cost targets are set: (1) 2 mills/ $/ \mathrm{kw}$ hr by 1968, and (2) less than $1 \mathrm{mill} / \mathrm{kw}$ hr by 1975. To achieve these objectives fuel elements capable of attaining high burnup and also possibly with low fabrication cost should be developed. In order to achieve a high utilization of uranium, the plutonium buildup to cycle loss ratio in the blanket should be above about 4:1. To accomplish this it appears that blanket elements capable of 4 percent Pu buildup per cycle should be developed.

Another major goal is the achievement of a low capital cost for the plant. For the 1968 plant, the following targets are set: (1) Produce steam at conditions achievable in a conventional plant, (2) more fully utilize cheap, high strength materials of construction in the plant, (3) cheapen the heat transport equipment by utilizing the higher rise and greater temperature differences which can be used with sodium, (4) simplify the plant by taking advantage of better design understanding, and (5) improve mechanism by developing better design data and by simplifying designs.

For 1975 plants, develop new reactor concepts such as paste fueled and binary fluid direct cycle plants; investigate major developments for components, such as use of liquid lithium-6 for control; and simplify blanket design.

\section{General Research and Development}

Sufficient work has been done to confirm the characteristics of the fast reactor.

Physiss.-Critical experiments have been run for moderate size $\mathrm{U}^{235}$ fuel reactors, and calculated critical masses have been checked within a few percent. Important reactivity coefficients have been checked by differential experiments. Worth of the control materials for the Experimental Breeder Reactor No. 2 EBR-II and the Enrico Fermi Atomic Power Plant reactors have been checked. These data are sufficient for reactors being constructed. However, much information is re- 
quired for future fast reactors. Primarily, these reactors will be plutonium fueled and will be larger. Probably the blanket arrangement and possibly its neutron energy will be different than the present reactors. The following important types of deficiencies exist in the physies area :

(1) Alpha for plutonium in the $0.1 \mathrm{Mev}$ range is not known within a factor of two. This is important to both breeding ratio and control.

(2) Delayed neutron fractions for plutonium-fueled reactors are not well established.

(3) The reactivity coefficients for large $\mathrm{Pu}$ fast reactors will not be well known until certain special critical experiments are run. Additional codes may be necessary to achieve satisfactory methods of calculating these coefficients.

Fuels and materials.-The fast reactor is capable of operating at high temperature and to high burnup. It therefore has an excellent economic potential. Little has been done to fully exploit this potential. Data are available on the irradiation stability of alloy systems of the $10 \mathrm{w} / \mathrm{o}$ molybdenum class. Perhaps $\$ 20$ million has been spent developing this class of materials for uranium fuels. The data indicate a moderate degree of success at 2 percent burnup and a temperature up to $1,100^{\circ} \mathrm{F}$. The objective is about 5 percent burnup and $1,400^{\circ}$ F. for this system. Further work should be concentrated on plutonium alloys, methods of accommodating growth, and on cladding materials capable of high temperature operations.

The AEC has carried out extensive work on cermet fuel elements, but with inert matrix material; 25 percent burnup of the uranium in the dispersed phase has been successfully achieved. This type of fuel element can be adopted to give an economic fuel cycle for the fast reactor, but its breeding ratio will be only about 1.0. Therefore, fuel elements with fertile matrix material, which are capable of breeding ratios above 1.4 , must be developed for a fuel temperature of $1,400^{\circ} \mathrm{F}$.
The AEC has done extensive work on ceramic fuel systems, particularly the oxide systems. The results are encouraging but do not correspond to the conditions in a fast reactor. For this type of fuel it is desirable to achieve 25 percent burnup of the uranium and plutonium atoms present. The fuel elements should be easy to fabricate and should be high power density elements. Most present programs do not appear to be directed toward these objectives.

Heat transfer experiments.-The basic heat transfer characteristics of liquid metal coolants, particularly sodium, are very good. Because the heat transfer film coefficients are so good, they are not controlling and present heat transfer correlations are adequate. More data are needed in some specific areas such as the effect of thermal shock on fatigue strength of materials and the effect of oxide and other films on the behavior of some fuel elements. The performance of the steam generator is discussed in the section Components and Systems.

Fluid flow.-Because the fluid flow behavior can be correlated with that for other fluids, such as water, the general information available is adequate. Special problems need further investigation. Some of them are: (1) The nature of fog formation in the inert cover gas, (2) removal of vapor in vapor traps to prevent plugging of gas lines, and (3) flow distribution for unique geometries.

Coolant chemistry.-As a result of the operation of large system performances, the general behavior of sodium coolant systems has been determined and is considered to be excellent. This plant operated with no sign of sodium corrosion or mass transport in the sodium system, and it is felt that operation below $1,000^{\circ} \mathrm{F}$. has been satisfactorily demonstrated. Further information is desired on some special materials and on operation with a cover gas such as nitrogen. Extensive operation at temperatures of $1,200^{\circ} \mathrm{F}$. to $1,300^{\circ} \mathrm{F}$. is desired.

Mass transport of carbon is of concern if certain materials like $21 / 2$ percent $\mathrm{Cr}, 11 / 4$ percent Mo steel is used. This is not a problem asso- 
ciated with the coolant but with diffusion of carbon out of the chrome-Mo steel and absorption by stainless steel.

More refined methods of purifying sodium, particularly of oxygen, are required. Improved purity inspection is required. An AEC program is under way for oxygen removal. The problem of detecting ruptured fuel elements has not been solved and requires attention.

In general, the basic behavior of sodium has been excellent. It is a rather new coolant; therefore, the broad chemical analyses which have been developed for water have not yet been developed for sodium. Although excellent work has been done on $\mathrm{Na}-\mathrm{H}_{2} \mathrm{O}$ and $\mathrm{Na}$-Air reactions, further tests should be carried to a more quantitative conclusion.

Reactor safety.-Questions have been raised concerning the inherent safety characteristics of the fast reactor because of the behavior and meltdown of the Experimental Breeder Reactor No. 1 (EBR-I) during special reactor physics tests. For this reason, the many features of fast power reactors related to safety and control have been extensively studied both in the United States and in England. In the United States the bulk of this work has been done by Argonne National Laboratory, Los Alamos Scientific Laboratory, and by Atomic Power Development Associates, Inc. (APDA) and its contractors. The positive temperature coefficient once connected with the EBR-I has been eliminated, and it has thus been established that there are no inherent nuclear characteristics in fast reactors which make them less safe than other types. Consequently, no special or extra costs are involved in providing for the fast reactor the safety features required to contain or otherwise control the hazards of radiation.

Extensive work is being carried out on reactor safety associated with characteristics attributed to fast reactors. The problem receiving most attention is supercriticality and consequent energy release associated with nonmoderated systems with high concentration of fissionable material. The results to date have been encouraging, but analyses have not been extended to plu- tonium systems nor to the larger reactors of the 10-year program. Safety programs should be reviewed after reference reactor systems are established. In the meantime, generalized studies should be carried out. In addition to the studies on cross sections, alpha, beta, and temperature coefficients of reactivity, further work should be done on bowing of fuel subassemblies and on the nature of plutonium system meltdowns.

Component and auxiliary systems.-Operation of EBR-I, the one-tenth-scale model of EBR-II, and individual component tests have demonstrated that high temperature, compact reactors cooled with a coolant which reacts with air can be successfully operated. The remarkable situation is that the sodium-cooled reactors designed to date have been designed on the basis of "make it work" rather than for economy. In spite of this, sodium-cooled reactors are comparable in first cost with other reactor types. What has been demonstrated is that reactor mechanisms can be operated in sodium and sodium vapor and that heat exchangers can be designed for radioactive sodium service. Preliminary studies have been made which show that substantial improvements can be made in fuel handling equipment and other mechanisms if a better understanding of the performance of these mechanisms in high-temperature sodium can be obtained. One example will illustrate the point. Because of early experiments, it was considered that bearings operated in sodium should be loaded to only one one-hundredth the load for a bearing operated in oil. The British found they had to operate at 10 times this load; and their experiments showed that as long as sodium oxide (particles) was kept out of the bearing, the bearing worked fine at the higher load. The way to keep the sodium oxide out of the bearing was to examine it infrequently, thereby minimizing exposing the sodium to air.

An illustration of the improvement that can be made in the intermediate heat exchangers is the comparison of the heat exchanger design used for the Enrico Fermi plant with the type which resulted from the $\mathrm{AEC}$ high-temperature 
components study. The price can be cut almost in half, and a savings of over $\$ 1$ million can be effected in a 300-Mwe plant. Two things were done: A better tube header arrangement was designed and the shielding was located so as to simplify the heat exchanger.

This type of improvement is possible in other areas. Design data on methods of removing heat from fuel elements can greatly simplify the fuel handling and decay system.

For the Enrico Fermi plant, APDA developed a single-walled, once-through-type steam generator. Although close to $\$ 1$ million was spent on this development, more than this amount was saved by its use in the Enrico Fermi plant. Long-term performance tests are desired on any steam generator used. Water side corrosion information is particularly desired.

The maximum operating temperature to which sodium can be successfully handled without corrosion in standard materials of construction has not been established: it is believed to be about $1,200^{\circ}-1,300^{\circ}$ F. Reactor systems which have been operated or which are under construction have been limited to $900^{\circ} \mathrm{F}$., except for the short-time Sodium Reactor Experiment (SRE) demonstration at $1,000^{\circ} \mathrm{F}$. The potential of sodium systems is, therefore, not being fully utilized at this time.

\section{Reactors}

$E B R-I$-Operation of this reactor, which was the first reactor to produce power, began in December 1951. As a result of its operation, the principles of operation of a fast reactor cooled with NaK were successfully demonstrated. It fully achieved its objective. Considerable effort was expended to obtain refined physics information for which it was not designed; however, it essentially has been done. Plans are now under way to load the reactor with plutonium.
$E B R-I I$.-This reactor is a $60-\mathrm{Mwt}, 20-\mathrm{Mwe}$ fast reactor with an integrated pyrometallurgical processing plant. It is now being constructed at the National Reactor Testing Station (NRTS) and is expected to go critical in December 1960. The design and construction is progressing satisfactorily, and no unforeseen problems exist. The fuel elements are onesixth-m.-diameter fissium alloy which is sodium-bonded to stainless steel tubes. Control is by fuel movement. The major components and the fuel elements have been proved by separate tests. This plant will be operated on a recycle basis and ultimately with plutonium fuel.

Enrico Fermi reactor.-This developmental reactor is designed for initial operation at 300 Mwt and 100 Mwe. The sodium temperatures are $550^{\circ}-800^{\circ} \mathrm{F}$. for initial operation and $600^{\circ}-$ $900^{\circ} \mathbf{F}$. for final operation at high power outputs. The fuel elements are one-sixth-inchdiameter $10 \mathrm{w} / \mathrm{o}$ Mo-U alloy which is metallurgically clad to zirconium. Offsite aqueous reprocessing will be used. The primary system of the plant is essentially complete, the preliminary operation of mechanisms has begun. The erection and preliminary operation has proven to be satisfactory. The primary system will be operated with dummy fuel elements as a nonnuclear test facility for 1 year with sodium at plant temperatures. This test is expected to confirm mechanical and hydraulic operation of the primary system and to demonstrate its integrity. The plant is expected to go critical in the fall of 1960 . The operation of this plant and the EBR-II plant should demonstrate the feasibility and practicality of these plants operating on $\mathbf{U}^{235}$.

Other reactors.-The British are constructing a reactor of the same size as EBR-II. It attained criticality in November 1959. The Russians are operating one $5-\mathrm{Mw}$ reactor for fuel development and have started the design of a larger reactor. 


\section{DESCRIPTION OF FAST REACTOR TYPE}

In the fast reactor, no attempt is made to slow down the neutrons. The neutrons are only slowed down by inelastic collision with structural and fissile materials to about 0.1 to 0.2 Mev. The advantages of operation at higher energy are the small neutron absorption of structural material and fission products, the large number of neutrons produced per absorption in fuel, and the high fast fission effect. These result in the ability to attain breeding ratios of the order of 1.2 in $U^{235}$ fueled reactors, 1.4 in plutonium fueled reactors, and about 1.3 in $\mathrm{U}^{233}$ fueled reactors. The small cross sections of structural materials make it possible to choose materials independent of their cross sections; therefore, stainless steel and molybdenum are used without restriction. The small cross section of fission products and the modest reactivity coefficients make possible the operation of a fact reactor with only a few percent excess reactivity. This fact, plus the large mean free path for absorption, permits such a reactor to operate with only two control rods. To maintain a high neutron energy, moderating materials are avoided as the coolant; therefore, water and normal organic coolants are not used. Sodium is used, although other liquid metals might be considered, as is indicated in Report ANL-4312. Because sodium boils at $1,620^{\circ} \mathrm{F}$, a reactor can be operated at high temperature, with low pressure, thereby providing a means of minimizing the cost of the heat transfer system. The high coolant temperature that can be used provides a means of attaining a high cycle efficiency. Its high conductivity, reasonable specific heat, and its low cost of only 40 cents per quart make sodium a good heat transport medium. It does react with moist air and water, and these factors must be taken into account in design. So- dium becomes radioactive and, therefore, several feet of shielding is required for the primary system. In order to prevent the release of radioactivity, in case of a rupture of a steam generator tube, an intermediate link is used.

Because the cross section of fissionable material is only several times that of fertile material, the equivalent enrichment of the core material of 10 percent must be used. In order to minimize inventory charges and to attain a short doubling time, fast reactor cores are usually made small. The initial fuel loading for the Enrico Fermi reactor is only 2.5 feet in diameter by 2.5 feet high. To achieve the high power density which results from the use of small cores, the fuel elements are finely subdivided. The size is the equivalent of about one-sixth-inch diameter rods. In this type of reactor, the fuel element lifetime is only limited by the effect of irradiation damage or swelling on heat transfer and by the release of radioactivity to the coolant. As a result, high burnup is sought. When high burnup or cheap reprocessing and refabrication is achieved, very low fuel cycle costs can result. For example, the achievement of a burnup ${ }^{1}$ of 25 percent in a ceramic system makes a fuel cycle cost of around $1 \mathrm{mill} / \mathrm{kw}$ hr attainable.

To simplify the presentation on the fast reactor, a fuel cycle using uranium fertile material and plutonium fuel is described. The fast reactor can be operated so that it will breed using $\mathrm{U}^{235}, \mathrm{Pu}$ or $\mathrm{U}^{233}$ fuel, and using either $\mathrm{U}^{238}$ or thorium fertile material. The mechanical design, thermal operating conditions and heat transport systems for these different fuel and fertile material are the same. The fuel elements may be different.

\footnotetext{
${ }^{1}$ Burnup as used here means the percent of total $\mathrm{Pu}$ and $\mathrm{U}$ atoms in the fuel which have fissioned.
} 


\section{OBJECTIVES}

Simply stated, the objective in developing the fast reactor is to achieve economic power by burning a large fraction of the source uranium.

\section{Closed Fuel Cycle}

The reactor will be operated on a closed fuel cycle to assure high utilization of uranium. Therefore, the fuel feed is assumed to be natural (or depleted) uranium. This material is continuously recycled until it is essentially all burned. The equilibrium fuel fed to the core is alpha and gamma active because of the $\mathrm{Pu}^{240}$ and $\mathrm{Pu}^{241}$ present, even if complete decontamination is used. Therefore, at least glove boxes are required in handling fuel elements, and shielding is needed for handling subassemblies. Beyond the material required to get started, the fast reactor is free from the need of a separate source of plutonium or $\mathrm{U}^{235}$ from an isotope separations plant and requires only a very small feed of uranium.

\section{Low Fuel Cycle Cost}

For fuel cycle cost, the target is 2 mills/ $\mathrm{kw} \mathrm{hr}$ by 1968 and under $1 \mathrm{mill} / \mathrm{kw} \mathrm{hr}$ by 1975 . The potential cost is lower than this. Such low-cost fuel would make possible the use of nuclear energy as the prime supply of energy, whether it be for lighting, heating homes, or making steel. It is pointed out that the burnups required to achieve low fuel cycle costs have been achieved; however, they must be demonstrated under fast reactor operating conditions.

The significant characteristics of the fuel and blanket elements being considered and the objectives in their development are summarized:

(1) Uranium-plutonium alloy fuel elements similar to the pins used in EBR-II. The alloying material would be nonvolatile fission products that would remain as a result of partial decontamination, and other additives, such as molybdenum, added to improve irradiative stability at elevated temperature. This type of fuel element is of interest because it can be operated at high power density, giving a good breeding ratio and short doubling time. Furthermore, the fuel can be reprocessed by simple pyrometallurgical techniques, holding promise of a cheap fuel cycle.

(2) Ceramic fuel element, such as mixed oxides of uranium and plutonium and also separate oxides of uranium and plutonium. These are of interest because they can be operated at high temperature and reasonable power density and because of their potential to accommodate local fission product damage. Because of the possible difficulty in fabricating the small diameter pin elements required for acceptable doubling time of the oxide element, alternate designs, such as "radiator-type," should be considered.

(3) Cermet fuel elements of a dispersion of plutonium oxide or other ceramic body in a matrix of fissile alloy material. The matrix should be capable of operating at high temperature and of restraining the growth of the dispersed material.

(4) Blanket elements. In general the power density in blanket elements is much lower than in the fuel elements, and the concentration of fuel is low. Blanket elements are, therefore, much cheaper to fabricate than fuel elements. Development work on fuel elements for thermal reactors may only require slight extension to apply to these elements. Designs capable of operating to a buildup of the order of 4 percent of fuel atoms is desired to minimize cycle losses. 


\section{Low Capital Cost}

For the 1968 target, the features of the sodium-cooled fast reactors that characterize its economic potential must be more fully exploited. The major objective to date has been to demonstrate the satisfactory operation of prototype plants rather than the full utilization of their economic features. The short-range objective is to evolve plants whose capital cost will not be more than 15 percent higher than conventional coal plants by 1968 . Preliminary studies indicate that this is possible because of some of the features of sodium-cooled fast reactors; some of these are :

(1) The use of sodium as a coolant makes possible the production of steam at, or higher than, the conditions achievable in a conventional plant. Thus, a high electrical output is achievable for a given thermal reactor rating.
(2) Cheap materials can be used: The small absorption of structural material gives a wide selection of reactor materials. The noncorrosive nature of sodium also permits the choice of system materials based on their high temperature mechanical properties.

(3) Low pressure operation of the primary and secondary loops makes possible the use of thin-walled vessels.

(4) The ability to operate with a high temperature rise and with a high temperature drop through exchangers and with high hent transfer coefficients minimizes the heat transport equipment, in spite of the fact that an intermediate link system is used.

For the 1971 objective, new reactor concepts should be developed. 'The objective is to develop plants whose capital costs are equal to or less than conventional plants. To do this, reactors, such as a paste-fuel reactor or an evaporatively cooled, binary fluid reactor, should be investigated. 


\title{
GENERAL RESEARCH AND DEVELOPMENT
}

\author{
(Completed and Under Way)
}

\section{General Physics Features of Fast Reactors}

The neutron energy range of greatest interest to the fast reactor designer is a very wide one, extending from about $50 \mathrm{Kev}$ to several $\mathrm{Mev}$. In this energy range absorption cross sections for almost all materials of interest are about two orders of magnitude smaller than in the case of thermal neutrons. For example, the fission cross section of $U^{235}$ is 582 barns for thermal neutrons but only 1.5 barns for $0.2 \mathrm{Mev}$ neutrons. Likewise a comparison of the fission product cross-section for the two energies shows 77 barns per fission for the thermal case but only 0.07 barn per fission for the $0.2 \mathrm{Mev}$ case.

The value of a (alpha), the capture-to-fission ratio of fissile material is of great importance to breeders. The following table illustrates approximately some of the important features of the variation of alpha with energy:

\begin{tabular}{|c|c|c|c|}
\hline Energy & $U^{2 s s}$ & Puess & $U^{* s s}$ \\
\hline Thermal _._- & 0.18 & 0.42 & 0.12 \\
\hline $10^{2} \mathrm{er}$ & .52 & .72 & .12 \\
\hline $10^{3} \mathrm{er}$ & .43 & 6 & -- \\
\hline $10^{5}$ er & .23 & .28 & .05 \\
\hline $10^{8} \mathrm{ev}$ & .10 & .05 & \\
\hline
\end{tabular}

The value of alpha for $\mathrm{Pu}^{239}$ is not well known below $0.2 \mathrm{Mev}$ and reported values differ by factors of two for energy regions where this property is of great importance. The flat and low characteristic of alpha for $\mathrm{U}^{233}$ over a wide range of energy is of considerable interest.

With appropriate design a very appreciable fraction of the fissions in fast reactors can be made to occur in $\mathrm{U}^{238}$ or in $\mathrm{Th}^{232}$; for instance, in the Enrico Fermi reactor about 15 percent of all fissions occur in $\mathrm{U}^{238}$. This feature is of importance since it permits the direct use of fertile material as well as producing neutrons to en- hance the breeding characteristics of the reactor.

In fast reactors fueled with $\mathrm{U}^{235}$ the effective delayed neutron fraction is slightly less than in $\mathrm{U}^{235}$ fueled thermal reactors since the delayed neutrons have somewhat less reactivity importance due to their inability to cause fission of $\mathrm{U}^{238}$. The large number of fissions which can be caused to occur in $\mathrm{Th}^{232}$ or in $\mathrm{U}^{238}$, which have larger delayed neutron fractions than $\mathrm{U}^{233}$ or $\mathrm{Pu}^{239}$, result in an effective delay fraction in fast reactors larger than that in thermal reactors in cases where either $\mathrm{Pu}^{239}$ or $\mathrm{U}^{233}$ is the fuel.

The average neutron lifetime for all the fast reactors is not appreciably different than that for thermal reactors, being about 0.1 second. The prompt lifetime, however, is appreciably less, being of the order of $10^{-7}$ second as compared to values in thermal reactors ranging from $10^{-3}$ to $10^{-5}$ second.

In fast reactors local inhomogeneities are not important due to the long mean free path of fast neutrons as compared to that in certain thermal reactors.

\section{Physics Experiments and Calculations}

Cross section data.-Total cross sections are generally based on those reported in BNI,-325 but modified by transport approximations. Scattered neutron angular distributions, elastic and inelastic, are obtained from various sources $(1-15,-33,-67,-100,-109)$.

Fission cross sections are usually based on BNL-325. Neutron yields are a modification of measurements (1-111) and calculation (1-112).

Parasitic capture cross sections are obtained from BNL -325 , recent work by Diven (1-53) 
and from Zero Power Reactor III (ZPR-III) experiments (1-45). Radiative capture cross sections of primary fissionable material are based on EBR-I experiments (1-102) and other measurements (1-53).

Inelastic cross sections for lighter elements are generally based on known energy level measurements (1-115). Some inelastic cross section data are obtained from Los Alamos experiments (1-68).

The major problems associated with our current knowledge of fast neutron cross sections are those of precision and difficulty of experimental determination. Many pertinent cross sections have been measured but not with the precision needed by reactor design groups. Other cross sections have defied experimental attempts at determination. Theoretical methods give qualitative results but generally with appreciably less precision than successful experiments.

Papers submitted to the 1958 Geneva Conference more or less summarize the better known pertinent experimental results. Since the conference, most of the pertinent activity in this field may be summed up by more capture cross section determinations, some additional angular distributions and some efforts at determining neutron yield per fission, all as a function of neutron energy.

Important cross sections requiring improved precision or a first measurement include:

(1) Low energy inelastic scattering in $\mathrm{U}^{238}$.

(2) Inelastic scattering in thorium.

(3) Alpha of $\mathrm{Pu}^{239}, \mathrm{U}^{235}$ and $\mathrm{U}^{233}$, particularly below $200 \mathrm{kev}$.

(4) Capture in $\mathrm{U}^{238}$ below $500 \mathrm{kev}$.

(5) Fission in $\mathrm{Pu}^{241}$.

(6) Capture in $\mathrm{Pu}^{240}, \mathrm{Pu}^{241}, \mathrm{Pu}^{242}, \mathrm{U}^{234}$.

(7) $v(\mathrm{E})$ for all fissionable isotopes.

(8) Capture and inelastic scattering in potential structural, alloying and coolant materials, where not fully measured.

Critical experiments.-A large number of elementary fast critical assemblies with a high core density have been operated at the Los
Alamos Scientific Laboratory (LASL) (1-44, $-62,-63,-64,-65)$.

(1) Godiva - sphere - unreflected - 93.5 percent enriched with $49 \mathrm{~kg}$ of $\mathrm{U}^{235}$.

(2) Topsy-sphere-21 cm natural uranium reflector-93.5 percent enriched core$16 \mathrm{~kg} \mathrm{U} \mathrm{U}^{235}$.

(3) Jezebel-sphere-unreflected plutonium core-16.45 kg. $\mathrm{Pu}$.

(4) Popsy-sphere-21 cm natural uranium reflector-plutonium core- $5.79 \mathrm{~kg} \mathrm{Pu}$.

(5) Jemima-L/D 0.58-unreflected-53.6 percent enriched with $89.5 \mathrm{~kg} \mathrm{U} \mathrm{U}^{235}$.

(6) Jemima-L/D 1.00-unreflected-37.7 percent enriched with $101.0 \mathrm{~kg} \mathrm{U} \mathrm{U}^{235}$.

(7) Jemima-L/D 1.08-unreflected-29 percent enriched with $123 \mathrm{~kg} \mathrm{U^{235 }}$.

(8) $\mathrm{U}^{233}$ - sphere-unreflected core with

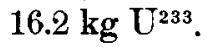

The data from these assemblies furnish a foundation for predicting behavior of more complex systems. Absorption and transport cross section data, $\mathrm{U}^{235}$ to $\mathrm{U}^{238}$ fission rates, deleyed neutron yields, influence of shape or size, effect of composition perturbations on critical size, reflector savings, and prompt neutron lifetimes, are some of the useful data obtained.

The British fast critical assemblies are Zephyr and Zeus (1-3 through 1-7). Zephyr is a plutonium fueled assembly used to extend existing data and to obtain more knowledge of plutonium phenomena. Zeus is a $\mathbf{U}^{235}$ fueled mock-up of the Dounreay fast reactor.

The ZPR-III critical assembly at National Reactor Testing Station, Idaho (1-44 through $1-46$ ) is a flexible dilute core assembly permitting investigation of a wide range of sodiumcooled fast reactor designs. At least $12 \mathrm{ZPR}-$ III assemblies with a $\mathrm{U}^{238}$ to $\mathrm{U}^{235}$ ratio ranging from 0 to $7, \mathrm{~L} / \mathrm{D}$ of 0.88 to 1.04 , graphite composition from 0 to 0.734 , and various critical masses have been constructed.

Comparison of several different means of calculating critical masses for various assemblies of different $\mathrm{U}^{238}$ to $\mathrm{U}^{235}$ dilution ratios indicates that though the predictions throughout the entire range may not be of great accuracy 
the correlation is good and useful in obtaining a realistic critical mass estimate. For a 3 to 1 ratio and a $0.88 \mathrm{I} / \mathrm{D}$ the measured critical mass of $151.9 \mathrm{~kg}$ [ $^{235}$ compares with $155 \mathrm{~kg}$ calculated, but with a 7 to 1 ratio and a 0.88 $\mathrm{L} / \mathrm{D}$ the measured $240.6 \mathrm{~kg}$ compares to $292 \mathrm{~kg}$ calculated. The experiments indicate that predictions of fission ratios, in general, are accurate.

Central material replacement experiments utilizing $\mathrm{Pu}$ and $\mathrm{I}^{233}$ indicate that calculated reactivity effects of replacement check well with the experimental results, considering the lack of detailed cross-section information. These replacement experiments provide nuclear behavior data of $\mathrm{Pu}$ and $\mathrm{U}^{233}$ since dilute critical assemblies of these two materials are not available. For example, the experiments indicate that the calculated quantity $(v-1-a) \sigma$, the relative effectiveness, in barns of fissionable material, averages 3.34 for $\mathrm{Pu}, 2.06$ for $\mathrm{U}^{235}$ and 3.39 for $\mathrm{U}^{233}$, and is in good agreement with experimental results.

Calculated prompt neutron lifetimes compare well with experimental results using Rossi a measurements except for more dilute systems with softer spectra.

Argonne National Laboratory has done considerable theoretical work, some very preliminary design work, and experimental work to the extent of a series of critical experiments on the fast-thermal coupled reactor. The general objective of such a system is to obtain a prompt neutron lifetime characteristic of a thermal reactor concurrent with the breeding characteristics of a fast reactor. The reactor is essentially a four-region device: A fast core, an inner blanket in which thermal fissions take place, a moderating region surrounding the inner blanket, and an outer blanket surrounding the moderating region.

Engineering of fast-thermal coupled reactor concept has not been carried far enough to allow judgment of its potential, but many of its principal problems are common to those of the simple fast reactor. Others, such as fission product poisoning effect in the thermal region, are unique and as yet not evaluated.

Calculations.-Analysis of fast renctor systems rests on solutions of the Boltzmamn equation (1-106). A solution based on a transport approximation, the Sn method (1-54), is useful for spherical geometry. A second method based on diffusion theory $(1-14,1-41)$ is adequate to describe the nuclear characteristics of large dilute fast breeders. This last method lends itself to separability in simple geometry, and also to digital computation. A third method uses asymptotic calculations (1-41) which can generate multigroup spectra without high speed machines. For a 400-liter metal core the deviation in the critical radius between the $\mathrm{Sn}$ and diffusion methods is 0.016 . For an 800-liter oxide core this deviation is 0.013 . For a similar core but less dense reflector the deviation is 0.020 , indicating diffusion theory neutron leakage is not adequately described.

Analyses for EBR-II indicate that onedimensional analyses give critical masses 10 percent higher than two-dimensional. This is mainly due to reflector nonuniformity and inclusion of nonfertile material. The twodimensional diffusion calculations are adequate for $\mathrm{L} / \mathrm{D}$ ratios from 0.213 to 2.13 as determined by the constancy of $k_{\text {eff }}$ which stayed in a range 0.947 to 0.951 .

Calculated spatial neutron flux variation is well within experimental uncertainties.

Determination of temperature and/or power coefficients must rely first on theory, and finally on the actual reactor, since measurements on zero power reactors are not possible. Some indirect information from material replacement experiments and small perturbations on core geometry can be obtained. Calculation by twodimensional diffusion theory is expensive. Onedimensional nonspherical calculations are not adequate, but multiregion spherical calculations provide satisfactory results for most nonspherical systems. This has been demonstrated in EBR-I Mark III loading $(1-48)$ and EBRII $(8-8,8-30)$. 
The type of multigroup code program used depends on the purpose. Engineering design analysis with fixed dimensions requiring varied compositions for fuel alloy enrichment determination can be obtained from a UNIVAC onedimensional code, with up to 20 groups, and with 6 inelastic transfers. An IBM 704 and a Datatron can also be used. An SNG program (1-54) using an IBM 704 provides for attainment of criticality by varying dimensions, for studies of heterogeneities, and for corrections to diffusion theory calculations (1-45, 1-54).

Two group calculations using a MUG-II UNIV AC program can account for geometric effects. This can also be done by CURE and PDQ programs using IBM 704 machines. The Nick-II-IBM 704 program provides for twodimensional inelastic scattering to more than one group. It also provides for more accurate power distribution analysis. PROD-II using an IBM 650 is used widely and most one-dimensional diffusion theory programs are based on it. The Hobo-IBM 650 program provides for determination of reflector savings, extrapolation distances, and equilibrium spectral effects.

\section{Fuel and Materials Properties}

ANL fuel.-Research at ANL on solid fuel has included investigations on metal and on ceramies (4-56). Most of the irradiations have been on 1.0-inch long and 0.125 - to 0.250 -inch diameter specimens.

Dimensional stability is of prime importance. The growth coefficient is a good index of relative dimensional stability between different materials. This coefficient is defined as:

$$
\mathrm{G}_{1}=\frac{\ln L \phi L o}{\text { fraction of total atoms fissioned }}
$$

Where length changes are small, or where $G_{1}$ varies with burnup the approximation

is used.

$$
G_{1}=\frac{\text { percent length change }}{\text { atoms percent burnup }}
$$

The $G_{1}$ for unalloyed wrought uranium varies from 25 for 0.5 a/o burnup $300^{\circ} \mathrm{C}$. rolled and beta quenched material to 690 for $300^{\circ} \mathrm{C}$. rolled material. Values for some alloys are given in table 1.

The tests indicate that malloyed uranium even with the best known metallurgical treatment is not stable to burmups as low as $2 \mathrm{a} / \mathrm{o}$. The deleterious changes which occur in unalloyed materials at moderate irradiation temperatures are evidenced principally as surface roughening and anisotropic growth. Certain residual alloying additions have been known to greatly refine the grain size in uranium, thus reducing surface roughening. Furthermore, alloying additions can alter the transformation kinetics of uranium so that the effects of preferred orientations resulting from rolling or extruding fabrication procedures may be largely removed by heat treatment. For alphaphase alloys, these heat treatments usually consist of holding the material briefly in the gamma phase, followed by an extended isothermal anneal to permit the alloy to transform completely to alpha. For alloys which can retain the gamma phase on cooling, the preferred heat treatment is usually a quench from the gamma phase, which may be preceded by a homogenizing anneal at gamma temperatures. Both uranium and uranium-base alloys show definite irradiation temperature limitations, above which swelling occurs. Thorium and thorium-uranium alloys show dimensional stabilities which appear to equal those shown by the metallic uranium fuels. Oxide fuels are generally characterized by relatively good stability under irradiation. Pellets of $\mathrm{ThO}_{2}$ with additions of $\mathrm{IO}_{2}$ show negligible dimensional changes after burnups of the order of 1 percent of the metal atoms with central temperatures of $2,000^{\circ} \mathrm{C}$. or more during irradiation.

The pyrometallurgical processing at ANL builds up a group of fission product elements called "fissium" which are difficult to remove economically. A program of testing the U-Fs alloys indicates that the as-cast alloy gave relatively good stability under irradiation when the fissium was gamma quenched. A fabrication process has been delevoped for a relatively sim- 
TABLE 1.- $\mathrm{G}_{\mathrm{i}}$ VALUES FOR SOME ALLOYS

(1) Alpha phase uranium alloys:

(a) U-Cr, 0.1 and $0.4 \mathrm{w} / \mathrm{o} \mathrm{Cr}$

(b) U-Mo, 1 to $3.5 \mathrm{w} / \mathrm{o} \mathrm{Mo}$

(c) U-Pu, 3.7 to $18.7 \mathrm{w} / \mathrm{o} \mathrm{Pu}$

(d) $\mathrm{U}_{3} \mathrm{Si}, 3.8 \mathrm{w} / \mathrm{o} \mathrm{Si}$

(e) U-1.62 w/o Zr casting

(f) U-2 w/o Zr wrought

(g) $\mathrm{U}-1 \quad \mathrm{w} / \mathrm{o}$ and 2 w/o $\mathrm{Zr}$ rolled and annealed.

(h) $\mathrm{U}-5 \mathrm{w} / \mathrm{o} \mathrm{Zr}-1.5 \mathrm{w} / \mathrm{o} \mathrm{Nb} \ldots$

(2) Gamma-phase uranium alloys:

(a) U-3.17 w/o Fissium

(b) U-5 w/o Fissium

(c) U-5 w/o Fissium 2.5 and $7.5 \mathrm{w} / \mathrm{o} \mathrm{Mo.}$

(d) U-20 w/o Pu-5.4 w/o Fissium and $10.8 \mathrm{w} / \mathrm{o} \mathrm{Fis-}$ sium.

(3) Thorium:

(e) U-20 w/o Pu-5.0 w/o Mo

(a) Th-0.1 to 5 w/o U-235

(b) $\mathrm{ThO}_{2}-2.5 \mathrm{w} / \mathrm{o} \mathrm{UO}_{2}$

(c) $\mathrm{ThO}_{2}-10 \mathrm{w} / 0 \mathrm{UO}_{2}$

Burnup, a/o
Up to 0.65
Up to 0.5
Up to 0.84
Up to 0.8
Up to 1.6
N.A.
N.A
N.A.
N.A.
N.A.
N.A to 4.4
N.A
Up to 0.75

$\mathrm{G}_{\mathrm{i}}$
1.5 to 20
10 to 100
-3 to +4 cast 30 extruded
3.8

470 unquenched.

64 quenched.

3 tempered after quenching.

-300 with $20 \mathrm{ppm}$ carbon.

-200 with $400 \mathrm{ppm}$ carbon.

+150 with 4,000 ppm carbon.

150 as swaged.

300 gamma quenched.

5.4 24-hour isothermal transformation at $650^{\circ} \mathrm{C}$.

50 gamma quenched.

-0.1 24-hour isothermal transformation at $650^{\circ} \mathrm{C}$.

-0.1 gamma quenched

2 quenched or slowly cooled

1.8 as cast

3.2 as cast

0.065 to 0.85

0.02

0.02
Note 1

Had large diameter change.

Large diameter changes above $600^{\circ} \mathrm{C}$.

1 Unless indicated to the contrary, all irradiations were carried out at temperatures of less than $550^{\circ} \mathrm{C}$.

Note.-N.A. signifies "not available."

ple injection casting technique for this material. A program of determining the best fissium composition has been in progress. The reference is U-5 w/o Fs. Swelling at $0.5 \mathrm{a} / \mathrm{o}$ burnup and $700^{\circ} \mathrm{C}$. is small. A $\mathrm{Pu}-$ fissium program will be carried out in the same manner as the U-fissium program, beginning in 1960.

APDA-sponsored fuel (4-19, 4-21).Through 1958 approximately 175 specimens have been irradiated in the Materials Testing Reactor (MTR) and 3 full-length pins in the
Argonne Research Reactor (CP-5) in support of the Enrico Fermi plant. The first phase of the program consisted of alloys of $\mathrm{U}-\mathrm{Cr}, \mathrm{U}-\mathrm{Zr}$, U-Mo. The U-5 w/o Cr eutectic alloy did not have radiation stability, and irradiation of $\mathrm{U}-\mathrm{Zr}$ alloy specimens containing $2,2.2,3,5,10$ and 15 percent by weight of $\mathrm{Zr}$ indicated that the radiation stability is inferior to the U-Mo alloys containing $3.5,5,7$ and 10 percent by weight of Mo. U-Mo alloy containing 10 percent Mo was selected as the reference fuel alloy 
for the first two core loadings of the Enrico Fermi reactor. On length Changes, $G_{1}$ values range from 0.4 to 1.1 at temperatures below $1,100^{\circ} \mathrm{F}$. Test results show that fuel pin swelling is not sensitive to irradiation temperatures below $1,100^{\circ} \mathrm{F}$. for U-10 w/o Mo. Post irradiation heating of the reference alloy irradiated below $1,100^{\circ} \mathrm{F}$. and heated for 100 hours at $1,300^{\circ} \mathrm{F}$. resulted in diameter increase directly proportional to the square of the burnup. Post irradiation measurements of density and other physical properties have been conducted on reference specimens irradiated to beyond 2 total a/o burnup. Transformation kinetics have been extensively studied for the reference alloy and indicate that the retained gamma structure of the reference alloy is more stable than the partially transformed or the transformed alpha plus epsilon structures. The radiation stability of the gamma treated reference alloy is good to 2 a/o burnup below $1,100^{\circ}$ F. and to 0.5 a/o burnup below $1,350^{\circ} \mathrm{F}$. Large physical changes, such as swelling or ruptures, have occurred at less than $1.5 \mathrm{a} / \mathrm{o}$ burnup when irradiated above $1,100^{\circ} \mathrm{F}$. Further work is continuing to determine the threshold fission rate necessary to maintain the reference alloy in the gamma phase for temperatures of $800^{\circ} \mathrm{F}$. to $900^{\circ} \mathrm{F}$.

The fuel fabrication program for the Enrico Fermi reactor has gone through three experimental phases. In the first phase the direct casting of $\mathrm{U}-5 \mathrm{w} / \mathrm{o} \mathrm{Cr}$ alloy and the direct casting of $\mathrm{C}-2 \mathrm{w} / \mathrm{o} \mathrm{Zr}$ alloy were terminated because of radiation stability, the undesirable restrictive requirements of the direct casting procedure, and lack of reprocessing technology. Sodium bonding of the $\mathrm{U}-\mathrm{Cr}$ and $\mathrm{U}-\mathrm{Zr}$ elements was also attempted and discontinued because of the poor irradiation instability of these alloys. Low alloys of molybdenum and niobium were included as well as eutectic alloys of chromium. Fabrication of core elements included rolling, extrusion, drawing, hot mold casting, lost wax casting, and hot pressing. The irradiation results on these alloys were not satisfactory.
In the second phase of the program heat fluxes were reduced and more emphasis placed on radiation stability. A $\mathrm{I}-2 \mathrm{w} / \mathrm{o} \mathrm{Zr}$ alloy was fabricated as a metallurgically bonded coextruded pin and irradiated. Dimensional stability was poor.

The third phase tests indicated that stabilized alloys of the U-Mo system of $91 / 2$ to $131 / 2$ percent $w / o$ Mo had radiation stability superior to previous alloys. The decision was made in Iecember of 1955 to proceed with a U-10 w/o Mo metallurgically bonded pin. Extensive fabrication experimentation was conducted to determine the most feasible method of fabricating the present reference pin.

Work has been done on uranium-molybdenum alloy- $\mathrm{CO}_{2}$ dispersions. Fabrication procedures, including the production of base-alloy powder by a hydriding technique, were established and tensile-strength and thermal-expansion data were obtained for U-3.5 w/o Mo plus $27 \mathrm{w} / \mathrm{o} \mathrm{UO}_{2}$ dispersion plates. A technique for powdering $\mathrm{U}-10 \mathrm{w} / \mathrm{o}$ Mo alloy by hydriding was developed and unclad U-10 w/o Mo plus 27 w/o $\mathrm{UO}_{2}$ dispersion plates were fabricated for irradiation in the MTR. Duplicate sets of unclad specimens were irradiated to approximately 1 and 2 total a/o burnups at calculated center-line temperatures of $650^{\circ}$ to $800^{\circ} \mathrm{F}$. Neither the $\mathrm{UO}_{2}$ fuel dispersion nor the U-10 w/o Mo matrix showed any gross damage attributable to irradiation. Density values, calculated from measured dimensions, decreased an average of 1.5 percent per a/o burnup. Dispersion plates of $\mathrm{U}-10 \mathrm{w} / \mathrm{o}$ Mo plus $27 \mathrm{w} / \mathrm{o}$ $\mathrm{UO}_{2}$ were successfully clad by gas-pressure bonding with both molybdenum and niobium; however, no clad specimens were irradiated.

In September 1956, the APDA Core II program to develop and study improved reactor cores was started with Battelle Memorial Institute because it was known that the present core would result in very high operating costs for the Enrico Fermi Atomic Power Plant. The initial aims of the program consisted of three separate phases: (1) design and fuel cycle cost evaluation, (2) research and devel- 
opment, and (3) production of one full or partial core loading for test purposes in the Enrico Fermi reactor. Several major revisions to the original ground rules were considered, and this work, constituting Phase I of this program, was completed in July 1958.

The specific objectives of this work were twofold: (1) To develop an inexpensive fuel cycle for advanced fast breeder power reactors and (2) to produce a low-cost fuel cycle for the Enrico Fermi reactor. The scope and schedule of the program were established in order to provide the sixth core loading for the Enrico Fermi reactor. Uranium 235 was assumed to be the fissionable fuel material, the reactor size was equivalent to a Fermi I 139-subassembly core, all reprocessing costs are assumed to be those in the Power Reactor Development Company (PRDC)-AEC contract or similar, and the blanket design was assumed to be the same as the present sodium bonded blanket. The emphasis in Phase I was on fuel element design, materials evaluation and fuel cycle cost studies to determine the optimum economic core design parameters. All core physics calculations were performed by the APDA Nuclear Engineering Section. Three reports were required because of successive changes in the ground rules of fuel cycle comparisons. The first report was prepared for an evaluation of core fuel systems of a second Fermi reactor for $616 \mathrm{Mw}$ core heat output with a 139 -subassembly core size limitation, plutonium revenue at $\$ 44$ a gram and an optimistic estimate of reactor plant costs. The Addendum I report summarized core fuel cycles at $300 \mathrm{Mw}$ electric output with plutonium revenue at $\$ 30$ per gram. The Addendum II report showed a comparison of fuel cycle costs for a new reactor with core size variable to be economically optimized for each core material considered. The requirement that the reactor have a conversion ratio greater than one was eliminated in the last revision to the ground rules, since for $\mathrm{U}^{235}$-fueled fast reactors, economic considerations would determine what the conversion ratio should be.
While the fuel cycle cost studies were made on the basis of a new, conventionally financed power reactor with 12.83 percent fuel inventory charges, APDA calculations indicate that the core fuel system thus selected would also be the least expensive for Fermi I operation.

Evaluation of potential fuel systems under the first Phase I ground rules led to the following materials and designs as showing the most promise :

(1) Alloy fuels-U-10 w/o Mo or gammaphase-type alloy clad in zirconium in a flat plate subassembly design.

(2) Ceramic fuel-90 percent dense $\mathrm{UO}_{2}$ pellets in sodium-filled stainless steel pins. A parallel plate design utilizing a stainless steel radiator-type assembly was economically attractive but would require release of fission gases to the main coolant stream. As a result, this design would require development work beyond the scope of the original program at Battelle.

(3) Dispersion or cermet fuels-A $30 \mathrm{v} / \mathrm{o}$ dispersion of $\mathrm{UO}_{2}$ in U-10 w/o Mo or gamma-phase-type alloy, zirconium clad, in a flat plate subassembly design.

In the portion of the study concerned with revision 2 (addendum I) of the ground rules, the same fuel systems as given above were considered. Uranium monocarbide (UC) was considered both as a ceramic fuel and as a dispersed fuel in a U-10 w/o Mo matrix. Although under the revised ground rules the economics were not as favorable as under the original rules, Battelle Memorial Institute (BMI) felt the cermet system was the most promising.

When core size and conversion ratio limitations were removed, it was possible to consider cermets with nonfuel matrices. The cermet UC dispersed in Inconel $\mathrm{X}$ was considered to be very promising. It and $\mathrm{UO}_{2}$ pins were recommended as the fuel systems for future development.

Table 2 shows a comparison of the six fuel cycles of primary interest. The four ceramic systems using $\mathrm{UO}_{2}$ or UC in pin or plate geom- 
TABLE 2.-APDA CORE II FUEL SYSTEMS

\begin{tabular}{|c|c|c|c|c|c|c|}
\hline & $\underset{\text { plates }}{\mathrm{UO}_{2}}$ & $\begin{array}{c}\text { UC } \\
\text { ceramic } \\
\text { plates }\end{array}$ & $\begin{array}{l}\text { UC } \\
\text { ceramic } \\
\text { pins }\end{array}$ & $\underset{\text { pins }}{\mathrm{UO}_{2}}$ & $\begin{array}{c}\mathrm{U}-10 \text { w/o } \\
\text { Mo alloy } \\
\text { plates }\end{array}$ & $\begin{array}{l}\mathrm{UC} \text { in } \\
\text { Inconel } \mathrm{X} \\
\text { cermet } \\
\text { plates }\end{array}$ \\
\hline Reactor power, Mw & 281. 2 & 278.0 & 276. 2 & 277. 2 & 279. 9 & 281. 2 \\
\hline Load factor, percent & 75 & 75 & 75 & 75 & 75 & 75 \\
\hline Core diameter and length, inches & 49. 8 & 49. 8 & 62.3 & 62.3 & 43. 5 & 43. 5 \\
\hline Sodium temp, of-In & 450 & 550 & 600 & 600 & 550 & 550 \\
\hline Sodium temp, of-Out & 800 & 900 & 950 & 950 & 900 & 900 \\
\hline Number plates or pins/subassembly & 29 & 10 & 784 & 784 & 27 & 18 \\
\hline Plate thickness or pin diameter, inches . . & 0.062 & 0. 250 & 0.146 & 0.146 & 0. 066 & 125 \\
\hline Critical mass, $k g-25 \ldots$ & 871 & 1,400 & 1,850 & 1,533 & 1,038 & 550 \\
\hline Conversion ratio-Core $\ldots$ & 0.43 & 0.646 & 0.649 & 0.57 & 0.56 & .13 \\
\hline Conversion ratio-Blanket & 0.61 & 0.508 & 0. 446 & 0. 47 & 0.58 & 79 \\
\hline Burnup: & & & & & & \\
\hline$U^{235}$ atom percent $\ldots$ & - 58.5 & 94.2 & 95.0 & 77.5 & 23. 4 & 84. 0 \\
\hline Total atom percent & 3. 95 & 6. 15 & 6.95 & 4. 23 & 2. 62 & 3. 0 \\
\hline Core life, days & 769 & 1810 & 2796 & 1846 & 354 & 793 \\
\hline Costs-Mills $/ \mathrm{kw} \mathrm{hr:}$ & & & & & & \\
\hline Fixed $b$ & 7. 871 & 7. 970 & 8. 025 & 7. 994 & 7. 911 & 7. 871 \\
\hline Core fabrication & .164 & .054 & .064 & .097 & 269 & .136 \\
\hline Fuel cycle. & .449 & .201 & .178 & .363 & 1. 108 & .231 \\
\hline New fuel & 2. 873 & 2. 607 & 2. 599 & 2. 789 & 2. 774 & 2. 916 \\
\hline Blanket cycle & .816 & .796 & .696 & .679 & .825 & .899 \\
\hline Fuel inventory & 1. 133 & .926 & 1. 439 & 1. 470 & 2. 046 & .660 \\
\hline Gross costs $b$ & 13. 306 & 12. 554 & 13. 001 & 13. 392 & 14. 933 & 12. 713 \\
\hline 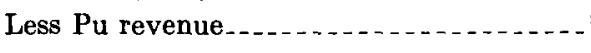 & 5. 231 & 5. 389 & 5. 330 & 5. 165 & 5. 174 & 4. 717 \\
\hline Net costs $b \ldots$ & .8 .08 & c 7.17 & 7. 67 & 8. 23 & 9. 76 & 8. 00 \\
\hline
\end{tabular}

- Not an optimized design. Net power costs for this system should be only slightly higher than the UC ceramic plates.

b The fixed changes used were for a $300 \mathrm{M}$ we plant. Net power costs lor each of the eases presented should be reduced by 0.4 to $0.6 \mathrm{mills} / \mathrm{kw}$ hr.

- Scrap used fuel after $\mathrm{Pu}$ removal.

etry have consistently indicated promise of lowcost power production. The alloy plate system is included as a basis for comparison, not because of its economic equality. The UC-Inconel $\mathrm{X}$ cermet also gives promise of being a low fuel cycle cost fuel.

Burnup of each fuel material is the most significant parameter in achieving economy of fuel cycle performance. The alloy system burnup is based on current expectations of best performance at 3.0 percent maximum burnup at $1,200^{\circ}$ F. The burnup of the UC-Inconel X system is determined from extrapolations of the $\mathrm{UO}_{2}-\mathrm{SS}$ cermet irradiation stability assuming that the transverse tensile strength is the limiting factor.

Fixed costs are based on Fermi II studies. Fabrication costs are for the period 1965-85, and are the best estimates of BMI. These costs include $\mathrm{UF}_{6}$ conversion to fuel material and complete fabrication costs. Fuel cycle costs are those of core reprocessing, core plutonium metal conversion, and conversion of enriched uranyl nitrate to $\mathrm{UF}_{6}$. Fuel inventory costs are based on 12.83 percent fixed charge for inpile and 10-month out-of-pile inventory.

Net costs indicated are useful only for comparative purposes at this time, because of the 
large number of assumptions made in the study. Fast oxide breeder program.-The fast oxide breeder (FOB) was initiated by the Knolls Atomic Power Laboratory (KAPL).

The FOB fuel element consisted of a type 347 stainless steel tube 0.200 -inch I.D. with a wall thickness of 0.015 inch, 42 inches long enclosing a 65 percent dense pin of mixed oxides of $\mathrm{Pu}$ and $\mathrm{U}$. The voids in fuel material and 0.0015 inch annulus between fuel and clad were to be filled with helium during fabrication. The fission gases released by the fuel material were to be contained under pressure in the fuel element voids and inside the cladding tube. There is some question whether the proposed fuel element could operate at the design heat generation rates without melting during rapid reactor transients of small magnitude. The irradiation test work indicates that sintering takes place in the center of the pin when it is raised gradually to operating temperatures, producing a central void, but increasing thermal conductivity of the higher density sintered layer. Since thermal conductivity of this material is not well established, it is not clear if fuel melting would result during a, say, 50 percent rapid reactor overpower transient. The effects of fuel melting in the reactor were not studied, but it is now believed that some can be tolerated.

The cladding thickness was determined to contain 100 percent fission gas released from the fuel up to 50 percent burnup of the original plutonium loaded. Fission gas release rate has not been determined, and it must be known to properly design the fuel elements and reactor cover gas system.

The FOB program did not include such design studies as effect of core composition on power costs, subassembly bowing problems, coolant pressure drop effects on subassembly design or reactor vessel components.

Reactor safety studies and reactivity coefficients apparently were not studied, undoubtedly because of the lack of reliable data to depend on for fuel behavior under irradiation. A simple experiment was devised and com- pleted to predict fuel expansion coefficients under rapid increases in fuel material temperature $\left(500^{\circ} \mathrm{C}\right.$. per second). Measurements recorded were indicative of thermal expansion rates, but were accurate to a factor of two or three. Effects of cracking in elements could not be evaluated.

The FOB reactor design studies consisted only of enough information to allow them to identify the development problems with the mixed oxide fuel, and then they concentrated major effort on the fuel cycle development problems.

Fuel cycle development was the major effort of the FOB program. A core fuel cycle process was devised based on a minimum number of operations of a simple nature, and then the group set out to prove that this process would work. Part of the process operations were demonstrated in full size equipment constructed at the laboratory. The dissolution of mixed oxides of $\mathrm{Pu}$ and $\mathrm{U}$ produced by this process was established after irradiations in MTR.

Full-scale equipment was built to chop fuel elements, dissolve them in $\mathrm{HNO}_{3}$, and aqueously separate the fission products. This equipment used substitute fuel elements to demonstrate process operation feasibility. Irradiation specimens manufactured were made in hot cell operations in small batches starting with the solvent extraction column products (uranium and plutonium nitrates), precipitated, filtered, dried and reduced to the mixed crystal state. Specimens were formed by compacting and sintering into pellet shapes. The extrusion equipment was built and tested a few times to produce long pins.

Feasibility of the chopping and dissolving operations was established. The radiation chemistry analysis of the solvent extraction operations indicates good promise of success, the only problem remaining being that a second stage extraction process or longer cooling period might be required. Conversion from the nitrate products of solvent extraction to the mixed oxide crystal is a feasible process, subject to investigation of process quality control. 
Uncompleted fabrication development problems are mainly concerned with methods of making straight pins and achieving control of density of the finished product. These were not considered insurmountable problems.

Four irradiation experiments have been conducted to date in this program. The fuel elements for these tests (except irradiation test (KAPL 26-3)) were made with 0.250 -inch O.D., 0.1875 -inch I.D. type 347 stainless steel tubes filled with 1 inch of oxide pellets and one-half-inch long end plugs of $\mathrm{MgO}$. The end closure was welded on with one-half atmosphere of helium in the tube. The elements were inserted in a NaK-filled stainless steel capsule. The capsule was inserted into an $\mathrm{Al}$ container with $\mathrm{MgO}$, thermocouples, calrod heaters, and during reactor operation helium surrounding the capsule. The calrod heaters were designed to keep the $\mathrm{NaK}$ bath at the desired temperature.

The first irradiation test (KAPL 26-1) was conducted with $\mathrm{NaK}$ temperature above $600^{\circ} \mathrm{C}$., specific power $=3,600 \mathrm{kw} / \mathrm{kg}$ of $\mathrm{Pu}$ and to a depletion of 5 percent of the $\mathrm{Pu}$ (about onequarter percent total atoms). This test produced a central void, a sintered annulus around the void and some radial cracking.

The second irradiation test (KAPL 26-2) was similar in conditions of operation except $\mathrm{Pu}$ depletion was 35 percent (about 2 percent total atoms) and $\mathrm{NaK}$ temperature was near $300^{\circ} \mathrm{C}$. This test produced about the same results as KAPL 26-1, but more radial cracks were observed.

The third irradiation test (KAPL 26-3) was designed to eliminate the void observed in the first two tests. A three-eighth-inch O.D., 0.030inch wall stainless steel tube was filled with lead. A 0.1875-inch diameter hole was then drilled in the lead and the oxide pellets loaded as before. As was intended, the lead melted in operation to form a good thermal bond, but the oxide fuel floated partly above the lead surface. This element was irradiated to 5 percent depletion of $\mathrm{Pu}$ (about one-quarter percent total atoms). The results were unusual in that no sintering occurred, although pronounced cracking resulted and the oxide was found to be quite friable.

The fourth irradiation test (KAPI, 39-1) was conducted with $\mathrm{UO}_{2}$ substituted for the mixed oxides previously used. The purpose of this test was to determine whether spalling and settling occurred as a result of void formation. The 20 percent enriched, 86 percent dense $\mathrm{UO}_{2}$ fuel was prepared by extrusion with a Ceramul $\mathrm{C}$ binder, dried, fired and sintered for one hour at $1,600^{\circ} \mathrm{C}$. in hydrogen. This capsule was cycled in an MTR cycler 50 times in a 3 -week cycle. $U^{235}$ depletion was less than 5 percent (about one-quarter percent total atoms); a central void formed equal to about 11 percent of the original fuel volume. No settling of the fuel occurred.

In none of the above experiments was any cladding change observed; fission gas quantities were not measured.

Other materials. ${ }^{2}$ - The reactor vessel for the Fermi plant has been designed to withstand an integrated neutron exposure that is within the range for which experimental information exists. The expected flux exposure of the reactor vessel in a 20 -year lifetime and the available experimental data are given in table 3 . Although these data indicate no serious effects for exposures at ambient temperatures and energies, a continual check on the mechanical and physical properties will be kept by means of surveillance tubes containing control specimens located in areas exposed to high radiation. The specimens were cut and machined from the same sheet, plate, or bar as the section under scrutiny and will be removed at periodic intervals so that a complete and comparative service history will be available.

Intensive tests at ANL, KAPL, Atomics International, and Babcock \& Wilcox on type 304 stainless steels and low-alloy steels indicate that, for the uses intended in the Fermi plant, these steels are more than adequate to do their jobs. Mass transport and corrosion loop tests

\footnotetext{
${ }^{2}$ A discussion of $\mathrm{UO}_{2}$-stainless steel dispersion fuel elements is given under the heading Fuel and Material Properties.
} 
TABLE 3.-RADIATION OF STABILITY CONSIDERATIONS USED IN THE REACTOR VESSEL DESIGN

\begin{tabular}{|c|c|c|}
\hline \multirow[b]{2}{*}{ Parameter } & \multicolumn{2}{|c|}{ Integrated flux, nvt } \\
\hline & Exposure and spectrum & $\begin{array}{c}\text { Fast, after } \\
10 \text {-year } \\
\text { operation }\end{array}$ \\
\hline $\begin{array}{l}\text { Maximum exposure data available: } \\
\text { No serious deleterious effects noted: } \sim 5.5 \text { years in MTR } \\
\text { EBR-1 core container and flow separator } 2 \\
\text { Calculated exposure of vessel wall } 3 \\
\text { Calculated exposure of spot in blanket } 12 \text { inches from core } \\
\left(2.6 \times 10^{14} \mathrm{nv}\right) \text {. }\end{array}$ & $\begin{array}{l}3.8 \times 10^{22}\left((>100 \mathrm{ev})^{*} \ldots\right. \\
2.0 \times 10^{21}(370 \mathrm{kev})\end{array}$ & $\begin{array}{l}6 \times 10^{21} \\
7 \times 10^{22}\end{array}$ \\
\hline
\end{tabular}

*The nvt $>100 \mathrm{kv}$ is estimated to be $10^{22}$.

1 M. R. Bartz, "Effects of Irradiation on MTR Materials," Proceedings of the Conference on Radiation Effects, TID-7515 (pt. 1), U.S. Atomlc Energy Commission, 1956.

2 R. E. Bailey and M. A. Silliman, "Effect of Fast Neutron Irradiation on the Properties of Stainless Steel," Symposium on Radiation Effects to Materials, vol. III, American Society for Testing Materials, June 1958 (to be published).

a Based on half time at $300 \mathrm{Mw}$ and half time at $430 \mathrm{Mw}$ with 75 percent plant factor.

indicate that where low alloy steels of $21 / 4$ percent chromium are used and temperatures are below $850^{\circ} \mathrm{F}$. decarburization is of no consequence.

Corrosion tests of stressed and unstressed specimens of type 304 stainless steel and $21 / 4$ percent Cr, 1 percent Mo ferritic steel in static and dynamic sodium with up to 6 percent addition of sodium hydroxide have not shown any evidence of stress corrosion cracking. Proper design and careful control of materials will preclude such cracking.

Intensive tests at KAPL, ANL, Detroit Edison's engineering research department, and Allis-Chalmers on the galling and diffusion bonding of different materials in sodium indicate that hard surfaced materials must be used where undue pressures and high temperatures can exist. Nitrided, stellited or colmonoy surfaces are used in the Fermi system where mating parts are subject to high temperatures and pressures $(4-3,4-20)$.

Various shielding materials have been investigated. Serpentine rock up to $800^{\circ} \mathrm{F}$. has good long-time water retention as determined by tests and is being used in the Fermi plant in the plugs of the intermediate heat exchangers. Irradiation tests made on calcium borate insula- tion and shielding, used around sodium piping near the reactor, indicate that there are no apparent adverse effects on the load supporting properties due to irradiation to a total of $2.4 \times 10^{20}$ nvt. Post irradiation heating to $1,000^{\circ} \mathrm{F}$. did not cause any breakdown of the material. Calcium borate is an excellent neutron shield as well as possessing thermal insulating properties. Tests run on graphite to determine its sodium retentivity indicate that, while binders using petroleum bases are not adequate for retention of sodium, an anthracite base is adequate. The use of a borated cast carbon steel in the rotating plug required physical testing, particularly of its machinability. Since the tests indicate brittleness, good machinability and poor weldability, the use of such castings in the plug has been based on low strength requirements and no welding (4-1, 4-31).

Various tests have been run with sodium to determine its qualifications as a heat transfer agent in the Enrico Fermi plant. Sodiumwater reaction, sodium-air burning, sodium cleaning, vapor trap, compatibility of rubber and plastic in sodium, sodium concrete reaction, displacement of sodium in lead-tin-bismuth alloy, compatibility of non-hydrogenous lubricant with sodium, effect of sodium on protective 
clothing, and sodium-insulation reaction are some of the tests which have been conducted (3-12 through 3-18).

\section{Heat Transfer}

The use of sodium to remove heat from fast reactors is based on its excellent thermal and physical properties and on its acceptable neutron absorption characteristics. Its use introduces into power plant operation additional new technology and problems. Considerable experience with the handling of sodium in reactors has been accumulated. This experience indicates that the advantages of sodium far outweigh its problems.

$A N L$.-Sufficient sodium heat transfer data are now available to permit calculation of liquid metal heat transfer coefficients for practical application to sodium-cooled reactors. Experiments with $\mathrm{NaK}$ since 1955 at ANL at temperatures $85^{\circ}$ to $1,175^{\circ} \mathrm{F} ., 4$ to 60 feet per second, Reynolds number 13,000 to 466,000 , Peclet number 268 to 3,850 , average heat flux 28,600 to $3,200,000 \mathrm{Btu} / \mathrm{hr}-\mathrm{ft}^{2}$ (maximum $6,000,000)$ gave Nusselt numbers of 1.4 at low Peclet number, to 22.4 at high Peclet number. Burn-out occurred at the maximum heat flux section when the copper tube reached the melting point of $1,981^{\circ} \mathrm{F}$. (3-58).

Lubarsky \& Kaufman have made an excellent summary of experimental heat transfer data $(3-37)$. The Nusselt-Peclet relationship is normally expressed as $\mathrm{Nu}=a+b \mathrm{Pe}^{c}$. A convenient empirical equation by Monson is

$$
\mathrm{Nu}=2.3+0.23 \mathrm{Pe}^{3 / 3}
$$

Another is $\mathrm{Nu}=0.625 \mathrm{Pe}^{0.4}$, a correlation by Lubarsky and Kaufman. These relationships indicate that for $\mathrm{Na}$ the heat transfer coefficient can run higher than $25,000 \mathrm{Btu} / \mathrm{hr}-\mathrm{ft}^{2}-\mathrm{F}$. at velocities of 25 feet per second, temperatures of $500^{\circ} \mathrm{F}$., and hydraulic diameter of $0.15 \mathrm{inch}-$ typical of sodium-cooled reactor cores.

Enrico F ermi plant.-The APDA steam generator test in support of the Enrico Fermi plant is described in the section Components and System.

\section{Fluid Flow Experiments}

$A N L$.- Reactor transient coolant flow rates were determined by the use of the equations similar to those derived by Acker \& Louis and verified experimentally at ANL and elsewhere.

Extensive test programs have been conducted on the hydraulic pressure drop relations of the core subassemblies including the hydraulic holddown effect.

Qualitative hydraulic tests on a fuel subassembly indicate that the spiral fuel pin construction does provide some fluid mixing.

Enrico Fermi plant.-Pressure drop tests on fuel subassemblies indicate that 18 percent of the 90 psi drop through a fuel subassembly occurs in the entrance, nozzle, and exit; 67 percent in the core; and 15 percent in the upper and lower axial blanket.

Hydraulic endurance tests of the core pin bundle assembly reproducing reactor flow conditions indicate that vibration produces failures of the wire spacing system. This required redesign of the wire assembly. Present design has experienced no failures with flow rates 30 percent higher than nominal.

A 0.25 -scale model of the 15,000 gallon upper plenum of the reactor vessel was tested with water to determine mixing effects during scram. The tests indicated that mixing is effective in this pool to the extent that a core exit transient of over $300^{\circ} \mathrm{F}$. per second is reduced to $300^{\circ} \mathrm{F}$. per 20 seconds or 15 degrees per second. The holddown is an effective mixing agent. The pressure through the holddown was simultaneously tested. This pressure drop is less than 4 psi.

The centrifugal sump-type primary coolant pump was successfully tested in water prior to final shipment. Decay flow characteristics necessary for emergency cooling analyses, as well as developed head, efficiency, and shaft seal effectiveness were determined.

Primary system check valve flow characteristics under back pressure were tested in water, indicating less than $100 \mathrm{gpm}$ flow under system pressure. 
Prototype safety control rod drop tests in sodium show that safety rods can be designed for scram characteristics of 100 inches per second.

\section{Coolant Chemistry}

Large sodium systems are being operated successfully. The sodium coolant system has given excellent trouble-free service. One such system was operated for 2 years without loss of any sodium and with no evidence of corrosion or mass transport. The fuel elements performed perfectly. Early troubles experienced with this system did not result from the sodium coolant and were eliminated by bypassing the superheater section of the boiler. Valuable experience concerning sodium in reastors is being accumulated on the Sodium Reactor Experiment by Atomics International. The operating experience with the Enrico Fermi, Dounreay, and the EBR-II sodium systems and the EBR-I NaK system will provide further information which will be available in time to incorporate into the detailed design of the plutonium-fueled fast breeder reactor (PFFBR).

Based on the results of detailed studies of various gases, argon was selected for the inert gas system of both the EBR-II and Fermi plant. The reason nitrogen, which is inexpensive, was not used in either case was based on a lack of sufficient information regarding the nitriding of exposed component surfaces. The supply system for inert gas supply is maintained by either a gas trailer tank or one of two banks of gas cylinders. All supply sources have pressure-indicator alarms to alert the operator to the gas supply conditions.

Corrosion has already been discussed in the subsection "Other materials," while a discussion of impurities appears in appendix $\mathrm{A}$.

$A N L$.- The Liquid Metals Handbook and its supplement and other previous data regarding sodium chemistry have been supplemented by extensive experimentation on such items as sampling and analysis for impurities in sodium systems.
A vacuum distillation process has been improved. The vacuum distillation removes sodium from its nonvolatile impurities and the residue is analyzed by standard radiological or chemical methods.

A plugging indicator, developed by KAPL is also used for direct oxide determination for checking efficiency of cold trapping. "Cold trapping" technique for oxide removal, well developed at $\mathrm{KAPL}$ for the Submarine Intermediate Reactor (SIG) and the S2G Sodium Reactor (S2G) programs, has been but little improved.

Enrico Fermi plant.-In the Na-air reaction test $(2-7,2-9,2-10,2-11)$, a stoichiometric amount of hot sodium $\left(850^{\circ} \mathrm{F}\right.$.) injected as a fine dispersion and at a high rate into a 532-liter pressure vessel developed a maximum pressure of 38 psig in 6 seconds. Further tests simulated large amounts of sodium spread out in a pool exposed to air until all the oxygen is consumed. The initial burning rate of sodium was less than $5 \mathrm{lb} / \mathrm{hr}$-sq $\mathrm{ft}$ of burning surface. The tests indicate that the rate is primarily controlled by a diffusion process rather than the velocity of chemical reaction and is proportional to the product of oxygen concentration and the square root of the absolute temperature. These series of tests have shown that containment buildings can be designed in the future with more assurance than at present.

A two-phase NaK-water reaction test program was carried out:

\section{Phase I (3-1)}

Injection of a one-half-inch stream of 600 1,200 -psig and $200^{\circ}-400^{\circ} \mathrm{F}$. water into 50 psig and $600^{\circ}$ to $800^{\circ} \mathrm{F}$. NaK, simulating failure of a steam generator tube developed excessive pressures with zero gas volumes. This pressure was considerably reduced by adding gas volume to 92 percent of the $\mathrm{NaK}$ volume.

\section{Phase II}

Water at 900 psi was introduced through a simulated tube rupture of a $13 / 16$-inch-diameter 
tube into approximately 250 pounds of sodium heated to $500^{\circ} \mathrm{F}$. A relatively large, $26 \mathrm{cu} \mathrm{ft}$, gas surge volume was placed adjacent to the sodium and contained a 30-inch-diameter stainless steel rupture disc to relieve the products of the reactions. Maximum pressures reached were $175 \mathrm{psi}$ in the reaction area, $70 \mathrm{psi}$ at the rupture disc with a maximum temperature of $1,950^{\circ} \mathrm{F}$.

These series of tests have been the basis for the relief system provided in the Fermi plant steam generators, as well as the basis for the design pressure in the secondary system.

\section{Reactor Safety}

Questions have been raised concerning the in herent safety characteristics of the fast reactor because of the behavior and meltdown of the EBR-I during special reactor physics tests. For this reason, the many features of fast power reactors related to safety and control have been extensively studied both in the United States and in England. In the United States, the bulk of this work has been done by Argonne National Laboratory, Los Alamos Scientific Laboratory, and by APDA and its contractors.

The EBR-I was initially constructed not as a device to prove the kinetic aspects of fast reactor behavior but as an experiment to show the physics practicality of breeding and the engineering practicality of using a liquid metal coolant. The early demonstration of a prompt positive power coefficient in the EBR-I led to speculation that some inherent characteristic of fast reactors was at fault. Although not as yet conclusively proven, recent experiments have yielded circumstantial evidence at least that core distortion was at fault. If this is the cause, then there are no inherent fast reactor characteristics which make it less safe than other power reactors. Consequently, no extra costs are to be expected in providing for the fast reactor the safety features required to control the hazards of radiation.

Extensive work is being carried out on reactor safety associated with characteristics attributed to fast reactors. The problem receiving most attention is supercriticality and consequent energy release association with the agglomeration of a high concentration of fissionable material. The results to date have been encouraging, but analyses have not been extended to plutonium systems nor to the larger reactor of the 10-year program. Safety programs should be reviewed after reference reactor systems are established. In the meantime generalized studies, some of which are discussed, should be carried out. In addition to the studies on cross sections, alpha, beta, and temperature coefficients of reactivity, further work should be done on bowing of fuel subassemblies and on the nature of plutonium system meltdowns with and without sodium.

Past status (1-20).-The past several years have seen major advances made in the field of fast reactor safety. Four years ago, the major items under discussion at an APDA-sponsored meeting on fast reactor safety and controls (1-28) included the following:

(1) A first theoretical effort at the Doppler effect in fast reactors.

(2) A report on a prompt positive reactivity coefficient and some tendencies toward spontaneous oscillation of power in the Mark I or Mark II cores of EBR-I. The meeting produced the suggestion for oscillating experiments as a means for investigating these undesirable dynamic characteristics. It was suspected that the Doppler effect or rod bowing played a major role therein.

(3) Parameter studies on the effects of step and ramp insertions of reactivity. Performed with assumptions only approximating a real reactor, these calculations, nevertheless, provided some insight into the size of insertion which would cause trouble, without defining the manner of reactivity introduction.

(4) Some very qualitative discussions of hypothetical accidents which might lead to a core meltdown or a nuclear burst. Also, some very brief discussions of the manner of fuel element failure upon overheating, including 
some speculation on the possible melting of fuel pins in a Godiva burst.

Present status (1-20).--The present status of the work was reviewed in two papers (1-48, 1-50) and brought up to date at a second APDA-sponsored meeting on fast reactor safety in March 1959. The situation has changed considerably in the 4 intervening years, as follows:

(1) Refined measurements of the Doppler effect have been made both in the United States and England, showing it is too small to have played a major role in EBR-I. The experiments are in semiquantitative agreement with recent theoretical predictions, but more careful work may be in order.

(2) The Mark II core of the EBR-I was oscillated, showing a large resonance for certain ratios of power-to-flow. This core was partially melted during the series of kinetics investigations, and has been replaced by a new "rigid" Mark III core, wherein fuel element bowing was prevented. The Mark III core is highly stable and shows no sign of a positive reactivity coefficient. Considerable theoretical progress in the understanding of the dynamics of fast reactors has been achieved. However, only partial success has rewarded the attempts to calculate quantitatively from first principles the detailed behavior of the Mark II or Mark III cores.

(3) Accident studies have shifted from ramp insertions of reactivity to meltdown studies and explosion calculations. Reactors under design have been instrumented and designed to make the likelihood of "startup" accidents and loading mishaps remote. Similar precautions have been taken against the loss of coolant accident, etc., so that it becomes difficult to define a "credible" accident which will lead to core meltdown and the possible subsequent reassembly in a more reactive form.

(4) Only partial success has rewarded the theoretical efforts thus far on the difficult problems of prescribing the course of a meltdown. Some out-of-pile experiments have been performed and more are in preparation.
A new Transient Reactor Test Facility, TREAT, a source of neutron bursts for engineering tests, has been designed and constructed especially to permit controlled studies of the modes of failure of fast reactor fuel elements upon overheating. The mechanisms important to dispersal or reassembly will be studied herein to provide a guide for further theoretical studies.

(5) New methods of computing the energies and pressures developed in hypothetical nuclear accidents have been devised. Uncertainties still remain in the specification of the equation of state for temperatures from $10^{4}$ to $10^{5}$ degrees Kelvin, in complications of geometry, and especially in the determination of the threshold energy for pressure buildup, as influenced by voids initially present in the exploding medium.

(6) Experience with ZPR-III provides reasonable confidence in the prediction of most static physics properties of fast reactors. On the other hand phenomena such as fuel element swelling due to fission products gases, density changes due to phase changes and the effects of boiling sodium on a meltdown have risen into some prominence. Furthermore, bowing of fuel elements and subassemblies thereof remains a very real and practical problem, and the reactor designer must exercise considerable care to control its effects in each new design.

EBR-I kinetic studies (1-21).--One of the main features incorporated into the design of the Mark III loading of EBR-I is a tightening rod for varying the clearance between neighboring fuel and blanket rods.

With the tightening rod in the expanded condition, the fuel rods are forced outward against the inside of the hex can. With the tightening rod in the closed condition a total clearance of 0.070 inch between rods is allowed.

This design makes possible a direct investigation of possible rod bowing effects which have long been suggested as the source of the positive temperature coefficient of reactivity observed in the Mark II loading. 
The results of transfer function measurements and flow change tests carried out with all fuel tightening rods loose failed to reveal any significant evidence of a positive temperature coefficient of reactivity. Within the limits of experimental accuracy no change was noted in the phase and amplitude of the transfer function. Sudden decreases in coolant flow rate were accompanied by an immediate reduction in power. Conversely, flow increases caused an immediate increase in power. Such behavior contrasts sharply with the results of similar tests conducted on the Mark II reactor. In this case a flow descrease resulted in a sudden increase in power, the result of a prompt positive temperature coefficient, followed by a slower decrease to some lower equilibrium power level.

The Mark III results should not be interpreted as a rejection of rod bowing as a possible mechanism for temperature dependent reactivity effects. The fuel rods were not rigidly fixed above and below the fuel section. Further tests will be conducted to establish the existence or absence of rod bowing effects. Transfer function and power coefficient measurements augmented by flow change tests will be conducted. The results will be compared with the rigid reference core. Any difference caused in the reactivity feedback will then be subject to interpretation in terms of material displacement.

TREAT (1-22, -23).- The TREAT reactor is a graphite-moderated system with the fuel uniformly distributed as uranium oxide particles in the micron-size range. It has been built as a versatile transient testing facility with primary emphasis on meltdown studies of fast reactor fuel elements. The reactor building was completed in October 1958 and the reactor went critical in February 1959. It is now undergoing shakedown and physics experiments prior to actual test runs.

Provisions for experimental facilities are of two primary types: (1) vertical holes for capsule iests with attendant external holes to provide for loop installations, and (2) horizontal access holes through shield reflector and core to allow visual and phoiographic observation of experiments in progress. There is also a thermal column.

The primary value of TREAT will lie in the study of fuel element failure and meltdown product motion. The early experimental meltdown work with TREAT will be concentrated on experiments with single fast reactor fuel elements, designed to explore element failure and disassociation mechanisms. These experiments will form the basis for investigations into meltdowns of clusters of pins and the subsequent "melt movement."

A program of initial TREAT meltdown experiments-for convenience divided into series SI and SII-has been planned.

SI and SII will bridge the gap between tests designed to check the characteristics of TREAT as a neutron source and tests on fast reactor fuel elements utilizing TREAT as a source of neutrons for nuclear heating. These series should serve as "proof tests" on TREAT operations and yield information concerning the experimenters" ability to predict occurrences during TREAT bursts and provide actual meltdown data for EBR-II Mark I type of fuel elements.

Both series are experiments on single, uncooled, unirradiated EBR-II Mark I type of pins. SI will use opaque graphite-lined capsules; SII, transparent capsules with fused silica windows, Variables whose effect on sample meltdown characteristics will be studied are total energy input, rate of energy input, and possible perturbations caused by instruments. Data which are desired from the experiments includes pin elongation, fuel-clad eutectic formation, pin hot spots, and types and extent of clad failure.

SI consists of four experiments in which the sample energy input will be sufficient to raise the average pin temperature as follows: SI-1, $\sim 500^{\circ}$ C.; SI-2, $\sim 900^{\circ} \mathrm{C}$; SI-3, $\sim 1,130^{\circ} \mathrm{C}$. (but not melt the fuel), and SI $-4, \sim 1,130^{\circ} \mathrm{C}$. (including enough energy to melt the fuel).

SII consists of six experiments during which extensive pin failure and eutectic formation are expected; burst durations and total energy 
inputs of SII-1 through SII-6 are to be partially dependent on the results of those experiments already completed. Optical motion picture photography, both high speed and normal, will be used with SII. Later tests will include (1) pin immersion in stagnant sodium, and (2) previous irradiation of sample pins.

Experiments with clusters of pins and with pins immersed in flowing sodium are being planned, but for much farther in the future.

Instruments are being developed now for tests on pins in a liquid metal environment. These include special thermocouples, pressure measuring devices and a $\gamma$-ray camera.

Containment (2-19).-The two potential sources of energy that are germane to discussions of containment for fast reactors are (1) possible nuclear energy release following a core meltdown and (2) sodium-air reactions following a sodium leak.

Studies indicate a maximum fission energy release of $5 \times 10^{8}$ calories for any fast reactor system and probably less. Sodium-air reactions are probably lower by a factor of 10 or 100 , and heat stored in the fluid systems is not an important factor for sodium cooled reactors.

These energies do not all become available at the same time in the event of an incident. When released, a large portion is used up in heat capacity of available sinks.

The released energy can develop into pressure and temperature increases, either prompt or delayed.

Containment is necessary with the present state of knowledge. The problem may be eliminated or greatly reduced by :

(1) Increasingly accurate determination of the maximum possible initiating energy release (nuclear and sodium-air reaction), where one can hope to pick up reduction factors of 10 or 100 for the current pessimistic maximums.

(2) Determination of a reasonable division of energy into that soaked up and that which goes to physically damage the system.

(3) Accumulation of damage experience for systems having energy releases of the form encountered, and comparison with currently used assumptions of release as from propellants and high explosives, hopefully only reducing current effects by a factor of 2 or so.

(4) More accurate appraisal of the release of stored energy with respect to the effect on the pressures and temperatures of its time history and removal of energy to existing sinks which may introduce reductions in loading by factors of 10 .

(5) A better determination of pressure loads from materials burning after ejection into the space proximate to the barrier, which may also lead to loading reductions by a factor of 10 .

(6) An attack of the problem of reasonably estimating the motion of radioactive materials to a position of availability for discharge from the system, and determining the time rate of change of this loading as a result of removal through fallout, precipitation, condensation, and radioactive decay to stabler states, all of which could yield reductions in radioactive loading assumptions of 100 or 1,000 initially, and perhaps an additional 10 or 100 subsequently.

\section{Components and Systems}

$A N L$.-Liquid metal pumps: A general program of liquid metal pump development was initiated in 1956 to build and test a 5,000-gpm mechanical centrifugal pump, a 5,000-gpm a-c linear induction pump, and a 10,000-gpm d-c electromagnetic pump. Inspection of the mechanical pump after 6,300 hours of successful operation revealed no measurable wear. Its efficiency is 85 percent overall. The a-c induction pump has operated successfully for over 7,000 hours at $850^{\circ} \mathrm{F}$. Its overall efficiency is 43 percent. Flow control of increments as small as $1 \mathrm{gpm}$ have been demonstrated.

The d-c pump has had difficulty in meeting design head. The pump and its supply of 300,000 amperes require a large physical plant. The mechanical and a-c pumps were chosen for EBR-II. 
Instrumentation : Magnesium oxide insulated thermooouples in stainless steel sheaths have demonstrated in-pile reliability in EBR-I core. The operation of EM flowmeters while submerged in sodium has been demonstrated in the EBR-II model. Commercially available pressure transmitters submerged in the model tank have proved reliable. A self-seeking sodium level probe has been developed for use in remote locations. The use of 60-cycle induction heating of the EBR-II model tank, and of the large 12-inch sodium pump loops has been demonstrated using a thin carbon steel sheath around the stainless steel pipe.

EBR-II model (3-6): The EBR-II 5,000gallon model operated at $700^{\circ} \mathrm{F}$. duplicated the salient features of EBR-II, has been operated since 1955, has demonstrated fuel handling components as well as instrumentation, cold traps, plugging indicators, pumps, heating, and the handling of sodium.

$K A P L S 1 G$ and $S 2 G$.-Extensive research and development at KAPL has undertaken the design of mechanical pumps, electromagnetic pumps, valves, instrumentation, cold traps, plugging indicators, analytical devices, steam generators for use in sodium systems in the S1G and S2G plants. Much of this experience has been useful in designs of fast breeder sodium systems.

Enrico Fermi Atomic Power Plant.-Reactor: Extensive experimental stress studies of the effects of piping reactions on the 30 -inch reactor outlet nozzles were made on a one-quarterscale model. The resultant stresses are lower than estimates made in Bijlaard's analysis.

Experimental verification of the bowing of fuel subassemblies was made, with and without mechanical restraints, at the core center. Core restraint can be designed to give zero net inward movement due to bowing.

Bases for stress analyses have been determined for all possible loadings including effects of thermal shock. Plastic deformation theory is used in setting up stress allowables based on a modified Goodman diagram and $\mathrm{S}-\mathrm{N}$ fatigue curves.
Pumps: Extensive development tests were conducted on pump, shaft seals for the mechanical sodium pumps. These are in an inert gas phase above sodium and use a fluorocarbon oil containing no hydrogen. Tests have been successful and the results incorporated into the pump design.

Once-through steam generators: The practicability of once-through steam generators has been proven by a series of tests on two prototype units.

Starting on September 17, 1956, and continuing for 15 months, a 7-tube horizontal $U$-shell unit once-through steam generator was tested for steady state, transient, and water fouling conditions under various operating conditions. This model contained full-length tubes with as much geometric similarity to a typical full scale unit as possible. NaK 56 alloy was used as the coolant. The unit was made of type 304 stainless steel. Inlet feedwater temperatures were varied between $175^{\circ}$ and $200^{\circ} \mathrm{F}$. Over 16 steady state tests were completed to determine the operating performance. temperature gradients, temperature profiles, and heat balance. Twenty-one transient tests were run to determine temperature response, rate of change, total change, and control response. The unit withstood over 40 normal shutdowns and over 25 forced shutdowns. The liquid metal system and the once-through steam generator were not responsible for any of the unscheduled outages. The NaK temperatures into the steam generator were $950^{\circ} \mathrm{F}$. maximum, and $450^{\circ} \mathrm{F}$. at the outlet. Steam temperatures ran from over $900^{\circ} \mathrm{F}$. down to $680^{\circ} \mathrm{F}$. depending upon the load. Transient changes from 50 to 75 percent load were made in 30 seconds.

Once-through steam generator operation has been completely satisfactory in all respects. The tests indicate that a single wall tube design of a once-through unit is quite practical. There is no evidence to date of either water side or liquid metal side deposits extensive enough to cause measurable losses, heat transfer or increases in pressure drop. 
A second 7-tube bayonet type vertical oncethrough steam generator was installed after the completion of the first test and operated for a total of 472 hours. The steam generator tubes in this unit were made of $21 / 4$ percent $\mathrm{Cr}, 1$ percent Mo ferritic steel. The operating experience and results of tests indicate that this type unit could be readily adaptable for plant service and again proves that a once-through steam generator for sodium use is quite practical.

Vapor traps: The test of a sodium vapor trap using various meshes is still proceeding.

Reactor components test: All major components in the primary system for Fermi will be mechanically and hydraulically tested in hot gas and sodium in a test facility comprising the reactor vessel, rotating plug and drive, fuel handling mechanisms, holddown, two safety rod drives, two operating rod drives, oscillator drive, one piping loop with pump, and dummy fuel and blanket subassemblies. The tests are scheduled to begin July 1959, and will continue until summer 1960 prior to completion of the plant.

\section{Fuel and Materials Properties}

Uranium oxide-stainless steel dispersion fuel elements.-Stainless steel clad fuel elements containing a core of $\mathrm{UO}_{2}$ dispersed in a stainless steel matrix have been extensively studied, the largest scale application being a core loading of plate-type elements for the Army Package Power Reactor (SM-1). For high power density, enriched uranium-fueled reactors, the stainless steel dispersion or cermet combines the advantages of excellent high temperature stability and ability to accommodate fission products of a stable ceramic, with the high strength, relatively high thermal conductivity of stainless steel. Irradiation tests have shown that through proper choice of $\mathrm{UO}_{2}$ particle size, most of the fission products can be retained in the $\mathrm{UO}_{2}$, minimizing damage to the steel matrix and avoiding the extensive embrittlement that occurs in alloy systems.

Fabrication studies have been carried to the point that some types of elements are essentially commercially available items. Based on powder metallurgy techniques for forming $\mathrm{UO}_{2}$-stainless steel compacts, flat plates have been fabricated by the "picture frame" hot rolling process, externally and internally clad tubes by powder rolling, and cylinders have been fabricated by hot swaging, hot extrusion, and a "cold binder" process.

Irradiation and metallographic data indicate that the performance capability of a $\mathrm{UO}_{2}$ stainless steel dispersion fuel element is a definite function of the shape, core thickness, and temperature, and that the thermal stress level may also be important. The performance limits have not been completely defined for this type element, particularly the effect of lowering the temperature of the cylindrical elements. The SM-1 type of elements has been successfully irradiated to 50 percent burnup of the uranium in the dispersed phase at temperatures below $800^{\circ} \mathrm{F}$. 


\section{REACTORS COMPLETED OR UNDERWAY}

\section{Experimental Breeder Reactor No. 1}

Mark-I and Mark-II cores.-Refer to figures 4 and 5, appendix D. The reactor consists of three principal parts (Fig. 4). The core of the reactor is an assemblage of small diameter cylindrical fuel elements. These contain $U^{235}$ enriched to about 90 percent. Surrounding the core there is an inner blanket composed of larger diameter rods, each containing natural uranium. The core and the inner blanket are cooled by a sodium-potassium alloy. The coolant is contained by a doublewalled tank which fits closely around the inner blanket. The third part of the reactor consists of an outer blanket constructed from natural uranium and having a high uranium density. The outer blanket is air-cooled and is movable. It also contains the control rods. By restricting all movable parts of the reactor to the aircooled outer blanket, it was possible to avoid bearings and other moving machinery inside the tank containing liquid metal. At the time the reactor was designed, the techniques of operating moving parts in a liquid metal system were not as well developed as they are now, and the expedient of putting all moving parts in an air-cooled blanket was recognized as being suitable only for this experimental application. Ultimately, it turned out that the air-cooling of the blanket was the limitation on the operating power level of the reactor.

In the Mark-I loading the fuel bearing section of each element had two spacer ribs 0.042 inch high located so that when the triangular positioning tips of the elements were engaged in the matching holes in the tube plate, the ribs were brought in line with neighboring rods.

In the Mark-II loading the spacer ribs were omitted and the positioning tip was made cylin- drical, thus permitting 0.046 -inch separation of rods.

In the Mark-I core four slugs 0.364 inch in diameter and 17/8 inches in length were loaded in most rods. Some were loaded with slugs 0.384 inch in diameter by 2.5 inches long. Below the fuel, a 4.5-inch-long natural uranium slug was loaded as part of the lower blanket, and above the fuel an 8-inch natural uranium slug was loaded as the top blanket. In the Mark-Il loading the fuel slugs were U-2 percent $\mathrm{Zr}$ alloy, $41 / 4$ inches long by 0.384 inch in diameter, with a lower blanket slug $41 / 4$ inches long and an upper blanket slug 8 inches long. The annulus between slug and fuel tube was filled with NaK as a heat transfer bond.

EBR-I was designed in 1948-50 with two fundamental objectives in mind. The first was a demonstration of the ability of a fast neutron reactor to breed, and the second was a demonstration of the feasibility of the use of liquidmetal cooling systems in power producing reactors.

EBR-I was based on concepts proposed by Enrico Fermi and W. H. Zinn in 1945. The research and development program was approved in 1945, and the AEC approved construction in November 1947. Design ran from 1948 to 1951. Criticality was reached in August 1951, with electricity generated on December 22, 1951. Mark-II core was installed in 1954. A series of kinetic experiments in November 1955, led to a core meltdown on November 29, 1955.

The EBR-I was operated over 4 years, or longer than any other AEC power reactor has operated with the exception of the Submarine Thermal Reactor. During this period it gave essentially trouble-free operation. The NaK cooling system performed successfully. Under 
normal operating conditions the reactor was very stable and did not exhibit either a net positive temperature coefficient or a resonance. Under purposely imposed and drastically abnormal operating conditions anomalies were observed: resonance consisting of oscillations in power level appeared during experiments in which the coolant flow rate was drastically reduced; a net positive temperature coefficient appeared during startups undertaken with reduced coolant flow. Even under conditions where the net positive coefficient appeared, the reactor could be operated safely. Oscillator tests were conducted on the reactor and succcess-

- fully demonstrated the presence of instability.

The operation of EBR-I demonstrated among other things that (1) breeding was a technically achievable objective and (2) that the use of liquid-metal coolant (sodium potassium alloy in this case) was compatible with breeding economy as well as metallurgically and mechanically feasible. EBR-I's operation together with that of Clementine provided experimental corroboration of previous theoretical determinations that neutron behavior below prompt critical is the same in fast and thermal reactors.

In November 1955, the Mark II core of the EBR-I partially melted down during the last of a series of experiments designed to study its behavior when put on positive periods with reduced or zero coolant flow, conditions which are set up only for experimental purposes. The accident occurred under extremely abnormal operating conditions purposely imposed on the reactor for the experiment and recognized to involve a risk of causing melting. Two of the normally operative safety mechanismsthe flow interlock (which automatically shuts down the reactor if substantially full coolant flow is not maintained) and the period scram meter interlock (which automatically shuts down the reactor if the period becomes too short)-were purposely disconnected. The coolant flow was stopped completely. A cer- tain fixed amount of reactivity was put into the reactor with the control rods, and the reactor was started up on a short enough period so that temperature differentials would be established in the fuel slugs. The net positive temperature coefficient previously observed appeared and, as the power increased, the reactivity increased, thus further increasing the power. It was planned to scram the reactor when the period reached 1 second or the power reached 1,500 kilowatts. When the period reached 1 secord, the operator mistakenly activated the slow acting control rods instead of the faster acting scram mechanism. By the time the scram was used, the period had reached 0.3 second. The temperature overshot so that the uranium became heated above $1,328^{\circ} \mathrm{F}$., roughly the temperature at which the uraniumiron eutectic forms. The center of the core melted, forming the eutectic. After the manually operated scram button was pressed, the reactor shut down and the meltdown stopped. The automatic power limitation circuits also operated.

As a result of the accident, the EBR-I core partially melted. No explosive force developed. None of the remainder of the reactor, including the inner blanket and the reactor vessel, was damaged. A negligible amount of radioactive material reached the atmosphere through the stack and through temporary thermocouple connections. Neither the operating personnel nor any other persons were injured in any way and, after evacuation to enable precise measurements, the operating personnel returned immediately to the reactor building.

Figures 4 and 6 show the significant cross sections and flow diagrams.

Some of the design parameters are tabulated below :

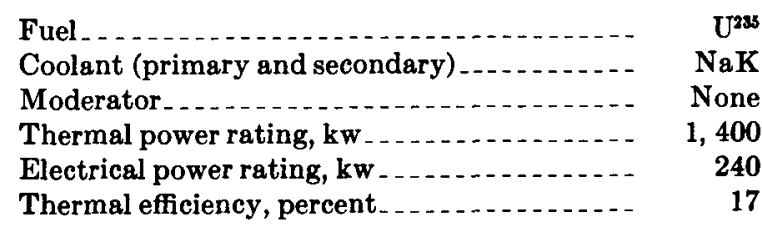


Temperatures, ${ }^{\circ} \mathrm{F}$. :

Reactor inlet.

Reactor outlet.

Superheater NaK inlet

583

Superheater NaK outlet. . . . . . . . . . . .

Steam generator $\mathrm{NaK}$ inlet............

Steam generator NaK outlet. ..........

Feedwater temperature.............

Water heater outlet temperature.......

Steam generator steam outlet temperature.

Superheater steam outlet temperature _. -

Steam pressure, psia . . . . . . . . . . . . . . . .

Core size:

Equivalent diameter, inches (approximate) . . . . . . . . . . . . . . . . .

Length, inches

Volume, cu ft

Core power density average, kw

Fuel enrichment, percent (approximate) .....

Conversion ratio:

Core.

Inner blanket

Outer blanket

Control rods.

035

Total

1. 009

Core loading U-235, kg - -

Specific power, $\mathrm{kwt} / \mathrm{kg}$ fuel

uel temperature, ${ }^{\circ}$ F.-center of fuel rod adjacent to center rod

Average heat flux, Btu/ft' $-\mathrm{hr}$ 209,000 $\Delta \mathrm{T}$ across core, ${ }^{\circ} \mathrm{F}$

Mark-III core.- Refer to figures 6, 7, and 8 , appendix D. After the November 1955 , incident, a Mark-III core loading was designed in order to continue the important investigation of fast reactor stability.

The fuel rod shown in figure 6 consists of a highly enriched uranium 2 percent $\mathrm{Zr}$ alloy slug coextruded with a 0.020 -inch zirconium jacket. Similarly extruded natural uranium 2 percent $\mathrm{Zr}$ sections are welded on above and below the fuel to provide the upper and lower blanket. This construction prevents bowing of fuel slugs inside the jacket. Inner blanket rods are made similarly of one coextruded natural uranium 2 percent $\mathrm{Zr}$ section. Three ribs of 0.046 -inch zirconium wire are welded on with $120^{\circ}$ spacing. The rods are fitted with triangular tips to so orient them that each rib contacts the adjacent fuel element.

The central rod is a nonfuel bearing rod capable of being expanded after insertion into the assembly. When expanded, the tightening rod forces the fuel elements against each other and against the hexagonal subassembly can, thus preventing bowing of fuel elements inside the assembly.

Figure 7 shows a plan view of the reactor core and inner blanket at the reactor centerline. Notice particularly, the clamping arrangement to insure tightness of the subassemblies. Figure 8 is a cutaway view of the inner tank assembly. Notice the fuel subassemblies are positioned at the lower tube plate, clamped at the reactor midplane as mentioned above, and clamped just above the coolant inlet at the seal plate, thus eliminating the possibility of subassembly bowing.

Coolant flow is directed in series or parallel by means of the inlet and throttle valves. The reactor has been thoroughly instrumented with thermocouples in fuel and blanket elements, coolant passages, and structural members.

The reactor system outside the double walled reactor tank is unchanged, i.e., just the inner core structure has been modified.

Tests have been conducted on Mark-III at powers up to $1,200 \mathrm{kw}$ and flows as low as 110 gpm.

Flow changes at power reveal no indication of a prompt positive reactivity coefficient.

Measurements of the transfer function have been made by the null-balance method. It is believed that the accuracy of this system is \pm 1 percent on amplitude and $\pm 1 / 2^{\circ}$ on phase, thus permitting fairly accurate separation of the feedback.

Experience with EBR-I has shown that:

(1) Instability of reactors is not a function of the neutron energy spectrum.

(2) Instability is created by delayed negative power coefficients.

(3) Prompt positive coefficients tend to lower the power at which instabilities will be noticed. 


\section{Clementine}

The Los Alamos fast plutonium reactor was a low power experiment built to demonstrate the feasibility of reactor operation with plutonium fuel and fast neutrons and to serve as an experimental neutron facility. The fuel was fully-enriched plutonium contained in steel cans and cooled by circulating mercury. Construction of the reactor was approved in December 1945, and the reactor operated until June 1953 , at which time it was dismantled as a result of a ruptured fuel element.

The construction of Clementine was initiated to explore the uses of plutonium as a fuel for small reactors and for future power reactor studies. Construction of the reactor provided the Laboratory with a high-intensity source of fast neutrons for nuclear research as well as a device for studying methods and ease of control of a fast reactor.

Actual construction of the reactor was started in September 1946. The first critical assembly of the reactor was made at an incomplete stage of construction on November 21, 1946 , and nuclear measurements were performed at approximately 1 watt of power level without further construction until February 1947. During this period the reactor was used as a critical assembly and measurements were made concerning the critical mass vs core configuration, effectiveness of reactor control, temperature coefficient of the reactor, and spectrum of the neutrons. Work of this nature generally continued until January 1949 , when the reactor was prepared for final assembly. In March 1949, the reactor was brought to full power.

Of the $31 / 2$ years spent in assembly of the reactor, approximately 21 months were spent doing low-power critical experiments. In December 1952 , it became evident that a plutonium fuel rod had ruptured thereby releasing plutonium into the mercury coolant. Inasmuch as the primary objectives of the experiment had been realized, it was decided to dismantle the reactor. The disassembly was completed by June 1953. Details are given in LA-1575.

Significant design parameters are shown below :

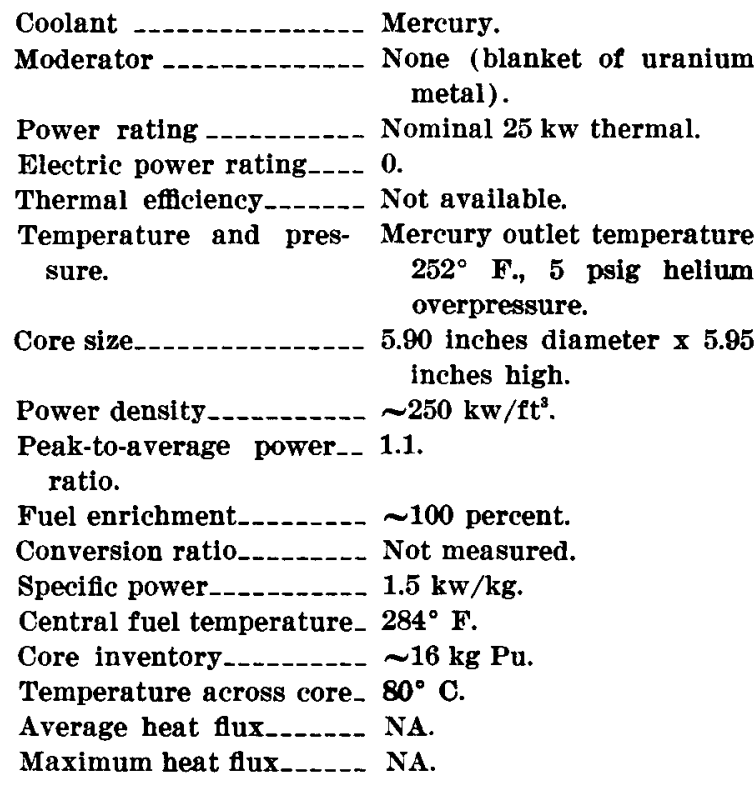

\section{Experimental Breeder Reactor No. 2}

Refer to figures 9 through 15, appendix D. The Experimental Breeder Reactor II (EBR-II) is under development as one part of the U.S. Atomic Energy Commission's experimental power reactor program. The EBR-II is an integral nuclear power plant; it includes a complete fuel processing and fabrication facility in addition to the reactor, heat transfer system, and steam-electric plant. The thermal power rating of the reactor is $62,500 \mathrm{kw}$. Gross electrical power output rating is $20,000 \mathrm{kw}$. Engineering design and component development are presently nearing completion. Construction of the plant is in progress at the National Reactor Testing Station; operation will begin in 1960 .

Exclusive of fuel recycle aspects, the design objectives of the EBR-II are: to attain high thermal performance (high core power density and high coolant temperature level); to achieve efficient breeding (large breeding ratio); to 
utilize insofar as possible prototype components (components of such size, design and cost as to permit their use in central station plants with little or no modification); and, to provide a highly flexible, experimental reactor facility for investigation of reactor configuration parameters, advanced fuel element designs, and improved fuel alloys.

The design objectives of the fuel recycle facility are: to determine the technical feasibility of pyrometallurgical processing and remote fabrication of spent fuel elements; and, to provide a versatile, experimental facility for investigation of new or improved processing techniques and remote refabrication methods.

The power cycle is comprised of three major systems: (1) the primary system, consisting of the reactor and the primary sodium cooling system; (2) the secondary system, or the intermediate sodium heat transfer system; and (3) the steam-electric system.

The complete primary system is contained in a single vessel, or "primary tank," 26 feet in diameter and 26 feet in depth. All of the primary system components, including the reactor, sodium pumps, primary piping, heat exchanger, and fuel transfer and storage system, are submerged in the large bulk volume $(80,000$ gallons) of sodium within this tank. This arrangement provides a number of advantages. Among these are: loss of coolant becomes virtually impossible; rapid changes in load demand or secondary system conditions are prevented from being reflected as temperature changes in the coolant entering the reactor; practically all radioactivity associated with the power cycle is confined to this one location, thus minimizing greatly the probability of a radioactive leak or spill; and, high integrity of the primary sodium piping is not required, since all leakage is into the bulk sodium. The two main pumps provided operate in parallel and supply $8,600 \mathrm{gpm}$ primary sodium flow. Both pumps are of the motor-driven, centrifugal type, the heat exchanger, and back to the bulk sodium, in that order. The temperature of the sodium at inlet to the reactor is $700^{\circ} \mathrm{F}$., and at outlet from the reactor $890^{\circ} \mathrm{F}$.

The reactor is of the heterogeneous type, unmoderated and sodium-cooled. Control is effected by movement of fuel into and out of the reactor core. A total of 12 peripherally located control rods are employed, of which one is used for regulation. The core is of the shape of an approximate right circular cylinder, with $\mathrm{L} / \mathrm{D}$ of about 0.8 . Maximum core power density is about $1,300 \mathrm{kw} /$ liter of core volume, or about $4,000 \mathrm{kw} /$ liter of fuel alloy volume. Breeding blankets of depleted uranium surround the core on top, bottom, and sides. The major fraction of breeding takes place in these blankets; the remainder occurs in the core. For initial reactor loadings, the fissionable material to be employed is $\mathrm{U}^{235}$, and for subsequent loadings, $\mathrm{Pu}^{238}$. The approximate conversion (breeding) ratios expected with these loadings are 1.2 and 1.6 , respectively.

The secondary system transfers the heat from the heat exchanger in the primary tank to the steam generator. This system is nonradioactive and serves to isolate the steam generator from the radioactive sodium of the primary system. A single a-c electromagnetic pump provides a sodium flow rate of $6,300 \mathrm{gpm}$. Sodium temperature at inlet to the heat exchanger is $610^{\circ} \mathrm{F}$, and at outlet from the exchanger, $870^{\circ} \mathrm{F}$.

The steam-electric system receives the heat from the secondary system and converts it to electric power. This system is of essentially conventional design, employing a standard, extracting, condensing, single flow type turbine. An automatic, full capacity, steam bypass system for dumping excess steam directly to the condenser is incorporated to prevent major load changes from effecting changes in secondary system conditions. The condenser circulating water is cooled in a forced convection cooling tower. Turbine throttle flow is $192,200 \mathrm{lb} / \mathrm{hr}$; steam rate is $8.04 \mathrm{lb} / \mathrm{kwh}$. Turbine throttle steam temperature and pressure are $840^{\circ} \mathrm{F}$. and 1,250 psig, respectively. 
The main unit of the fuel recycle facility is a 16 -sided hot cell. This shielded shop contains the equipment for the decanning step (mechanically removing the fuel jackets), melt refining of the spent fuel, the fabrication of new fuel pins, and the assembly of new fuel elements. An ancillary shielded cell is employed for remote assembly of completed fuel subassemblies and for the servicing of main cell equipment.

The large cell is an annular structure 72 feet across flats which contains a shielded central control room 20 feet in diameter. The in-cell atmosphere is high purity argon; pyrophoric materials such as plutonium, uranium, magnesium, and sodium can be handled without special precautions and without the problems associated with "oxide skins." The cell is equipped with manipulators, cranes, shielding windows and services of such design and arrangement that modifications to any processing step or to any of the equipment involved in processing can be readily accomplished.

\section{Enrico Fermi Plant}

Refer to figures 16 through 26, appendix D. In the design of this plant, particular attention has been given to safety and to achieving reliable operation.

It is being built in accordance with ASME and other codes, wherever such codes apply. The schedule for construction provides about 1 year for nonradioactive testing of all of the key components of the plant. A 9-month preoperational program is planned for the period immediately following initial criticality. During this program the expected operating characteristics will be checked in a range of tests beginning at very low power and proceeding upwards in power as confirmation of expected behavior is gained.

A perspective view of the reactor is shown in figure 16. The core and blanket consists of an assembly of square core and blanket subassemblies arranged to approximate a right circular cylinder about 80 inches in diameter and 70 inches high overall. The core, containing the enriched fuel alloy, approximates a right circular cylinder 30.5 inches in diameter and 30.5 inches high; it is completely surrounded by the breeder blanket.

The reactor core, shown diagrammatically in figure 16 , is made up of the central portions of 101 subassemblies, 91 of which contain fuel, the remaining 10 being control elements. Fuel is subdivided into a large number of partially enriched uranium alloy pins. The end portions of these 91 subassemblies (the axial blanket), and all the 572 radial blanket subassemblies, consist of uranium alloy that has been depleted in $\mathrm{U}^{235}$ and fabricated into cylindrical rods. Plutonium is produced both in the core and in the blanket.

Insertion of boron-carbide poison rods in the core provides regulating and safety control. Regulating control is by two boron carbide rods located near the center of the reactor. Eight safety (shutdown) boron rods are situated at about the half-radius of the core. Both core and blanket are cooled by sodium that is pumped into the bottom of the reactor vessel, goes upward through these sections into a large sodium pool, and flows out near the top of the pool.

Core and blanket subassemblies are loaded and unloaded by an offset handling mechanism mounted in a rotating shield plug, both shown in figure 16. A holddown plate below the plug holds the core subassemblies against the pressure drop forces caused by coolant flow through the subassemblies. This plate and the holddown drive shaft also guide the control element drives. 'The offset handling mechanism transfers the spent subassemblies to sodium-filled pots in the transfer rotor container, where they decay during the next cycle of operation at power. During the next plant shutdown the spent subassemblies, with their pots, are lifted through the exit pipe into a cask car. The car then carries the spent subassemblies from the reactor building to a decay storage building. In the car, decay heat from the subassemblies and pots is transferred to an inert gas atmosphere which will be circulated through an external heat exchanger that is integral with the 
cask car. New subassemblies are inserted by the reverse procedure.

The heat transport system is shown schematically in figure 18. Heat is removed from the reactor core and blanket by the primary sodium coolant, transferred to the secondary sodium coolant in three parallel intermediate heat exchangers, and finally is transferred to water and steam in three once-through type of steam generators. There are three primary coolant loops and three secondary coolant loops.

In both primary and secondary systems, the sodium coolant flow rate is $13,200,000 \mathrm{lb} / \mathrm{hr}$, resulting in an average coolant temperature rise across the reactor or intermediate heat exchanger of $250^{\circ} \mathrm{F}$. at a thermal power level of $300 \mathrm{Mw}$. The primary sodium enters the reactor at $550^{\circ} \mathrm{F}$. and leaves at $800^{\circ} \mathrm{F}$.

Extensive steps have been taken to assure that sodium will not be lost from the system. These include syphon breaks, secondary containment of the primary sodium system where a single failure would cause loss of coolant, and enclosure of the reactor vessel in a leak-tight primary shield tank so sized and constructed that adequate cooling can be maintained even if the reactor vessel fails.

Failure of the primary system due to thermal shock has been guarded against by extensive use of thermal baffles and bypass flow. The primary shield consists of a 12-inch stainless steel thermal shield inside the reactor vessel and a 30-inch partially borated graphite shield between the reactor vessel and the primary shield tank. The thermal shield, positioned against the inner wall of the reactor vessel, protects the vessel from radiation damage due to fast neutrons and also absorbs gamma rays, thus reducing heat generation within the vessel walls and the borated graphite.

The partially borated graphite shield is designed to moderate and absorb enough neutrons to avoid serious heating within the steel-lined concrete shield wall (2.6 feet thick) that completely surrounds the primary shield tank. This shield wall divides the lower part of the reactor building into an inner reactor compart- ment and an outer equipment compartment. The latter contains all primary coolant system pumps and heat exchangers as well as decay tanks and other equipment. The shield is designed to reduce the neutron flux in the equipment compartment to less than $10^{4} \mathrm{n} / \mathrm{sq} \mathrm{cm}-\mathrm{sec}$ in order to prevent significant activation of the secondary coolant and the equipment in the outer compartment. The steel lining on both faces of the concrete prevents heating within the concrete due to intense $\mathrm{Na}^{24}$ gamma rays from the primary coolant, whose activity level is about 0.05 curie/cc.

Neutrons are kept from streaming along the large sodium pipes and into the equipment compartment by installing the greater part of the pipe length within the reactor compartment (i.e., inside the secondary shield), and by enclosing the pipes in a neutron shield. A concrete biological shield wall 7 feet thick is outside the reactor containment building, and a steel and concrete operating floor shield 5 feet thick is above the reactor and equipment compartment to reduce radiation levels to one-third AEC tolerance.

An airtight steel cylindrical reactor building, shown in figure 19, encloses the reactor, the fuel-handling mechanism, the intermediate heat exchangers, and the sodium pumps, piping, and storage tanks. It is 72 feet in diameter and has a wall thickness of 1.125 inches. The purpose of this building is to contain radioactivity from any reactor accident that might release fission products and radioactive sodium. Air in the reactor and equipment compartments below the operating floor is depleted of oxygen and dehumidified to prevent fires in these compartments in case of a sodium leak.

Flexibility has been designed into the system. All mechanisms, including the rotating plug, the subassembly handling mechanism, and the holddown mechanism, can be removed, as can the control drive, rods, guide tubes, and core subassembly support plates. The core subassemblies and the first row of blanket subassemblies are the same size and, with minor modifications, are interchangeable. Conse- 
quently, core size can be adjusted if necessary during initial startup to achieve criticality. Furthermore, after some years of successful operation at design power, the core size can be increased to augment the power output.

\section{British Fast Reactor Effort}

A following description of the British fast reactor, now going into operation at Dounreay, Scotland, is excerpted from the Second Geneva Conference Paper $(15 / \mathrm{P} / 274)$ by $\mathrm{H}$. Cartwright, J. Tatlock, and R. R. Matthews. This reactor is expected to go critical on August 15, 1959.

The Dounreay fast breeder reactor was first considered as a probable project in 1952, and the early decisions in design were therefore taken 5 and 6 years ago. Although the present layout of the plant is not intended to be a prototype for future systems of this type, it is useful at this stage to note and understand the engineering design philosophy behind some of the principal features of the Dounreay reactor.

The majority of these early decisions of principle tended toward caution and conservatism as the need to achieve complete safety during normal and possible /abnormal operating conditions was, and has remained, the feature dominating all design thinking.

In the general approach to the overall design it was considered that the most important objective was to build and operate at power a fast breeder reactor. It was also recognized that the core design with which the reactor would start might well have to be modified in the light of experience.

As well as being a fast fission system, this reactor is the first in the United Kingdom to use a liquid metal coolant on a large scale. Such a circuit has its own problems, and in the Dounreay reactor it was decided not to provide facilities for circuit component testing, nor to attempt to make an economic heat rejection system the prime objective. The philosophy was that the experimental part of the reactor system should be the part in the reactor vessel, and outside this every effort should be made to reduce to a minimum the risk of breakdown of the cooling system. This has in certain instances meant that some of the design problems that will need to be solved in order to build fast reactors at low capital cost, e.g., economic liquid metal/water heat exchangers, have been avoided in the interests of soundness and reliability on this particular project.

The fuel element consists essentially of a tube of enriched uranium, clad on the outside with nobium and on the inside with vanadium. The length of the fuel section is 21 inches, above which is a 6-inch breeder piece of natural uranium. The top and bottom end pieces are of stainless steel. With the high thermal ratings required for economy in fast reactors, upwards of 100 watts/gram of fuel, a large surface-to-volume ratio is required to give reasonable thermal fluxes, and thin sections are needed if maximum fuel temperatures are not to be excessive.

At an early stage of design it was decided to have coolant flow down through the core.

Three basic methods of giving control were originally considered, i.e., movement of the reflector, movement of the fuel or movement of an absorber. The total amount of control available from movement of the reflector was limited and as no effective absorber such as boron-10 appeared likely to be available in sufficient quantity, it was decided to control by movement of the fuel. It is probable that if the choice were made today, the preference would be for boron-10 absorbers as these require less space, the cooling problem is not so severe, and they would not require discharge as frequently as fuel element control rods. The capital cost of boron-10, however, is quite high.

The control of the Dounreay fast breeder is thus achieved by moving 12 groups of 10 fuel elements each, which are situated around the edge of the core. These groups are split up into two safety rods, six control rods and four shutoff rods. The mechanism for operation of the control gear is one of the more complicated features of the Dounreay reactor and illustrates the difficulties of implementing what appeared 
at first to be a fairly simple design requirement.

Movement of the control rod mechanism is obtained by the use of a vertical ball-nut and screw actuator, driven through an electromagnetic clutch from an electric motor and gearbox outside the reactor vessel. The use of the electromagnetic clutch eliminates the problem of sealing glands.

The properties and price of sodium make it the most suitable coolant for a fast reactor. It does, however, have the disadvantage that it is solid at room temperatures and consideration was given to the use of sodium potassium alloys for cooling the Dounreay fast reactor. It was recognized that the use of sodium potassium would be an advantage in the early stages of commissioning and operation when liquid metal could be circulated under varying temperature conditions without fear of its freezing. It was eventually decided that the reactor should be started up with the sodium potassium alloy as the coolant and a change eventually made to sodium. This change is unlikely to be made until about 18 months after the reactor has been commissioned.

The decision to have a large number of independent cooling circuits has led to a fairly complicated heat rejection system. To maintain independence each pair of primary pumps and their associated secondary pumps are fed from independent electrical supplies. The power supplies for operation of the Dounreay reactor are obtained from 12 diesel-electric sets with suitable standby, each one of which supplies the power for a pair of secondary circuits and the corresponding primary circuits. Care has had to be taken in the design to insure that the principle of independence has been maintained throughout; for example, in providing standby electrical supplies it was important that these should not be coupled-in to the switchboard in such a way as to link two diesel-electric sets. The principle of separation has meant that each pair of primary coolant circuits is connected to a heat transfer unit which is completely independent of all others right through the steamraising plant as far as the sea-water cooling system. The resulting steamplant is elaborate and expensive and should not be taken as an indication of the type of steamplant that would be adopted for future fast reactors. It does, however, illustrate very clearly the way in which detailed design can be markedly affected by an overall principle.

The economics of power from fast breeder reactors are materially affected by the costs of fuel cycling and the capital cost of the plant. Because the fast reactor is a highly rated system, there is a distinct possibility of getting a low capital cost installation. Much, however, will depend on developments in the engineering of reliable large-scale liquid metal circuits, and in the skill of the designer in meeting the problems in and around the reactor core, where the very compactness of the system introduces difficulties of design. A great deal of valuable engineering knowledge has been acquired by designing and building the Dounreay reactor and more will be learned from its operation. Experience has underlined the importance of this project as a stage in the development of economic fast breeder reactors in the United Kingdom.

Significant design parameters are shown below :

\begin{tabular}{|c|c|}
\hline esign heat out & 60 \\
\hline Number of fuel elements._-_.- & 367. \\
\hline Heat transfer surface & 215 sq ft. \\
\hline verage heat flux & $531,000 \mathrm{CHU} / \mathrm{hr}-\mathrm{sq} \mathrm{ft}$. \\
\hline esign heat output (blanket) -- & $12 \mathrm{Mw}$ \\
\hline Number of blanket elements & 1,872 . \\
\hline Heat transfer surface & $4,690 \mathrm{sq} \mathrm{ft}$. \\
\hline Average heat flux & $4,880 \mathrm{CHU} / \mathrm{hr}-\mathrm{sq} \mathrm{ft}$. \\
\hline $\begin{array}{l}\text { Primary coolant inlet tempera- } \\
\text { ture. }\end{array}$ & $200^{\circ} \mathrm{C}$. \\
\hline $\begin{array}{l}\text { Primary coolant outlet tem- } \\
\text { perature. }\end{array}$ & $350^{\circ} \mathrm{C}$. \\
\hline $\begin{array}{l}\text { Secondary coolant inlet tem- } \\
\text { perature. }\end{array}$ & $175^{\circ} \mathrm{C}$. \\
\hline $\begin{array}{l}\text { Secondary coolant outlet tem- } \\
\text { perature. }\end{array}$ & $325^{\circ} \mathrm{C}$. \\
\hline Primary coolant flow rate & $52,000 \mathrm{lb} /$ minute. \\
\hline Secondary coolant flow rate & $52,000 \mathrm{lb} /$ minute. \\
\hline Steam pressure & 200 psia. \\
\hline Steam temperature & $274^{\circ} \mathrm{C}$. \\
\hline eed water temperature & $194^{\circ} \mathrm{C}$ \\
\hline team flow rate & $3,400 \mathrm{lb} /$ minute \\
\hline
\end{tabular}


To support their fast reactor program, the British have considerable facilities. They have extensive fuel fabrication facilities and reprocessing facilities at Dounreay for the fast reactor as well as similar facilities elsewhere. They have critical experiments, such as Zeus and Pluto, at Harwell. There is a sizable effort on metallurgy and fuel development, as well as on physics, being carried on at Harwell and Culcheth. The British are now starting a new study at Risley of a large-scale fast reactor and presently are concentrating on core studies.

\section{U.S.S.R. Fast Reactor Effort}

The U.S.S.R. has built three experimental reactors: $\mathrm{BR}-1, \mathrm{BR}-2$, and $\mathrm{BR}-5$. Their investigations began in 1949 . $B R-1$ was placed in operation in $1955, \mathrm{BR}-2$ in 1956 , and BR-5 in 1957 or 1958 .

BR-1 had a core of $\mathrm{Pu}$ and $\mathrm{U}$ rods, with a uranium reflector, and a maximum power level of 100 watts, with ambient cooling. Its main purpose was to carry out measurements of neutron cross sections at various energies, and to determine breeding ratios.

BR-2 was a $100 \mathrm{kwt}, 10^{14}$ flux, $140^{\circ}$ outlet temperature, mercury cooled reactor fueled with plutonium. Its purpose was (1) to determine neutron cross sections, including elastic and inelastic scattering of materials, (2) capture cross sections of $\mathrm{Pu},(3)$ to obtain operating experience with a liquid metal, (4) to determine stability and reactivity characteristics, and (5) to determine breeding ratios.

$B R-5$ is a transitional reactor between BR-2, the mercury cooled experimental reactor, and $\mathrm{BN}-50$, a power reactor. $\mathrm{BR}-5$ is a $5,000 \mathrm{kwt}$, $10^{15}$ flux, sodium-cooled reactor operating at $932^{\circ} \mathrm{F}$. outlet temperature, fueled with $\mathrm{UO}_{2}$, two loops, one sodium to air, the other sodiumto-water with heat dumped to a condenser. The blanket is part uranium, part nickel. BR-5 has been used to test fuel shielding and components for $\mathrm{BN}-50$, to familiarize personnel with sodium, and to carry out physics experiments at a high neutron flux.

Two power reactors have been designed, $\mathrm{BN}-50$ and $\mathrm{BN}-250$. $\mathrm{BN}-50$ is presumably in a construction phase. It is a $50 \mathrm{Mwe}$, sodiumcooled, $\mathrm{Pu}-\mathrm{U}$ fueled reactor, with $10^{16}$ flux, $900^{\circ}$ F. outlet temperature, and a core 26 inches in diameter, $\mathrm{L} / \mathrm{D}$ equal to 1 . $\mathrm{BN}-250$, presumably in a design stage is a $250 \mathrm{Mwe}$ sodium-cooled $\mathrm{Pu}$ fueled reactor, with $10^{16} \mathrm{flux}, 1000^{>} \mathrm{F}$. outlet temperature, core 42 inches in diameter, $\mathrm{L} / \mathrm{D}$ equal to 1 , with a specific power of 1,000 $\mathrm{kw}$ per liter.

The U.S.S.R. is intensely interested in high breeding ratios using a closed cycle $\mathrm{Pu}-\mathrm{U}$ system, with some interest in a $\mathrm{U}^{233}-\mathrm{Th}$ system.

\section{Other Fast Reactor Effort}

In addition to the British and Russian efforts there are others outside the USA interested in fast reactors. The Belgians have been actively interested for a number of years. Seven reactor scientists have worked at APDA for 3 years. This group represents a well-rounded nucleus for a design team. The French and Germans are also factoring fast reactors in their programs. The French intend to send personnel to APDA in the near future to develop background for the design of fast reactors. The Japanese have completed some preliminary designs of fast reactors, one of them was designed for an internal breeding ratio of one. This was done to provide a system in which the fuel need never be replaced in the lifetime of the reactor. The cores of these reactors are large and the power output is also. The materials problems associated with maintaining the fuel clad integrity was recognized.

\section{Data}

Data for reactors underway are contained in appendix $\mathrm{A}$. 


\section{REACTORS UNDER STUDY}

\section{Plutonium-Fueled Fast Breeder Reactor}

Refer to figures 27 through 31, appendix $\mathrm{D}$. The Plutonium-Fueled Fast Breeder Reactor (PFFBR) under study is an unmoderated, heterogeneous, sodium-cooled fast reactor with a power output of $775 \mathrm{Mw}$ thermal and $300 \mathrm{Mw}$ electrical, fueled with plutonium.

PFFBR is another essential step in the commercial development of economical nuclear power utilizing a full-scale power breeder reactor, designed to operate at substantially less cost than Fermi utilizing Fermi knowledge and experience, and new technology available from research and development programs for Fermi, EBR-I, EBR-II, and Dournreay.

The 300-Mw gross electric output is obtained from heat produced in the reactor which, in turn, produces steam at $870^{\circ} \mathrm{F}$. and $1,450 \mathrm{psig}$ to operate a conventional turbine generator. The net plant heat rate is $9,300 \mathrm{Btu} / \mathrm{kw} \mathrm{hr}$, resulting in a net thermal efficiency of 37 percent, which is comparable to that obtained in a modern conventional steam plant.

The reactor consists of an assembly of hexagonal shaped core and blanket subassemblies arranged to approximate a right circular cylinder about 6 feet in diameter and 8 feet in height. The core, about 5 feet in diameter and 3 feet in height, is completely surrounded by blanket material; therefore, core subassemblies have both an upper and a lower axial blanket section. The lower axial blanket section is composed of depleted uranium 23/4 w/o molybdenum alloy in the form of plates, and the upper axial blanket is composed of depleted uranium dioxide. The fuel section, located between the upper and lower axial blankets, contains about 400 thin stainless steel pins having a section of mixed oxide fuel at about 89 percent theoretical density. The uppermost 22 inches of the pins are void to provide space for fission gases released from the fuel. The radial blanket subassemblies contain a number of $\mathrm{U}$ $23 / 4$ w/o Mo alloy rods bonded by sodium in stainless steel tubes. Altogether there are 188 core subassemblies, 4 control rods, 6 safety rods, 248 radial blanket subassemblies and 46 void spaces in which spent fuel subassemblies can be stored for decay heat removal. All subassemblies are held down against the lifting force of the upflowing sodium by holddown devices located in the bottom of the subassemblies. (Figs. 29 and 30.)

The reactor vessel is a cylindrical stainless steel tank, 9 feet in diameter and 37 feet high having one-half-inch-thick walls. The walls are protected from thermal shock by a single thin steel baffle. A fixed shield plug seals off the reactor vessel. The plug has a central penetration which contains the control rod drives during operation and the fuel handling mechanism during fuel reloading. A second penetration in the plug is for the fuel exit elevator. (Fig. 29.)

Heat is removed from the core and blanket by the circulation of sodium coolant slightly pressurized in three coolant loops. (Fig. 31.) Sodium at $650^{\circ} \mathrm{F}$. enters at the bottom of the reactor vessel, flows upward, through and around the subassemblies to a sodium pool above the reactor. It leaves the reactor at $1,000^{\circ} \mathrm{F}$., flowing to three intermediate heat exchangers, then through the pumps and back into the reactor vessel. To assure against loss of coolant, the pipes and reactor vessel are provided with double containment. The primary sodium system components are located around the reactor vessel but separated from it by the main shielding wall consisting of alternate layers of iron oxide, serpentine and concrete, each encased in steel. (Figs. 27 and 28.) The shield is cooled 
by the forced flow of the below-floor atmosphere (air depleted in oxygen) between the layers. The shield wall is located at a distance of 8 feet from the reactor vessel. Within this space, the primary sodium coolant pipes are so arranged that streaming neutrons are attenuated before the pipes enter the equipment compartment. Beyond the shield wall, the neutron flux is at a biologically safe level.

The reactor and the associated equipment of the primary sodium system are located in the lower section of the 85-foot-diameter containment building. The shielded operating floor over the reactor divides the containment building into two sections. The primary sodium pump motors and the control rod drives are the only pieces of reactor equipment in the upper section. Access to equipment in the lower section is provided by removable plugs in the floor.

The reactor heat is transferred to the secondary sodium coolant system in the intermediate heat exchangers. The heated secondary sodium flows through pipes penetrating the containment building into three once-through sodium-to-water steam generators located in the adjacent steam generator building. From the steam generators, sodium is pumped back to the intermediate heat exchangers. A rupture disc installed on each steam generator protects the equipment from damage from a sodium-water reaction. Feedwater for the steam generators is provided by facilities located in the turbine portion of the plant.

At 3-month intervals, the reactor is shut down for a 3-day period in order to replace spent subassemblies with fresh ones. After shutdown and an initial decay period, the control rod drives are removed remotely by over- head cranes and the fuel handling mechanism is placed into the central penetration through the pling. A spent subassembly is lifted out of the core by the remotely operated handling mechanism and placed into a vacant storage space in the outer blanket where it is allowed to decay for 3 months. A fresh subassembly is brought from the transfer rotor, located at the edge of the containment building, in a sodium filled finned pot, and lowered through the fuel exit elevator port into the reactor vessel. The fuel handling mechanism then places the fresh subassembly into the core. Next a spent and decayed subassembly from the previous unloading is taken from its storage space, transferred to the empty finned pot. The finned pot is then returned to the transfer rotor. The sequence is repeated until the 27 core subassemblies scheduled for replacement have been handled.

The transfer rotor accommodates 45 subassemblies. Exit ports are located on each side of the containment building wall, one being located in the fuel handling and repair building and the other inside the reactor building. Subassemblies may be transferred into or out of the containment building without sacrificing containment integrity and without affecting plant operation. Spent subassemblies are removed from the transfer rotor to the cleanup, storage, and shipping facility.

Considerable flexibility is designed into the plant. All mechanisms can be removed; all equipment, such as pump rotors, IHX tube bundles, etc., that may require maintenance and repair, are removable. Core size can be adjusted for initial startup to achieve criticality or to change power output subsequently, as desired.

The PFFBR design parameters are tabulated in appendix $B$. 


\section{CONSTRUCTION AND OPERATING SCHEDULES}

\section{Experimental Breeder Reactor No. 2}

The schedule for EBR-II, shown in figure 1 in appendix $\mathrm{C}$, indicates criticality in December 1960. Time lost during construction of the containment building has been made up by expediting the remaining schedule.

\section{Enrico Fermi Atomic Power Plant}

The Enrico Fermi schedule, shown in figure 2 in appendix $\mathrm{C}$, can be met if the remaining critical items, such as steam generators and fuel subassemblies, are shipped on schedule. The test facility operation (reactor vessel, plug, handling mechanisms, two safety rod drives, one primary loop) will go into operation in July 1959 , and continue operation to the summer of 1960 . Remaining construction of EFAPP will be concurrent with test facility operation. The test facility operation will eliminate the need for a shakedown operation after start of criticality operation.

\section{Plutonium-Fueled Fast Breeder Reactor}

The schedule for this plant, shown in figure 3 in appendix $C$, has been based on a design of a second-round fast reactor plant that could be built and operated in 1965. To meet the 1965 schedule the fuel element design should be fixed in 1962. Burnup data could be available by 1962 to determine validity of basic assumptions. A reference and two alternate fuels have been evaluated, each of these being currently considered in the AEC fuel development program. The rest of the reactor plant technology is based on Fermi, EBR-I, EBRII, and Dounreay with improvements which do not affect feasibility. Prior to 1965 there will also be available the operating experience of these plants. 


\section{INHERENT PROBLEMS AND LIMITATIONS}

\section{Reactivity and Physics}

The requirement for high volumetric concentration of fissionable material in the core is an important limitation on fast breeder reactors. This limitation results in a number of problems:

(1) To hold the critical mass to reasonable limits, fairly small cores are required, resulting in high values of power density.

(2) The high power density requires small subdivision of the fuel which increases manufacturing costs.

(3) The small core size requires a high coolant temperature rise, necessitating protection against thermal shock.

(4) For any given permissible total atom burnup in the fuel, the high fuel concentration increases the number of times the fissionable isotope must go through reprocessing per unit of heat removed.

(5) The high coolant temperature rise results in steep temperature gradients in the core. This produces deformations which may require restraint to avoid undue reactivity changes.

(6) The high fast neutron flux introduces the problem of neutron damage of permanent structural material in or near the core.

In addition to the foregoing problems raised by the requirement of the high fuel consideration, there are a number of other problems:

(1) Details of the energy dependence of capture, fission, and scattering cross sections for fuel, fertile, coolant and structural materials and fission products are not as well known as would be desirable over the wide range of neutron energies present in a fast reactor. At present, this is particularly true for the value of alpha, the capture-to-fission ratio, for the three nuclear fuels. The value of $\mathrm{s}$, particularly for $\mathrm{U}^{233}$ and $\mathrm{Pu}$, is not well known.

(2) The large ratio of maximum-to-average heat generation in the radial blanket of a fast reactor gives rise to difficult coolant distribution problerns.

\section{Fuel and Materials}

Use of $\mathrm{PuO}_{2}-\mathrm{UO}_{2}$ fuel has uncertainties needing resolution. The thermal expansion properties of the compact need to be known better to determine core stability. The relatively low $\beta$ for $\mathrm{Pu}$ fuels requires careful evaluation. Gas evolution of $\mathrm{PuO}_{2}-\mathrm{UO}_{2}$ compacts requires further study, test and evaluation. Due to low thermal conductivity of oxides, heat transfer problems of such fuels become aggravated and require extensive research and development. Dilute $\mathrm{Pu}$-fueled critical assemblies have not been operated, requiring a new series of ZPR-type assemblies for $\mathrm{Pu}$ fuels. Burnup data is meager.

Fuel cycle costs, including fabrication and processing, have a declining exponential relationship between burnup and costs per kilowatthour. For example, at 2 percent burnup a fuel cycle may cost 8 mills per $\mathrm{kw} \mathrm{hr}$, while at 14 percent burnup the cost would be down to 2.5 mills per $\mathrm{kw} \mathrm{hr}$. High burnups are needed.

Stainless clad for plutonium fuels is adequate up to $1,200^{\circ} \mathrm{F}$. For service above this temperature, the development of cladding materials, such as molybdenum, is needed.

Economics (inventory-wise) and heat generation problems dictate that higher burnup of blanket elements become a prime objective. A program should be initiated to study partial thermalization of the blanket, and the use of 
larger cores to achieve higher internal breeding ratio.

A method to detect and locate a leaking fuel element is needed.

\section{Fuel Handling}

To reduce cost of fuel handling and fuel decay facilities, the following studies and developments are needed:

Operation of mechanisms in sodium at refueling temperatures $400^{\circ} \mathrm{F}$. or greater.

Use of heavier loads for mechanisms in sodium.

Inexpensive means to either live with oxide and fog formation or to eliminate them.

Fuel decay facilities less expensive than those now based on water technology.

Simplified design of subassemblies to improve disassembly.

Improved shipping methods including shipping cask standardization.

Scanning under sodium to facilitate inspection, minor repair, and location.

Improved methods of cooling subassemblies on removal from the reactor.

Improved remote maintenance techniques or elimination of need for remote maintenance.

\section{Heat Transport}

Present better understanding of thermal transients effects and resultant stresses has reduced this problem considerably but further research and development in this area is needed.

Use of greater than $1,000^{\circ} \mathrm{F}$. components may reduce capital costs. This requires mass transport and corrosion material data above $1,000^{\circ} \mathrm{F}$., and testing of such items as heat exchangers and steam generators above this temperature.

Elimination of secondary sodium systems is desirable costwise.

Better understanding of reactor shutdown cooling by analytical means, supplemented by tests, is necessary to reduce the shutdown cooling system costs.
A better understanding of sodium vapor behavior at various temperatures and flow conditions can only be obtained by tests.

\section{Safety}

Very large increases in reactivity may result if a fast reactor core were compacted due to melting the agglomeration. This is the largest safety limitation on fast reactors. This limitation results in problems in three areas, viz: that of design measures taken to prevent melting, that of design measures taken to prevent agglomeration, and that of design measures taken to contain the nuclear energy release which might occur should steps taken in the first two areas prove inadequate. Some of these problems which pertain to any reactor system are:

(1) The heat removal system must have high integrity to prevent loss of cooling ability.

(2) Experimental and theoretical investigations need to be made of the probable behavior of the fuel upon melting, and the possibility considered of providing design features to prevent agglomeration in case of melting.

(3) Careful and conservative estimates of the maximum credible energy release in case of melting and agglomeration are necessary.

(4) Due to the high coolant activity present when sodium is the coolant, detection in situ of a leaking fuel or blanket element is difficult.

(5) The large amount of fuel normally present in a core subassembly requires that shipping and handling procedures for core subassemblies be carefully studied to prevent criticality accidents during manufacture, shipping, or storage.

(6) The high power density requires that great care be taken to prevent melting of core subassemblies due to decay heating during transfer and shipping operations.

Some problems that pertain particularly to fast reactors are: 
(1) Due to the small values of the prompt neutron lifetime, and small temperature coefficients of reactivity, and, for the case of plutonium or $\mathrm{U}^{233}$, the small value of the delayed neutron fraction, great care must be taken in the design to assure that no credible control mal-operation or oscillatory instability can result in fuel melting.

(2) The possibility of positive temperature or power coefficients due to core thermal distortion or due to nuclear effects must be rigorously investigated for each design. Thermal testing is necessary.
Some problems that pertain to all sodiumcooled reactors are:

(1) Cooling system must be designed to prevent inleakage of hydrogeneous materials which could cause large reactivity increases. The fuel loading scheme must be designed to prevent accidents caused by safety rod override.

(2) The use of sodium for cooling requires that adequate provisions be taken to prevent and contain fires or reactions with the thermodynamic fluids. 


\section{Appendix A}

\section{DATA ON REACTORS UNDERWAY}

\section{Description}

Experimental Breeder Reactor II.-The EBR-II is an unmoderated, heterogeneous, sodium-cooled fast breeder reactor and powerplant with a power output of $62.5 \mathrm{Mw}$ of heat, and $20 \mathrm{Mw}$ gross of electricity, fueled with $\mathrm{U}^{235}$ or plutonium, to be constructed at the National Reactor Testing Station in Idaho.

Enrico Fermi Atomic Power Plant.-The Fermi plant is an unmoderated, heterogeneous, sodium-cooled fast breeder reactor and power plant designed for $430 \mathrm{Mw}$ of heat and $156 \mathrm{Mw}$ gross of electricity (type B core), with an initial power output of $300 \mathrm{Mw}$ of heat and 104 Mw gross of electricity (type A core), fueled with $\mathrm{U}^{235}$, to be constructed on Lake Erie at
Lagoona Beach in Frenchtown Township, Mich., 30 miles southeast of Detroit, Mich.

\section{Purpose}

$E B R-I I$ - This reactor is primarily a flexible experimental engineering facility to determine the feasibility of this type of reactor for central station power plant application, with major emphasis on achieving high thermal performance at high temperatures, high fuel burnup with a fast and economical fuel cycle, efficient breeding, pyrometallurgical processing, and remote fabrication.

Enrico Fermi.-This plant is a developmental, full-size power breeder reactor being built as an essential step in the commercial development of economical nuclear power.

\section{Design Parameters}

Fuel and coolant:

Fuel.

Primary system coolant

Secondary system coolant

Turbine system coolant.

Moderator

Thermal power rating, kwt

Electrical power rating, kwe:

Gross

Net

Thermal efficiency, percent:

Gross

Net.

See footnotes at end of table.
Enrico Fermi

EBR-II

\begin{tabular}{r|r|r} 
& \multicolumn{2}{|c}{ Enrico Fermi } \\
\cline { 2 - 3 } U235 & \multicolumn{1}{|c}{ Type A core 1 } & Type B core \\
\hline Sodium & $\mathrm{U}^{235}$ & $\begin{array}{r}\text { U235 } \\
\text { Sodium }\end{array}$ \\
Sodium & $\begin{array}{r}\text { Sodium } \\
\text { Sodium }\end{array}$ \\
None & Sodium & Water/steam \\
62,500 & Water/steam & None \\
& None & 430,000 \\
20,000 & 300,000 & \\
17,400 & & 156,000 \\
32.0 & 104,000 & 146,000 \\
27.9 & 94,000 & 36.3 \\
& 34.7 & 33.9
\end{tabular}


Design Parameters-Continued

\begin{tabular}{|c|c|c|c|c|c|c|}
\hline & \multirow{2}{*}{\multicolumn{3}{|c|}{ EBR-II }} & \multicolumn{3}{|c|}{ EFAPP } \\
\hline & & & & \multicolumn{2}{|c|}{ Type A core ${ }^{1}$} & Type B core \\
\hline $\begin{array}{l}\text { Temperatures, }{ }^{\circ} \text { F.: } \\
\text { Reactor inlet }\end{array}$ & \multirow{2}{*}{\multicolumn{3}{|c|}{700}} & \multirow{2}{*}{\multicolumn{2}{|c|}{550}} & 600 \\
\hline & & & & & & \\
\hline Reactor outlet.-... & \multicolumn{3}{|r|}{890} & \multicolumn{2}{|r|}{800} & 900 \\
\hline Steam generator $\mathrm{Na}$ inlet. $\ldots \ldots$ & \multirow{2}{*}{\multicolumn{3}{|c|}{$\begin{array}{l}870 \\
610\end{array}$}} & \multicolumn{2}{|r|}{750} & \multirow{2}{*}{$\begin{array}{l}820 \\
520\end{array}$} \\
\hline Steam generator $\mathrm{Na}$ outlet......... & & & & \multicolumn{2}{|r|}{500} & \\
\hline Feedwarer temperature & \multicolumn{3}{|r|}{550} & \multicolumn{2}{|r|}{$\begin{array}{l}340 \\
486\end{array}$} & $\begin{array}{l}380 \\
532\end{array}$ \\
\hline Saturated steam temperature & \multicolumn{3}{|r|}{580} & \multirow{2}{*}{\multicolumn{2}{|c|}{$\begin{array}{l}486 \\
742\end{array}$}} & 532 \\
\hline Superheated steam temperature & \multirow{2}{*}{\multicolumn{3}{|c|}{$\begin{array}{r}840 \\
1,250\end{array}$}} & & & \multirow{2}{*}{$\begin{array}{l}780 \\
900\end{array}$} \\
\hline Steam pressure, psig & & & & \multirow{2}{*}{\multicolumn{2}{|c|}{600}} & \\
\hline Core size: & \multicolumn{3}{|r|}{1,250} & & & \\
\hline Equiv. diameter, inches $\ldots$ & & & 19.04 & & 29 & 36 \\
\hline Length, inches & & & 14. 22 & & 30.5 & 30.5 \\
\hline Volume, cu ft & & & 2. 32 & & 11.65 & 17. 75 \\
\hline Power density, $\mathrm{kwt} / \mathrm{ft}^{3}$ core: & & & & & & \\
\hline Maximum & & & 35,000 & & 44,170 & 31,000 \\
\hline Average & & & 22,800 & & 23, 000 & 21,500 \\
\hline Core power, kwt & & & 53,000 & & 268,500 & 384,000 \\
\hline Power density maximum to average ratio & & & 1.53 & & 1.79 & 1. 44 \\
\hline Initial fuel enrichment, percent $U^{236}$ & & & 49. 4 & & 25. 6 & 93 \\
\hline Conversion ratio: & & & & & & \\
\hline Core & & & $\begin{array}{l}0.30 \\
0.90\end{array}$ & & $\begin{array}{l}0.30 \\
0.90\end{array}$ & $\begin{array}{r}0.40 \\
0.70\end{array}$ \\
\hline Blanket & & & & & & \\
\hline Total _..... & & & 1. 20 & & 1.20 & 1. 10 \\
\hline Specific power, $k w t / k g U^{235} \ldots$ & & & 314 & & 605 & 894 \\
\hline $\begin{array}{l}\text { Maximum fuel temperature, }{ }^{\circ} \mathbf{F} \text {. (including un- } \\
\text { certainty factors) }\end{array}$ & & & 1,320 & & 1,235 & 1,325 \\
\hline Core inventory, $\mathrm{kg} \mathrm{U} \mathrm{U}^{235}$ & & & 170 & & 444 & 430 \\
\hline$\Delta \mathrm{T}$ across core, ${ }^{\circ} \mathbf{F}$ & & & 190 & & 250 & 300 \\
\hline Average heat flux, Btu/ft' ${ }^{2}$ hr & & & 80,000 & & 652,000 & 675,000 \\
\hline Maximum heat flux, Btu/ $\mathrm{ft}^{2}-\mathrm{hr}$ & & & 30,000 & & $1, \mathbf{1 6 6 , 0 0 0}$ & $1,167,000$ \\
\hline Control: & & & & & & \\
\hline Number of control safety rods... & & & 2 & & 8 & 8 \\
\hline Number of control operating rods & & & 12 & & 2 & 2 \\
\hline Type of control & & & Fuel & & $\left({ }^{2}\right)$ & $\left({ }^{2}\right)$ \\
\hline Reactivity worth: & $\partial K / K$ & & $N H R$ & & NHR & \\
\hline Operating-- & 0.046 & 6. 30 & 1,530 & 0.0067 & $0.92 \quad 255$ & \\
\hline Safety...- & 0.014 & 1. 92 & 535 & 0.0584 & 8. $00 \quad 2,230$ & (3) \\
\hline Total & .060 & 8. 22 & 2,065 & .0651 & 8. $92 \quad 2,485$ & \\
\hline Reactivity effects: & & & & & & \\
\hline Burnup & 0.011 & 1.51 & 420 & 0.0024 & 0.33 & \\
\hline Fission product buildup . . & 0.002 & 0.27 & 75 & 0.0002 & 0.02 & \\
\hline Growth & 0.011 & 1. 51 & 420 & 0.0005 & 0.07 & $\left({ }^{3}\right)$ \\
\hline Temperature override & 0.003 & 0.41 & 115 & 0.0015 & 0.20 & \\
\hline Total. . & 0.027 & 3. 70 & 1,030 & 0.0046 & 0.62 & \\
\hline
\end{tabular}




\section{Cross-Section and Views}

EBR-II-Figures 9 through 15.

EFAPP-Figures 16 through 26.

\section{Operating Considerations}

\section{Activity levels in Fermi}

Primary sodium coolant $\mathrm{Na}^{24}, \mathrm{Na}^{22}$.

At full power $\mathrm{Na}^{24}, 0.043$ curie/cc.

After shutdown: $\mathrm{a}^{22}, 1.7$ micro-

For 1 day 0.015 curie/cc.

For 7 days. 19 microcuries/cc.

For 10 days 1.7 microcuries/cc.

Secondary sodium coolant $\left(\mathrm{Na}^{24}\right)$ :

At full power. $1.5 \times 10^{-1} \mu \mathrm{c} / \mathrm{cc}$. After shutdown:

For 1 day. $5.3 \times 10^{-5} \mu \mathrm{c} / \mathrm{cc}$.

For 7 days. $6.7 \times 10^{-8} \mu \mathrm{c} / \mathrm{cc}$.

For 10 days $2.5 \times 10^{-9} \mu \mathrm{c} / \mathrm{cc}$.

Primary cover gas $\mathrm{A}^{41}$ (at STP):

Over reactor at full power.... $\ldots 146 \mu \mathrm{c} / \mathrm{cc}$. After shutdown:

For 1 hour. $98 \mu \mathrm{c} / \mathrm{cc}$.

For 12 hours $1.5 \mu \mathrm{c} / \mathrm{cc}$

For 1 day $0.015 \mu \mathrm{c} / \mathrm{cc}$.

For 2 days

$2.3 \times 10^{-1} \mu \mathrm{c} / \mathrm{ce}$.

In exit port:

At full power $0.95 \mu \mathrm{c} / \mathrm{cc}$

After 1 hour

$0.65 \mu \mathrm{c} / \mathrm{cc}$.

After 12 hours

$0.01 \mu \mathrm{c} / \mathrm{cc}$.

Nitrogen gas coolant in lower compartment:

Highest inner compartment activity.

Average activity at full power (STP) in lower building atmosphere.

Activity at full power at heat exchangers: Outside building (STP).

Waste gases before disposal (from subassemblies cleaning operation):

\section{Before dilution}

Highest expected contamination_ $0.006 \mu \mathrm{c} / \mathrm{cc}$.

Normally expected: no higher $1 \times 10^{-5} \mu \mathrm{c} / \mathrm{cc}$. than-

Discharge concentration $2 \times 10^{-8} \mu \mathrm{c} / \mathrm{cc}$.
Waste liquids before disposal (from subassembly cleaning operations):

Greatest expected contamination of $\mathrm{Na}$ clinging to fuel subassemblies.

Discharge concentration _ _ _ $8 \times 10^{-9} \mu \mathrm{c} / \mathrm{cc}$.

Storage pool: Highest water $8 \times 10^{-4} \mu \mathrm{c} / \mathrm{cc}$. activity expected due to leak.

Miscellaneous cleaning operations estimated contamination highest expected :

Decontamination operationsliquid.

Hot laboratory wastes . . . . . . . $2 \times 10^{-5} \mu \mathrm{c} / \mathrm{cc}$.

Hot laundry wastes........... $3 \times 10^{-5} \mu \mathrm{c} / \mathrm{cc}$

Solid hardware activity (from subassemblies, etc.) :

Stainless steel from core and 0.1 to 20 curies/ce. blanket regions.

Stainless steel within vessel _ _ _ 0.1 to 0.3 curie/ce.

\section{Activity of steel on primary sodium}

Components in equipment com- $1 \times 10^{-6} \mu \mathrm{c} / \mathrm{cc}$. partment.

After operation at full power:

Fuel subassemblies $\gamma=$ activity per subassembly:

Inner row ( 1 percent) at $1 \times 10^{5}$ curies. $300 \mathrm{BU} \mathrm{Mw}$.

Outer row ............... $8 \times 10^{4}$ curies.

Axial blanket subassembly, 700 curies. activity per subassembly.

Radical blanket subassembly, $1.4 \times 10^{4}$ curies. activity per subassembly.

\section{Equipment Problems}

Mechanical effects.-Galling of threads, sliding and mating parts presents some mechanical problems. Sodium is a poor lubricant and prevents formation of oxide films that could inhibit galling. Loose running fits, tapered threads, high finish surfaces, and surface treatment, such as nitriding, are design methods to eliminate galling. More development of nitriding for application to sodium components is necessary. Diffusion bonding is also a problem and is treated in like manner.

Remote maintenance equipment--Remote maintenance of radioactive equipment is a problem requiring considerable development. Remote handling without shielding is a must, 
requiring ingenious designs. Prevention of oxide formation is important if steam cleaning is to be used and the equipment is to be placed back in service.

Fuel handling mechanisms.-Bearing loads in sodium will be evaluated under test. Present load limitations are low and need to be increased.

Foolproof devices to prevent hangup of fuel on transfer are essential and require considerable preoperational testing.

Calibration of handling devices in hot gas is necessary since there is no mechanism available to locate fuel under sodium.

Radioactive inert gas handling.-The Fermi gas-handling system is quite complex and will require considerable testing and possible redesign to simplify, prior to radioactive operation.

Cover gas.-The cover gas is argon. Nitrogen is less expensive, and fission gases can more easily be separated from it, but nitriding problems at interfaces require further research and development.

Steam generator - Once-through. - The Fermi once-through steam generator is the first of its kind in nuclear use. Considerable testing has been done on models, but only actual practice will prove its ability in nuclear plants to effectively produce superheated steam in one unit, particularly with the possible rapid temperature transients.

Heating.-Induction heating and resistance heating are used. These are expensive but are used relatively little and provide an impediment to maintenance. Actual practice will indicate the need for extensive heating.

Vapor traps.-An effective vapor trap-small in size per volume of vapor is needed. Existing units are too large.

Oxide analysis equipment.-Existing equipment for analysis below 0.002 to $0.003 \mathrm{w} / \mathrm{o} \mathrm{O}_{2}$ has not been proven. Plugging indicators and analytical devices exist and are adequate above this range.

Tube sheets.-Heat exchanger and steam generator tube sheet designs, particularly the tube attachments, still present a problem and require considerable effort to improve them at low cost.

Tubes.--Methods of inspecting heat exchanger and steam generator tubes in place is needed. Inspection during construction is not adequate. Internal visual inspection of 80 foot-long tubes is not possible. Ultrasonic testing is limited. More development is needed on inspection.

Nuclear instruments.-High temperature neutron counters are being used in Fermi. Only a few sources are available in industry for such counters. Cable connections are inadequate.

\section{System Problems}

Impurities.--Oxygen, hydrogen, carbon and calcium are the prime system corrosion agents. The need to keep these down to a minimum at time of system filling and prevention of their entrance during operation presents many problems. Hydrogen is also a moderator and must be kept out of the system in any form.

System cleanliness, cold trapping, $\mathrm{NaK}$ bubblers, effective seals, minimum of lubricants, nonhydrogen containing lubricants, intermediate link between water and reactor are some of the means used to reduce or keep out impurities. Further work is necessary.

Hydrodynamic.-Hydraulic flow problems, such as mixing, oscillatory transients, and system sodium levels, require actual system operation to check out analysis and tests.

Control.-Complex water-steam flow problems intermixed with reactivity control, sodium flow control, and temperature transients require considerable analogue simulation, and finally actual system testing. Better understanding of multiloop system interactions is needed. Startup systems are also inadequately covered by today's technology. The problem of reactor prime control or steam prime control is always present. Fermi has the reactor as the prime control. 
General Maintenance

The largest technical problem is cleaning, the most difficult, remote handling, followed closely by remote maintenance. Research and development on various cleaning agents is imperative. Too little work has been done on cleaning.
Steam cleaning is predominantly used-requires extensive rycling and has the danger of chloride corrosion present. Remote maintenance tools have to be adapted for use on maintaining equipment. Exiensive monitoring systems and rinsing apparatus require development for specific uses. 


\section{Appendix B}

\section{PLUTONIUM-FUELED FAST BREEDER REACTOR DESIGN PARAMETERS}

Fuel ...................................

Primary system coolant.

Secondary system coolant...........

Turbine system coolant

Moderator -

power rating, $\mathrm{kwt}$

Electrical power rating, kwe:

Gross

Net.

Thermal efficiency, percent:

Gross

Net

Temperatures, ${ }^{\circ}$ F.:

Reactor inlet temperature

Reactor outlet temperature

Steam generator $\mathrm{Na}$ inlet temperature.

Steam generator $\mathrm{Na}$ outlet temper-

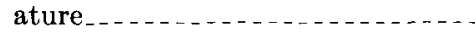

Feedwater temperature

Saturated steam temperature......

Superheated steam temperature....

Steam pressure, psia 48
$\mathrm{Pu}^{239}$ Core size:

Sodium

Sodium

Water/steam

None

775,000

300,000

283, 000

37. 7

36. 5

650

1,000

920

570

382

592

870

1,450 age
Equivalent diameter, inches ......

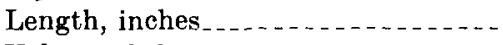

Volume, $\mathrm{ft}^{3}{ }^{3} \ldots \ldots \ldots$

Power density, $\mathrm{kwt} / \mathrm{ft}^{3}$ of core:

Maximum .........................

Average ....................

Core power, kwt. ...............

Power density ratio, maximum to aver-

Initial fuel enrichment, percent $\mathrm{Pu}^{239}$

Conversion ratio:

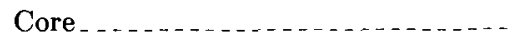

Blanket . . . . . . . . . .

Total _.......................

Specific power, kwt/kg $\mathrm{Pu}^{239} \ldots \ldots \ldots$

Maximum fuel temperature, ${ }^{\circ} \mathrm{F}$. (including uncertainty factors) ........

Core inventory $\left(\mathrm{kg} \mathrm{Pu}^{239}\right) \ldots \ldots$

$\Delta \mathrm{T}$ across core, ${ }^{\circ} \mathrm{F} \ldots \ldots$

Average heat flux, Btu/ $\mathrm{ft}^{2}-\mathrm{hr} \ldots \ldots \ldots$

Maximum heat flux, Btu/ft $\mathrm{t}^{2}-\mathrm{hr} \ldots \ldots$.
60

36

54. 2

25,350

13,000

705,000

1. 95

26

0. 30

1. 04

1. 34

1,150

4,250

674

350

337,000

657,000 
Appendix C

SCHEDULES 


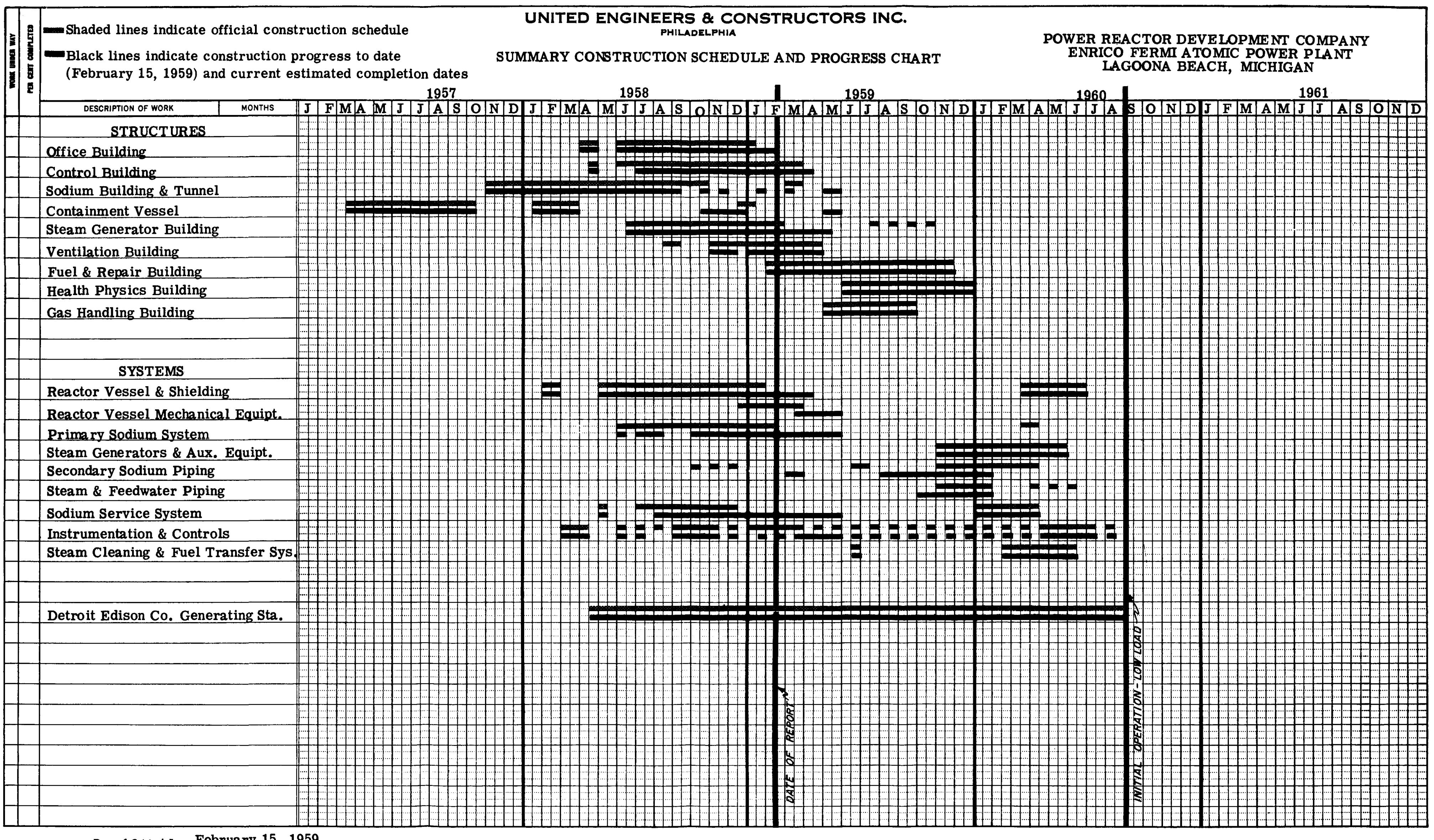




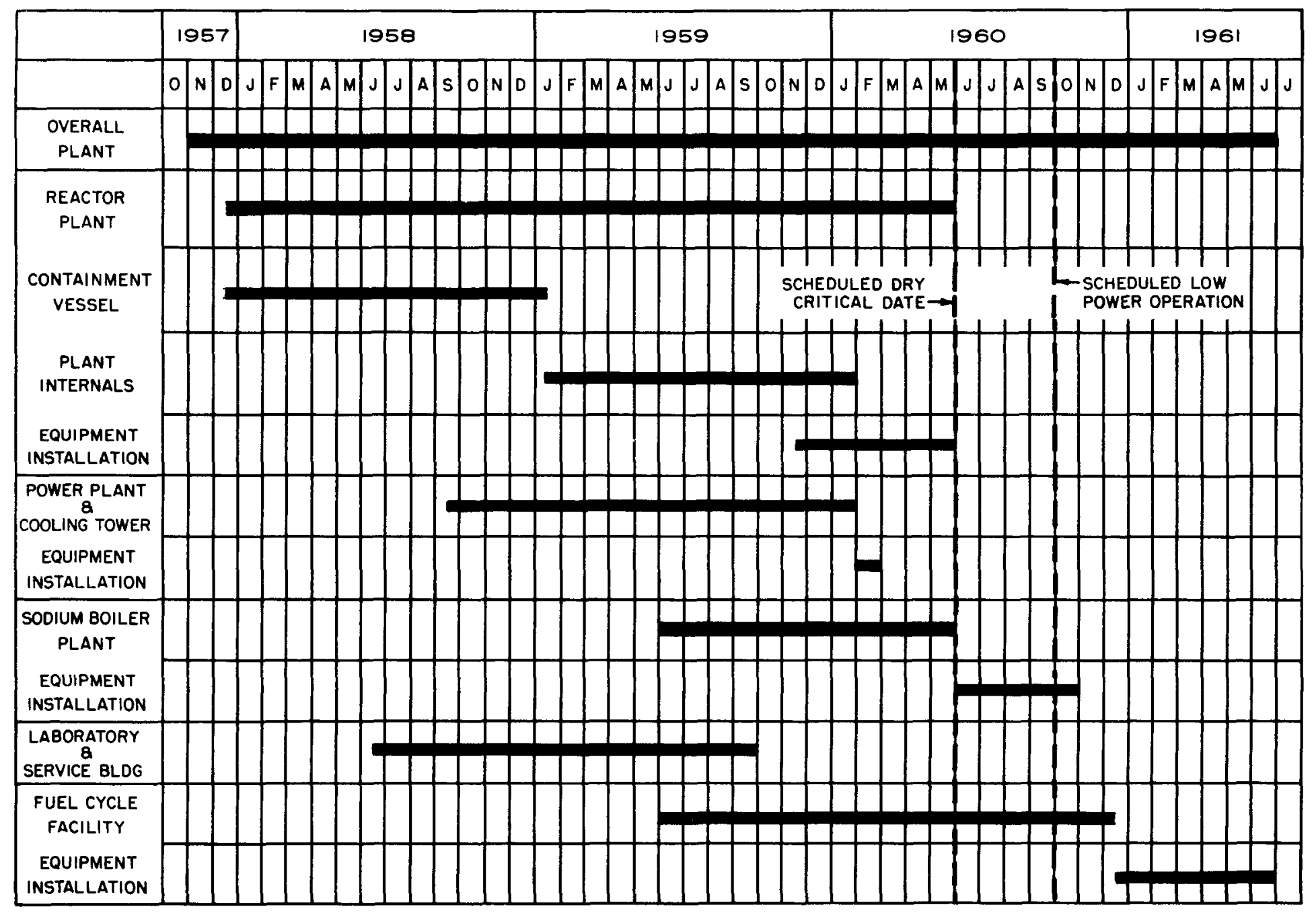

Frgure 1.-EBR-II construction and operation schedule. 


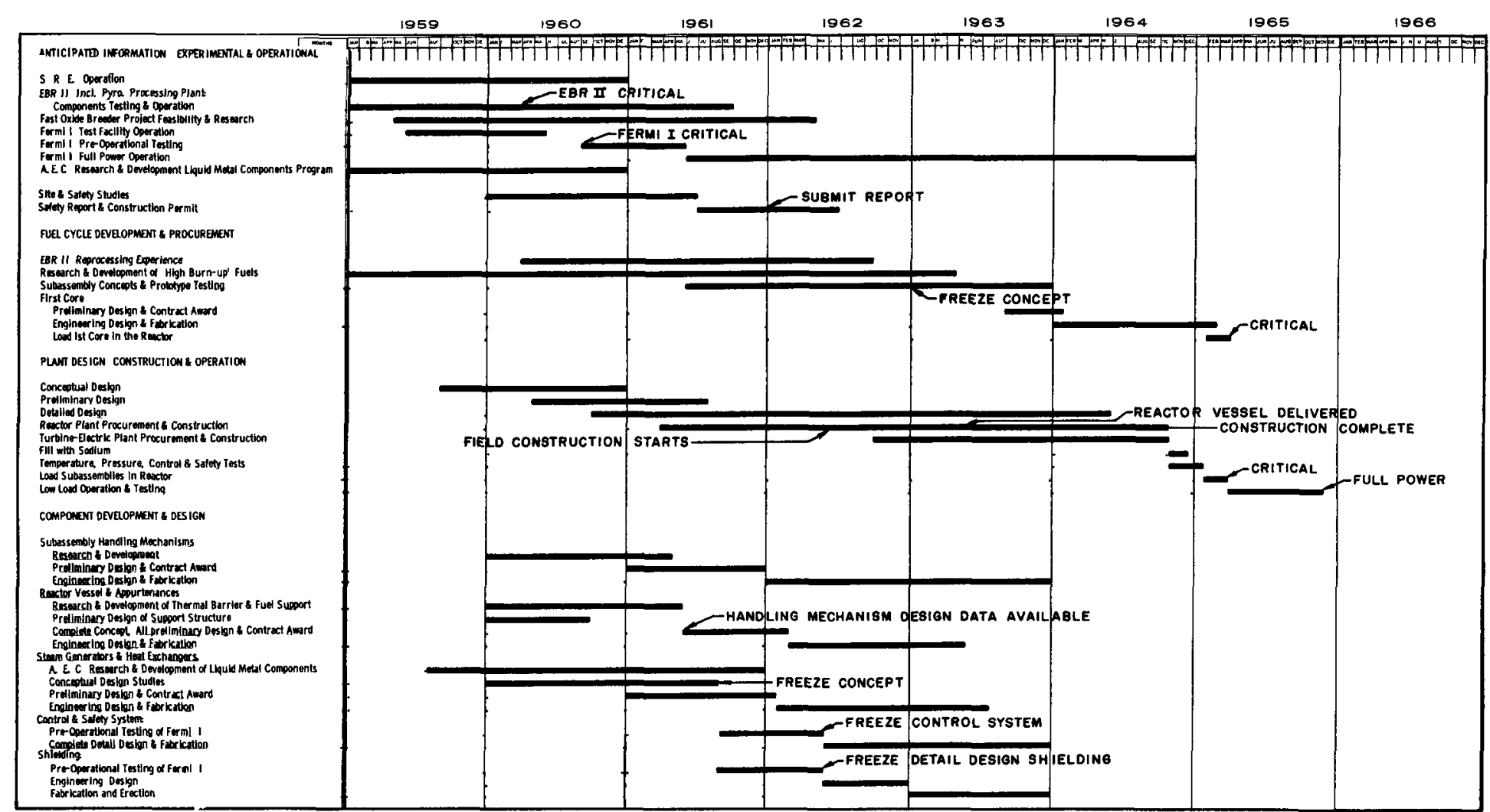

Figure 3.--Engineering design, procurement, and construction schedule for the Plutonium-fueled Fast Breeder Reactor (PFFBR). 
Appendix D

DRAWINGS 



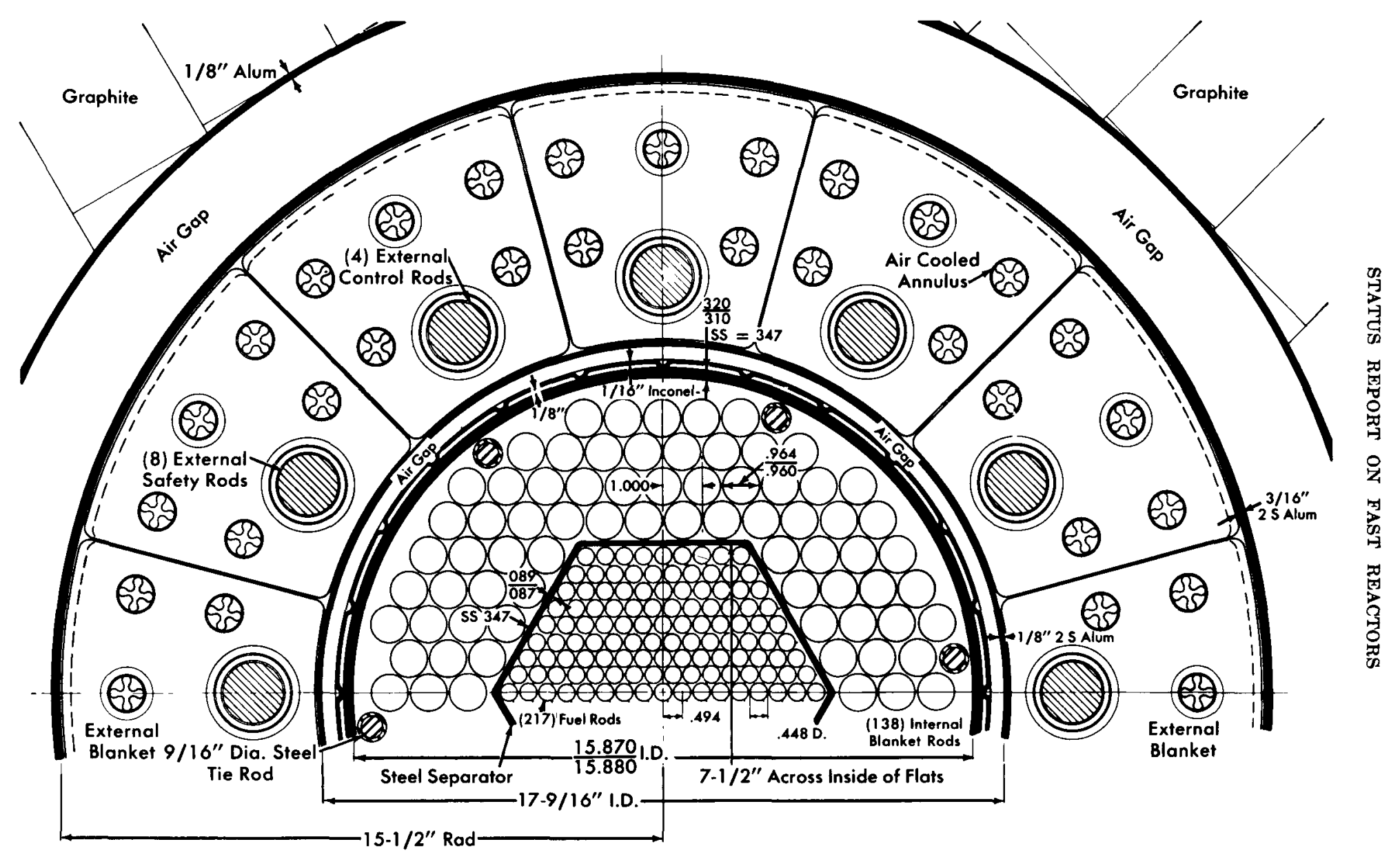

FIgure 4.-Horizontal cross section at midplane of Mark II core for FBR-I. 


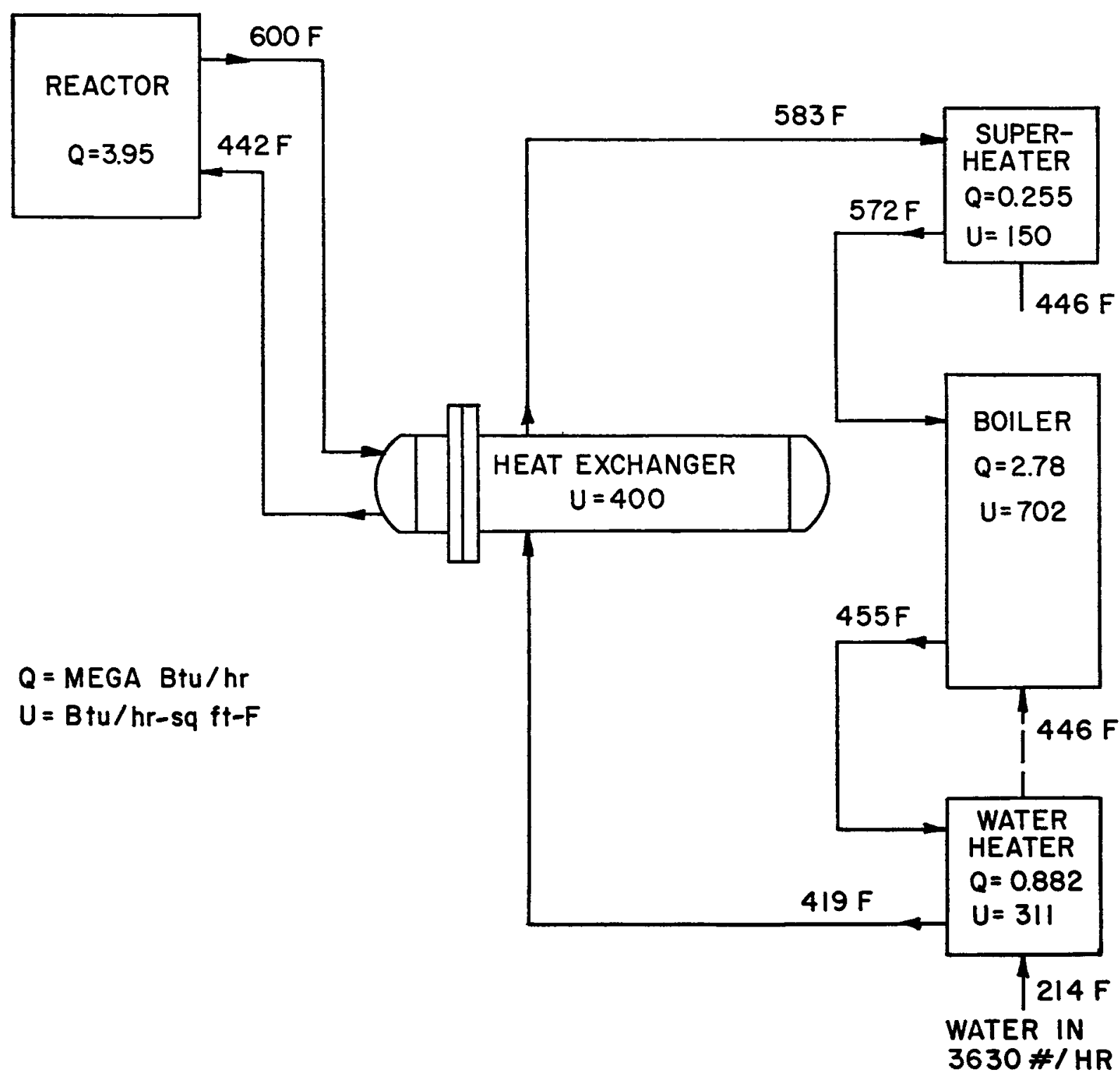

FiguRE 5.-EBR-I heat flow diagram. 

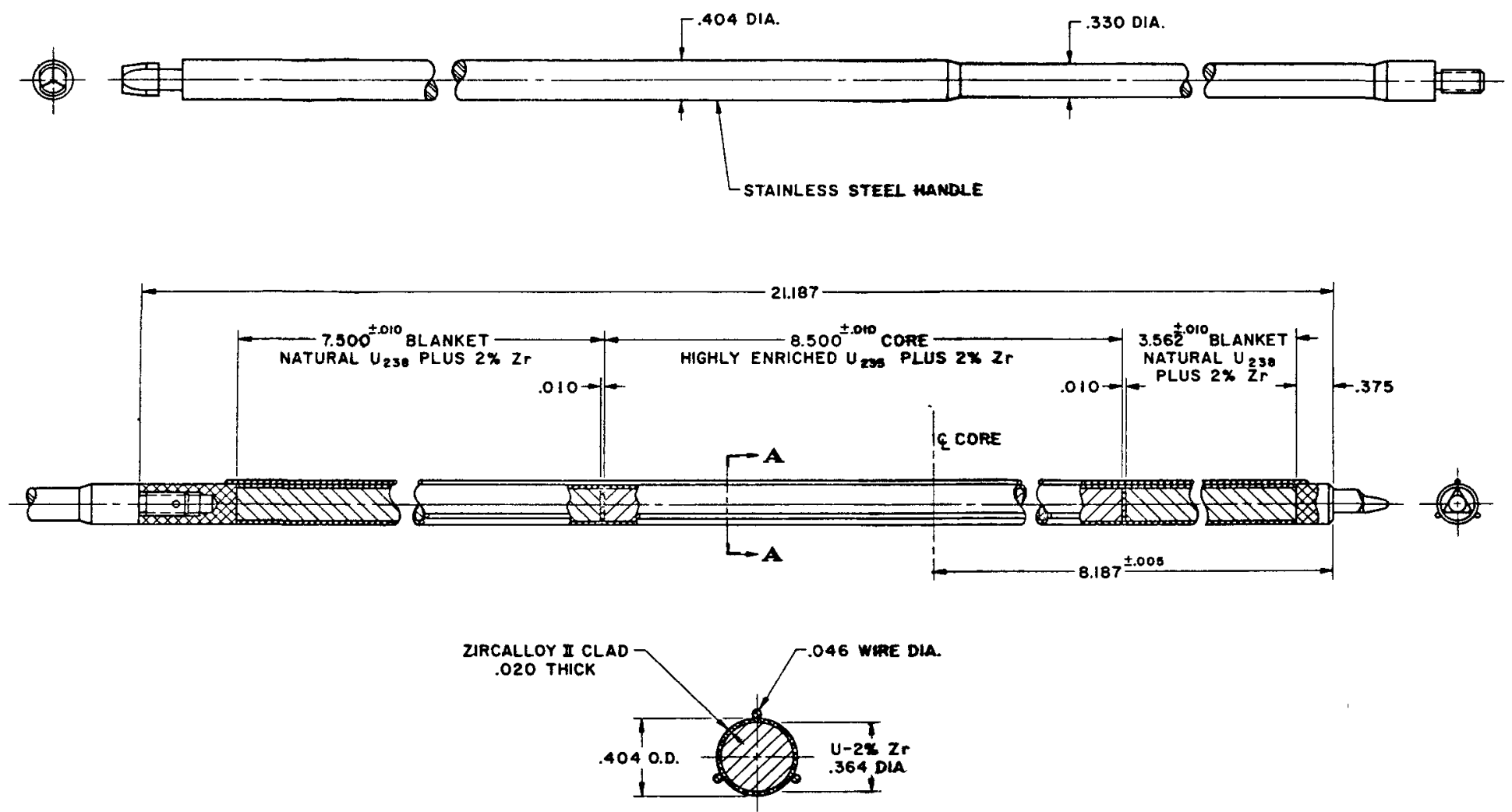

SECTION A-A

Figure 6.-EBR-I Mark III fuel rod. 


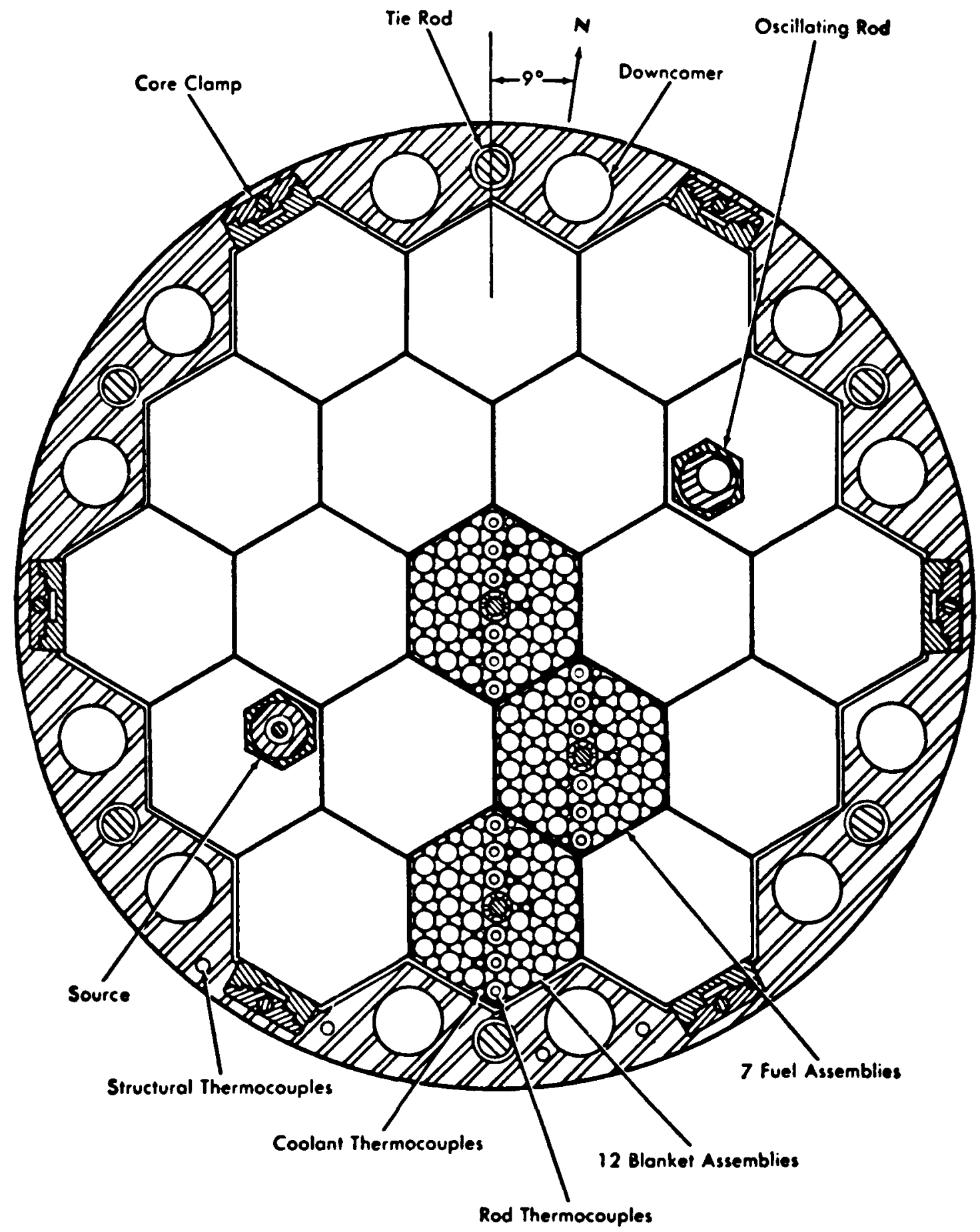

Figure 7.-EBR-I Mark III reactor cross section. 


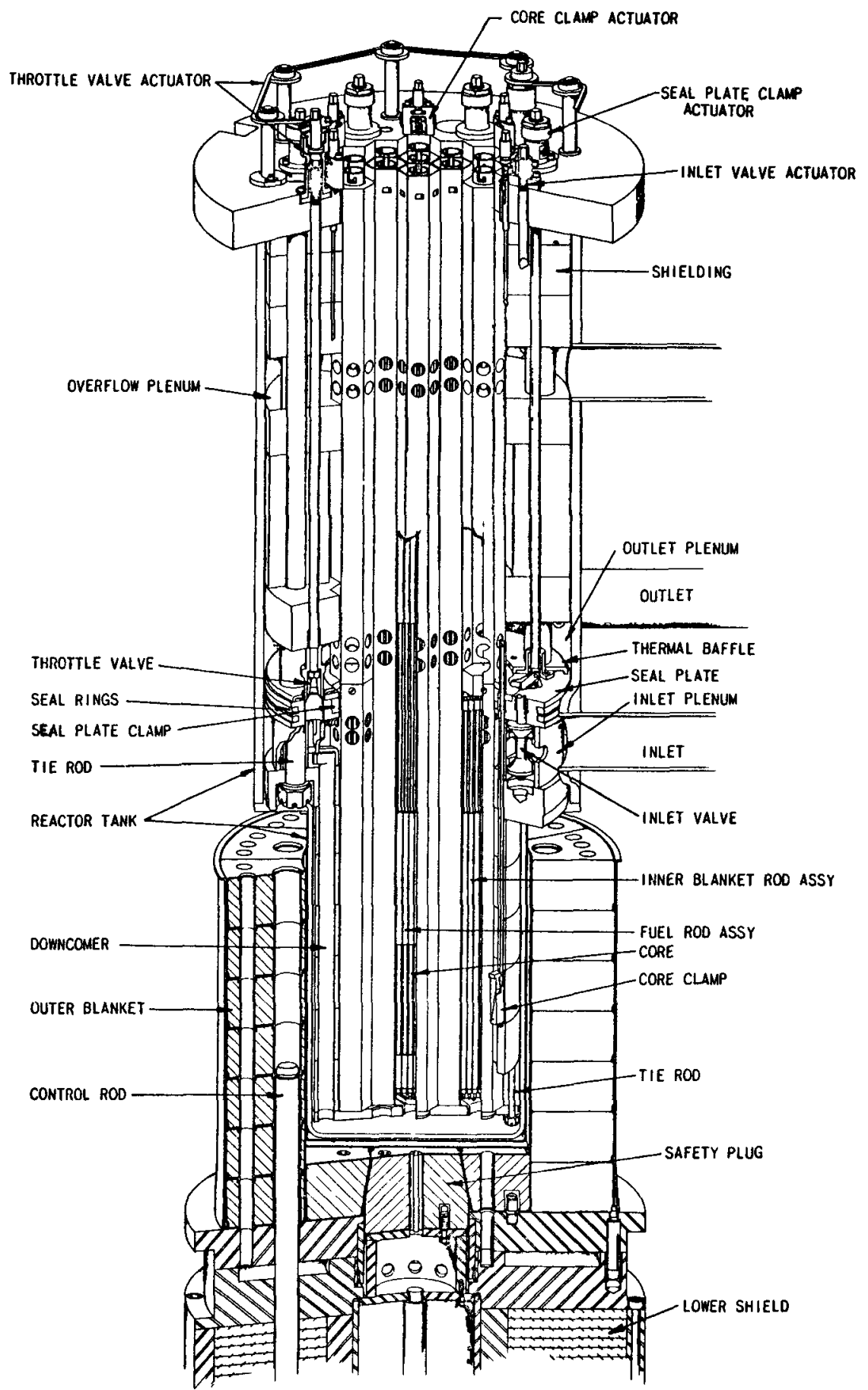

Figure 8.-EBR-I Mark III inner tank assembly. 


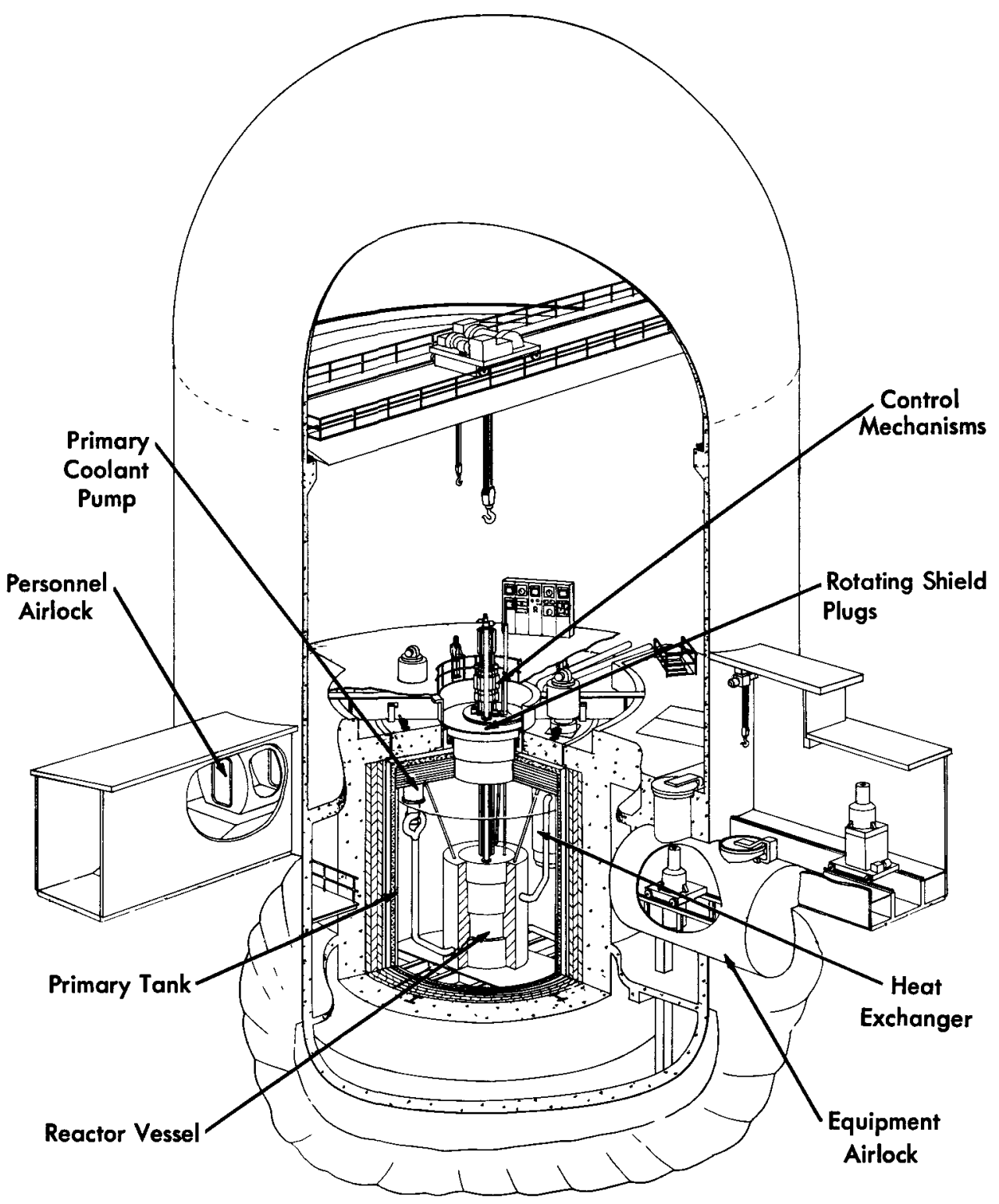

Figure 9.-Cutaway drawing of EBR-II plant. 


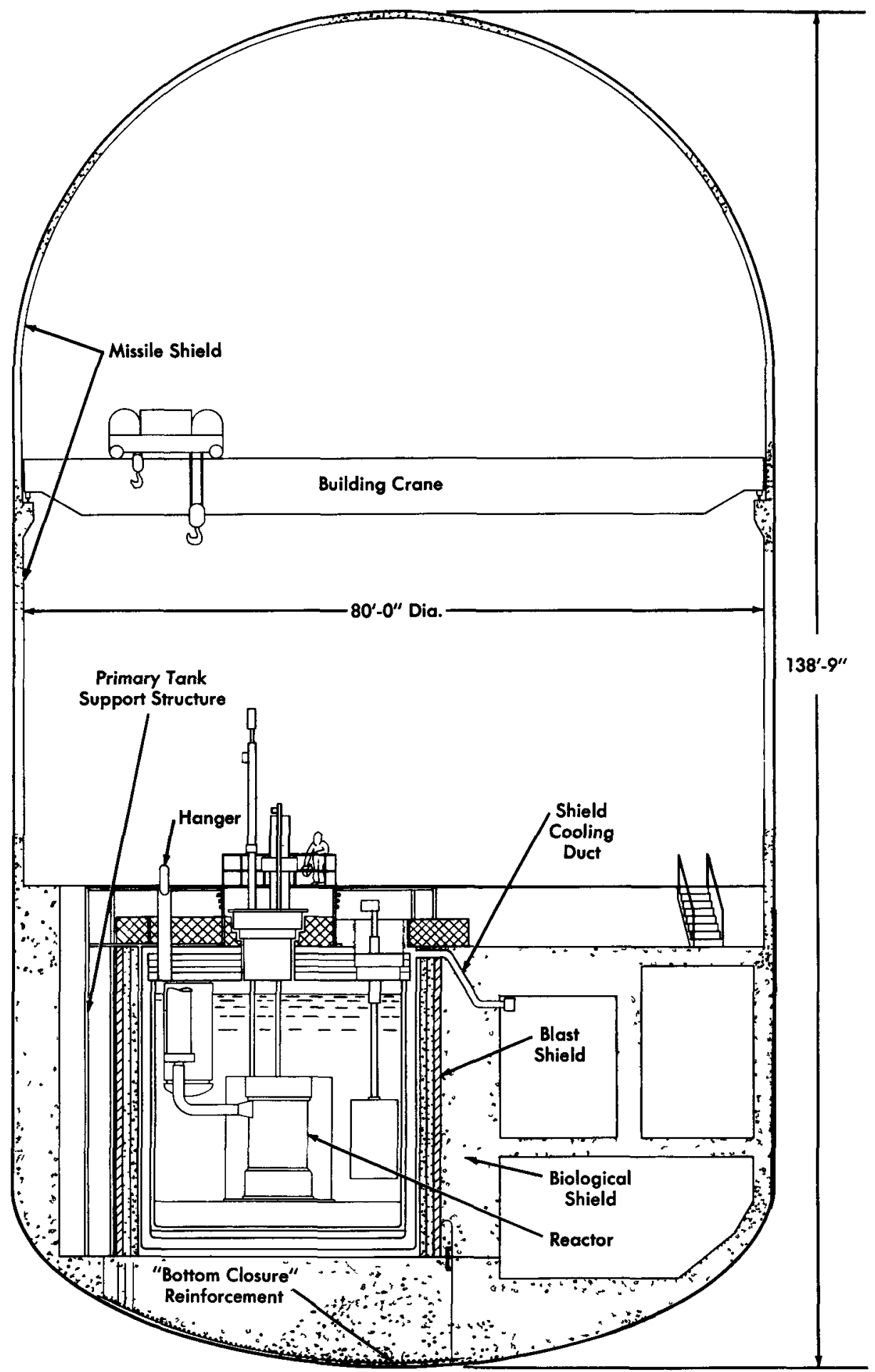

Figure 10.--Vertical section of EBR-II plant. 

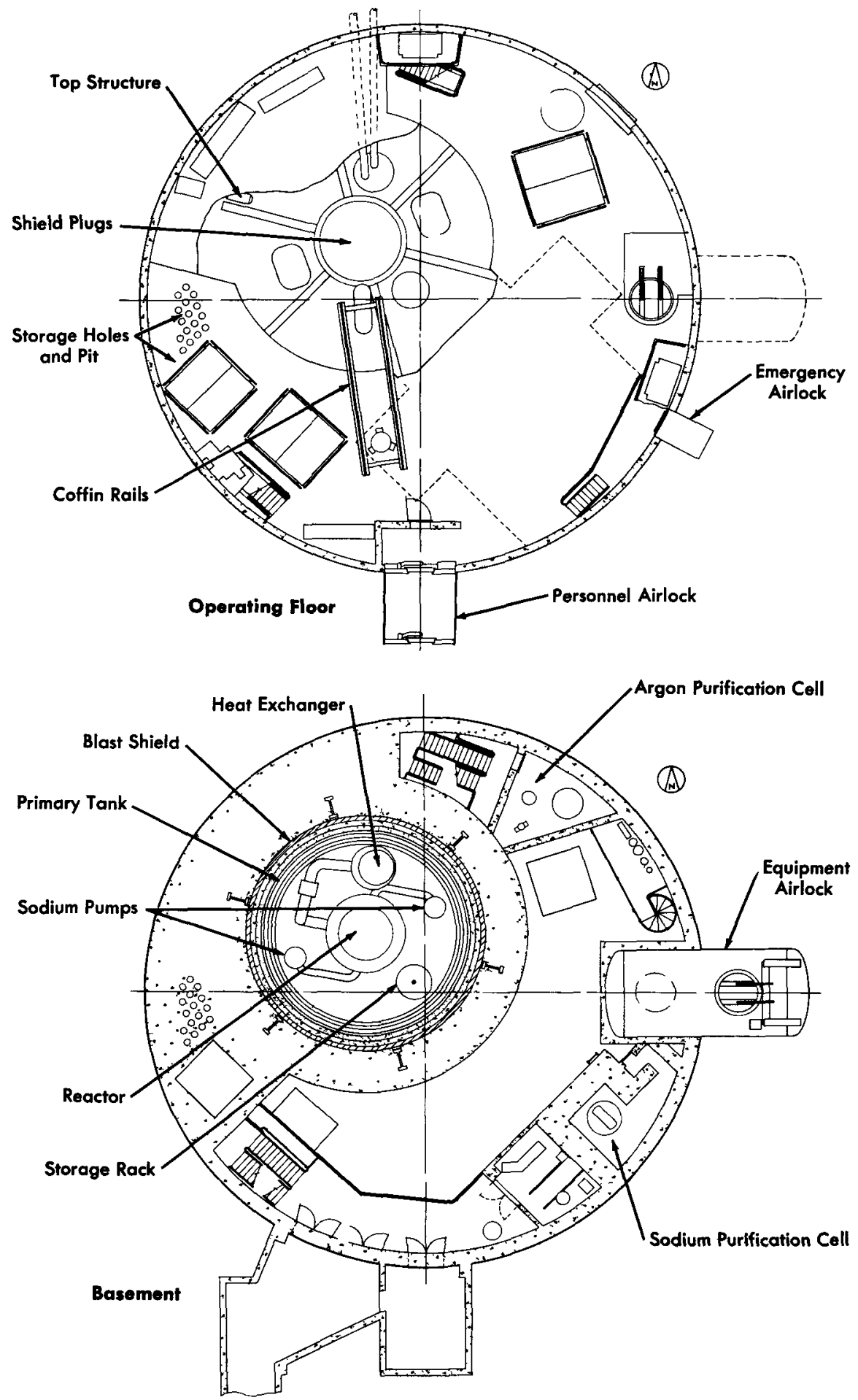

FIguRe 11.-Horizontal sections of EBR-II plant. 


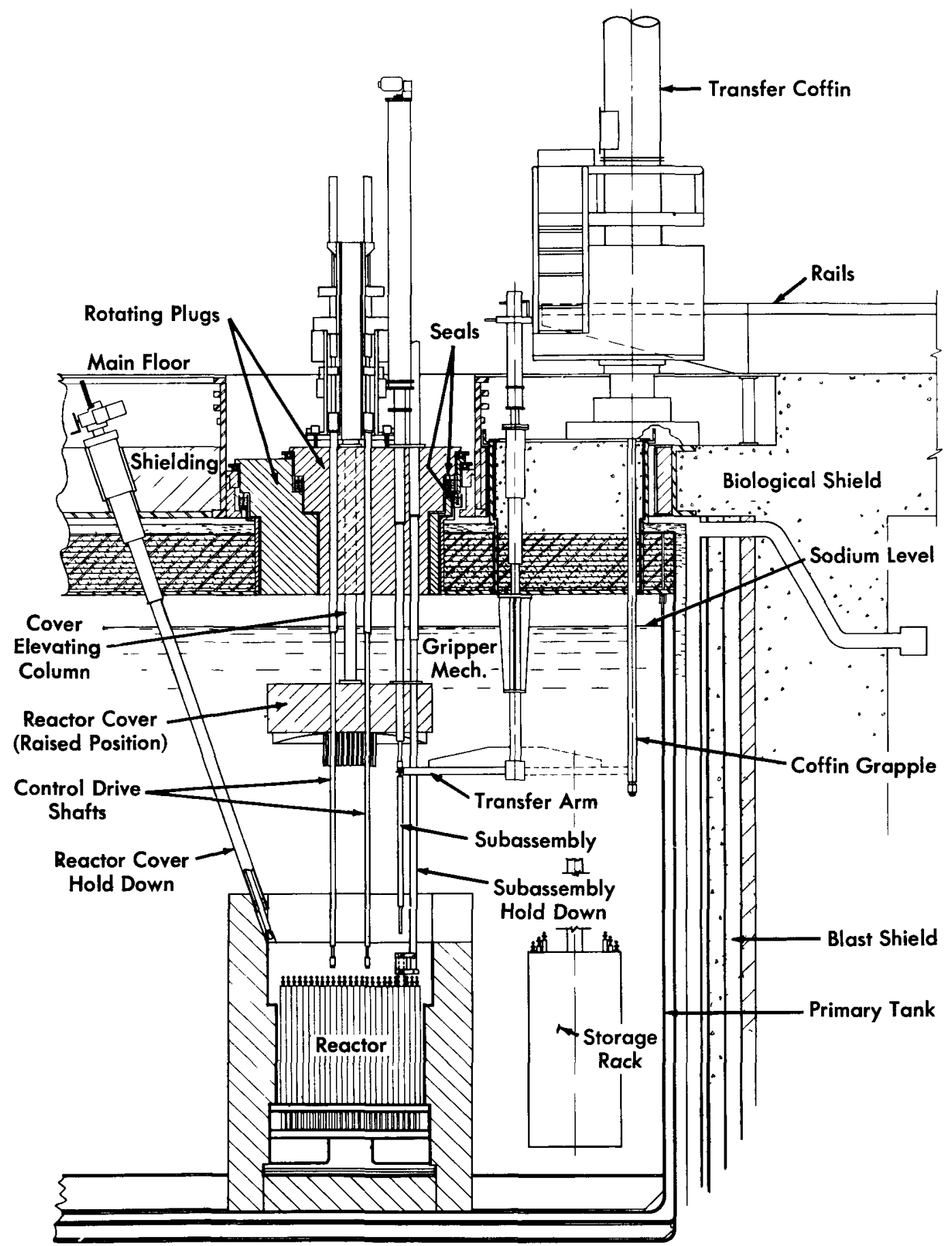

FIgURE 12.-EBR-II fuel handling system. 


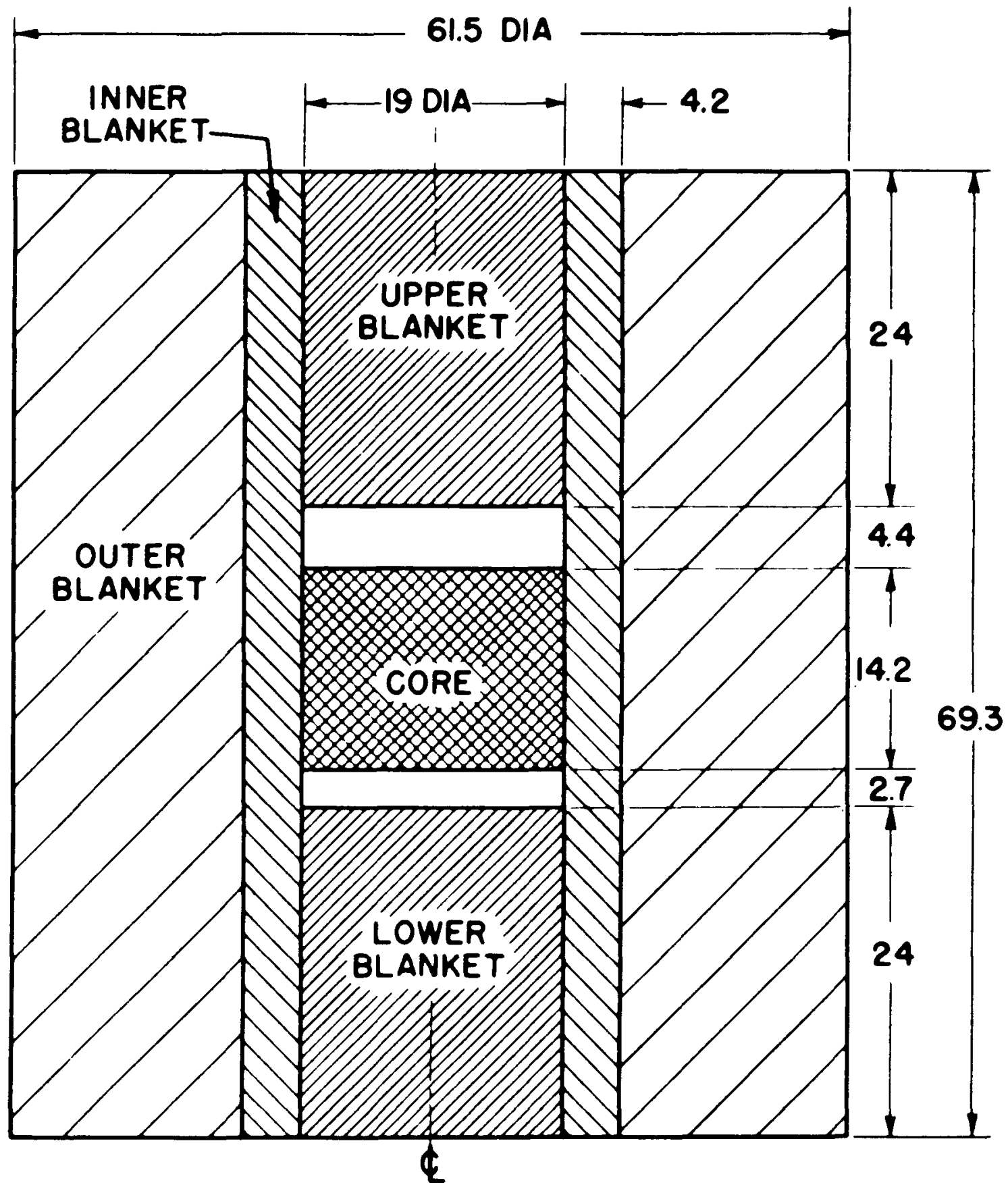

Figure 13.-EBR-II reactor elevation. 


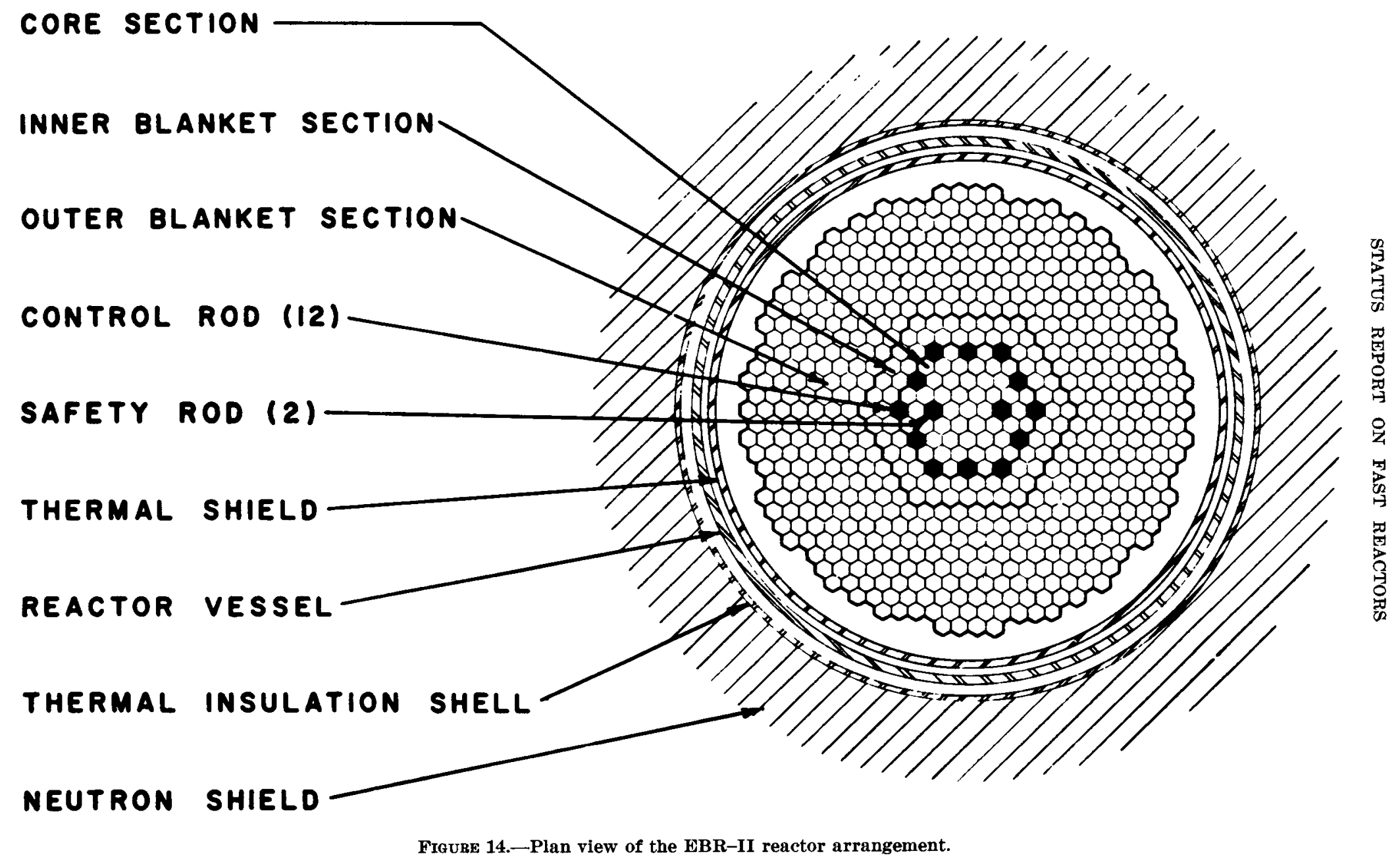




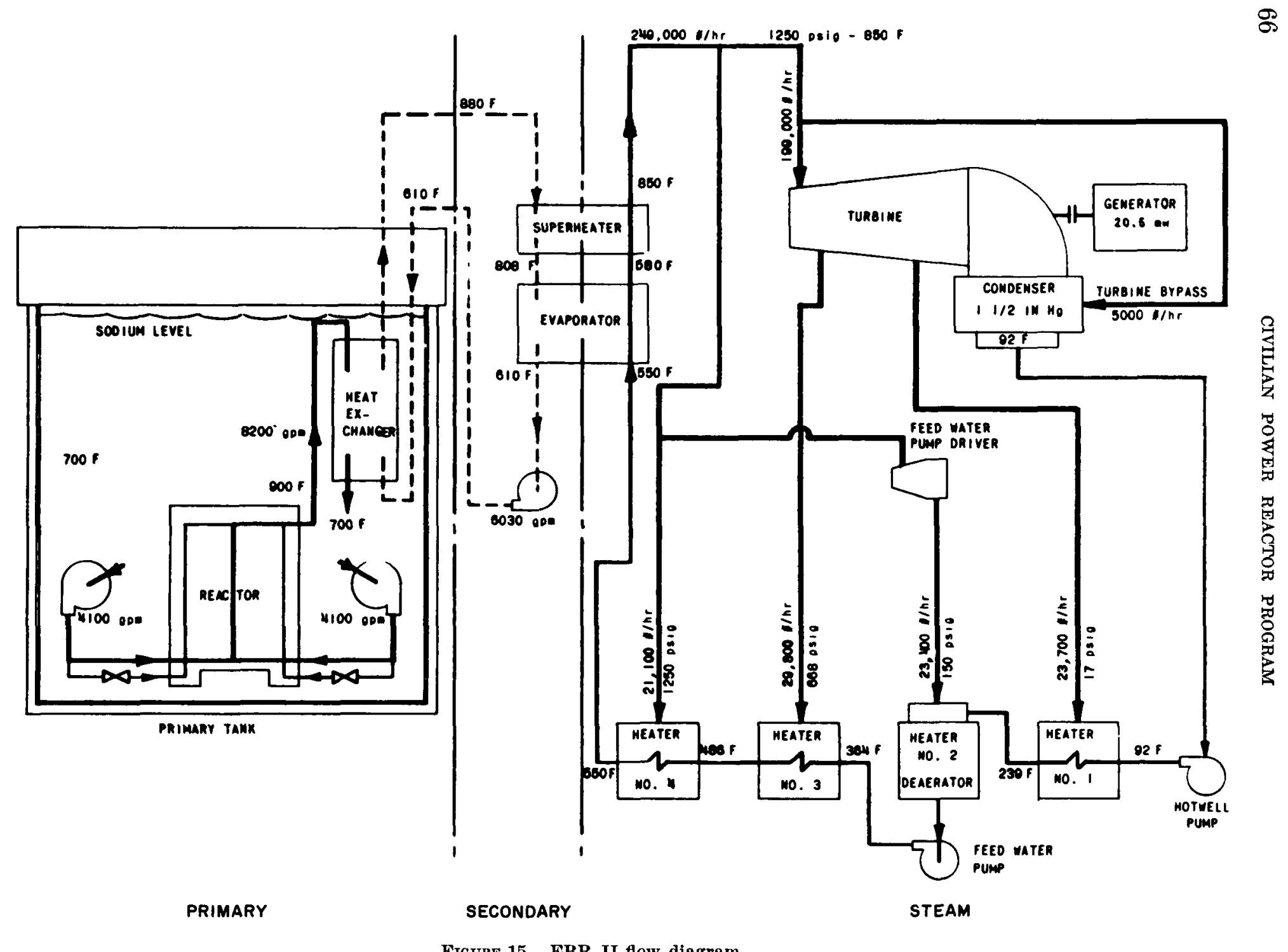

Figure 15.-EBR-II flow diagram. 


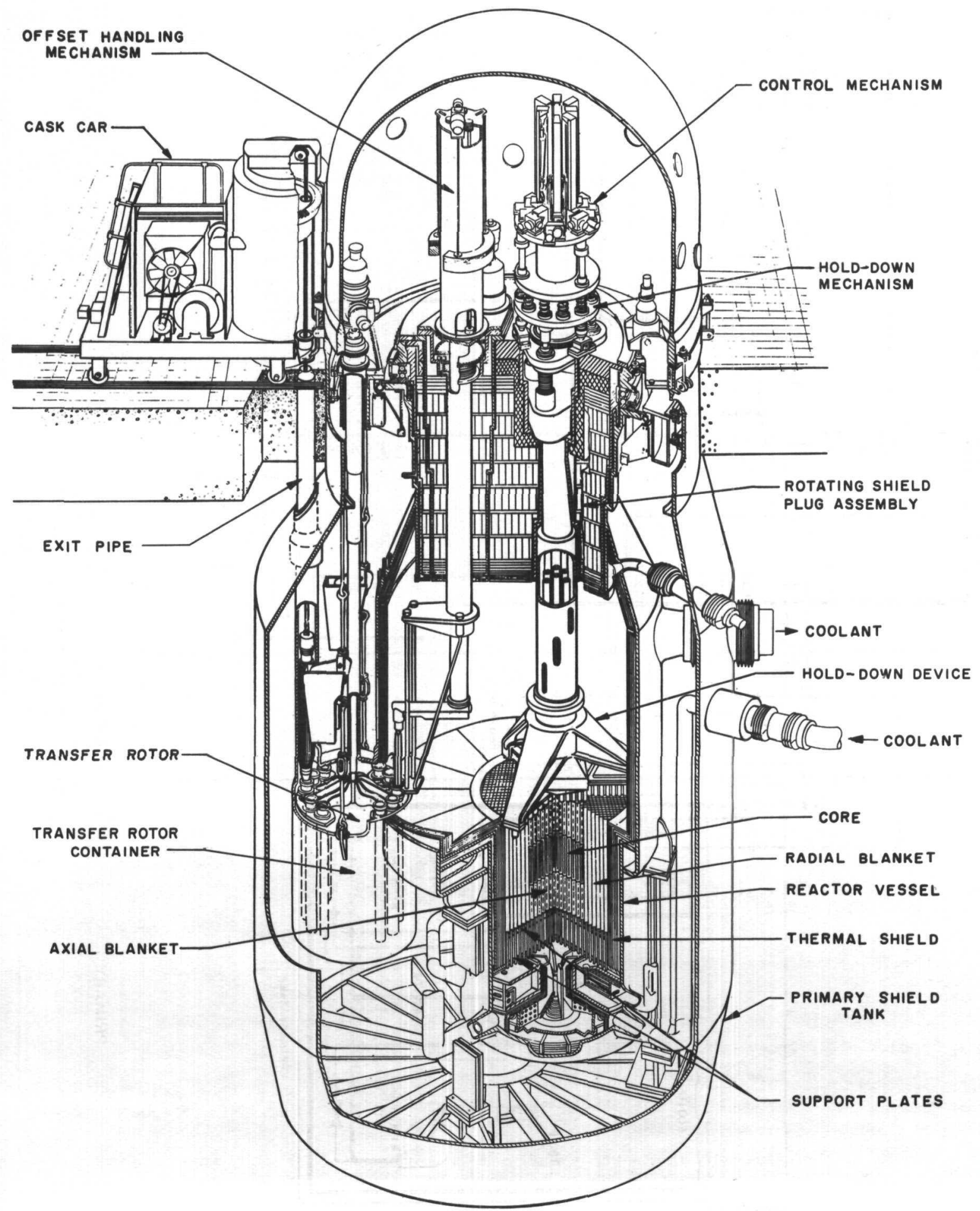

FIGURE 16.-Perspective view of the EFAPP reactor. 


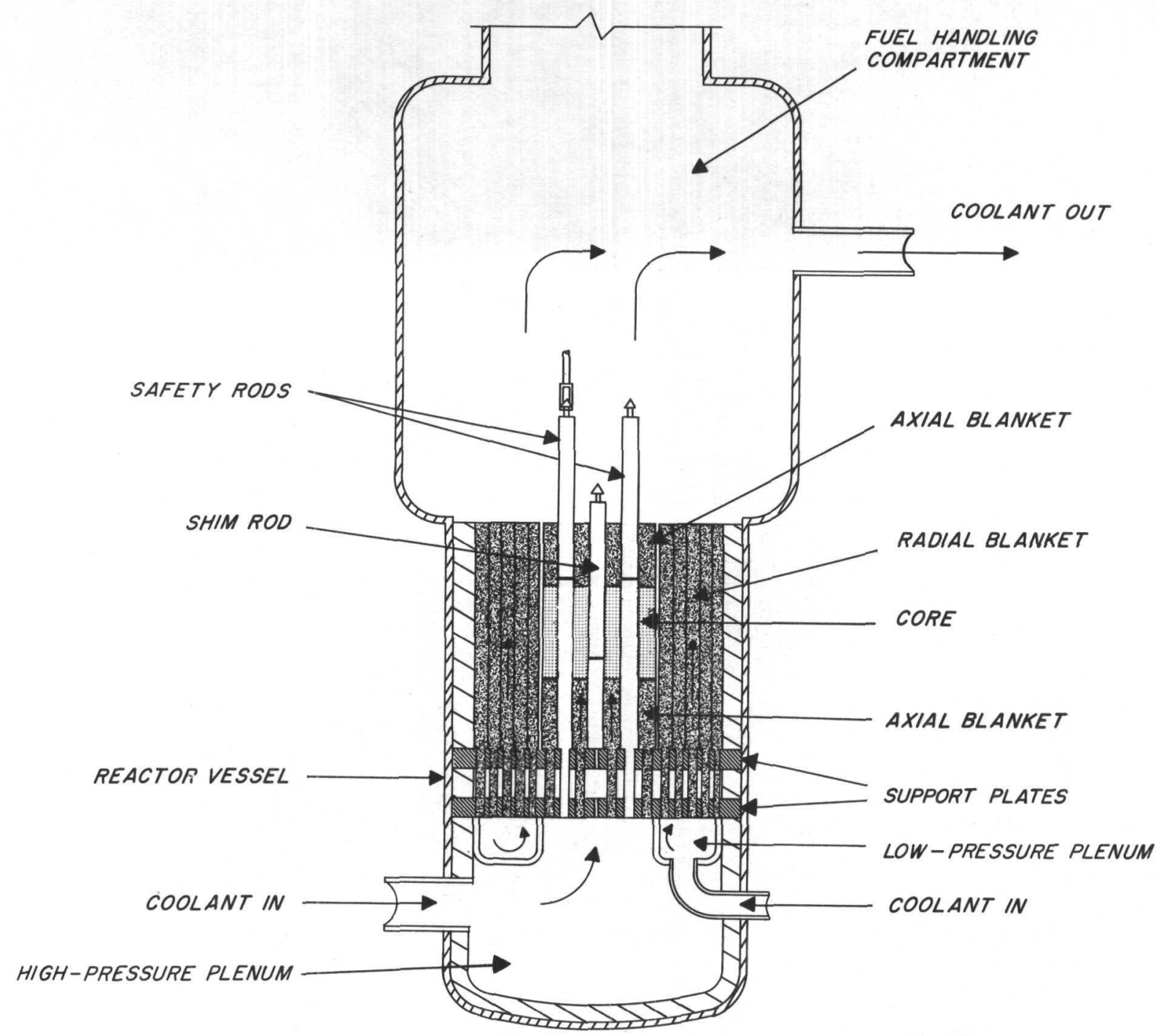

FIGURE 17.-EFAPP reactor arrangement. 


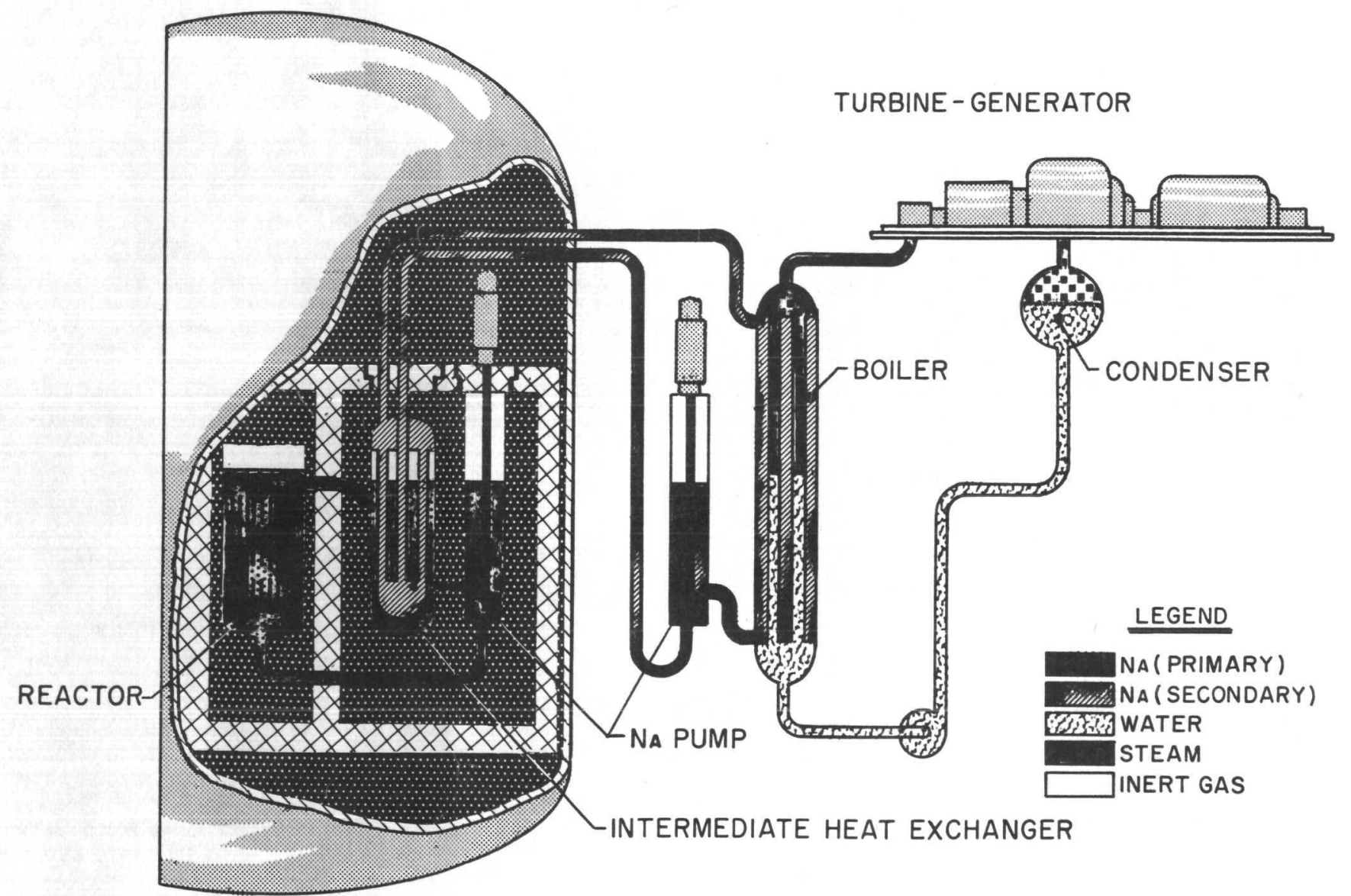

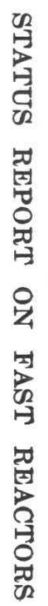

FrguRE 18.-EFAPP plant arrangement. 
I. STEAM GENERATOR HOUSE

2. GASTIGHT BUILDING

3. TRANSFER CASK CAR

4. PRIMARY SODIUM OVERFLOW TANK

5. REACTOR

6. PRIMARY SODIUM PUMP

7. INTERMEDIATE HEAT EXCHANGER

8. SECONDARY SODIUM PUMP

9. STEAM GENERATOR

10. SECONDARY SODIUM DUMP TANK

II. CONTROL ROOM

12. TURBINE - GENERATOR

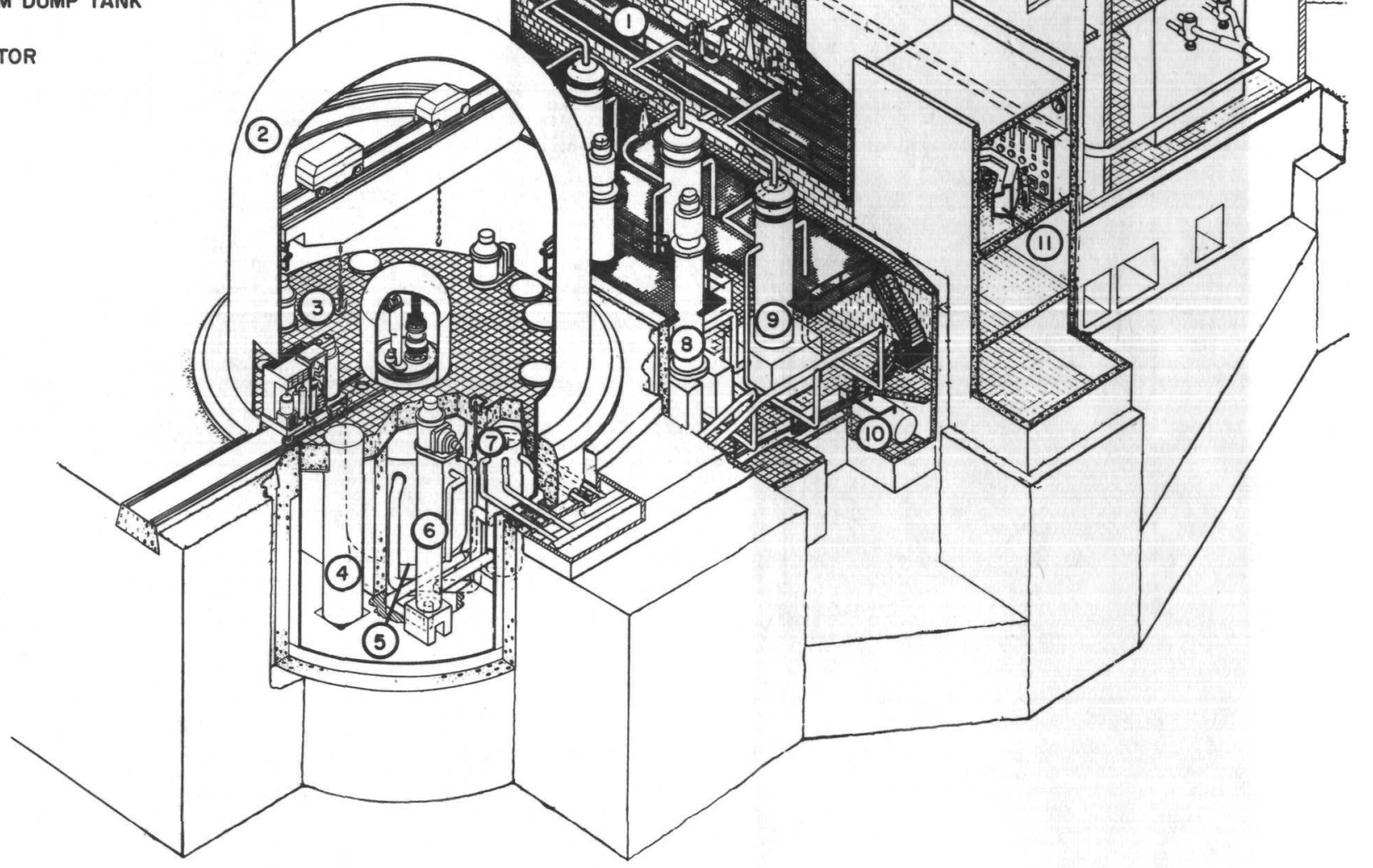




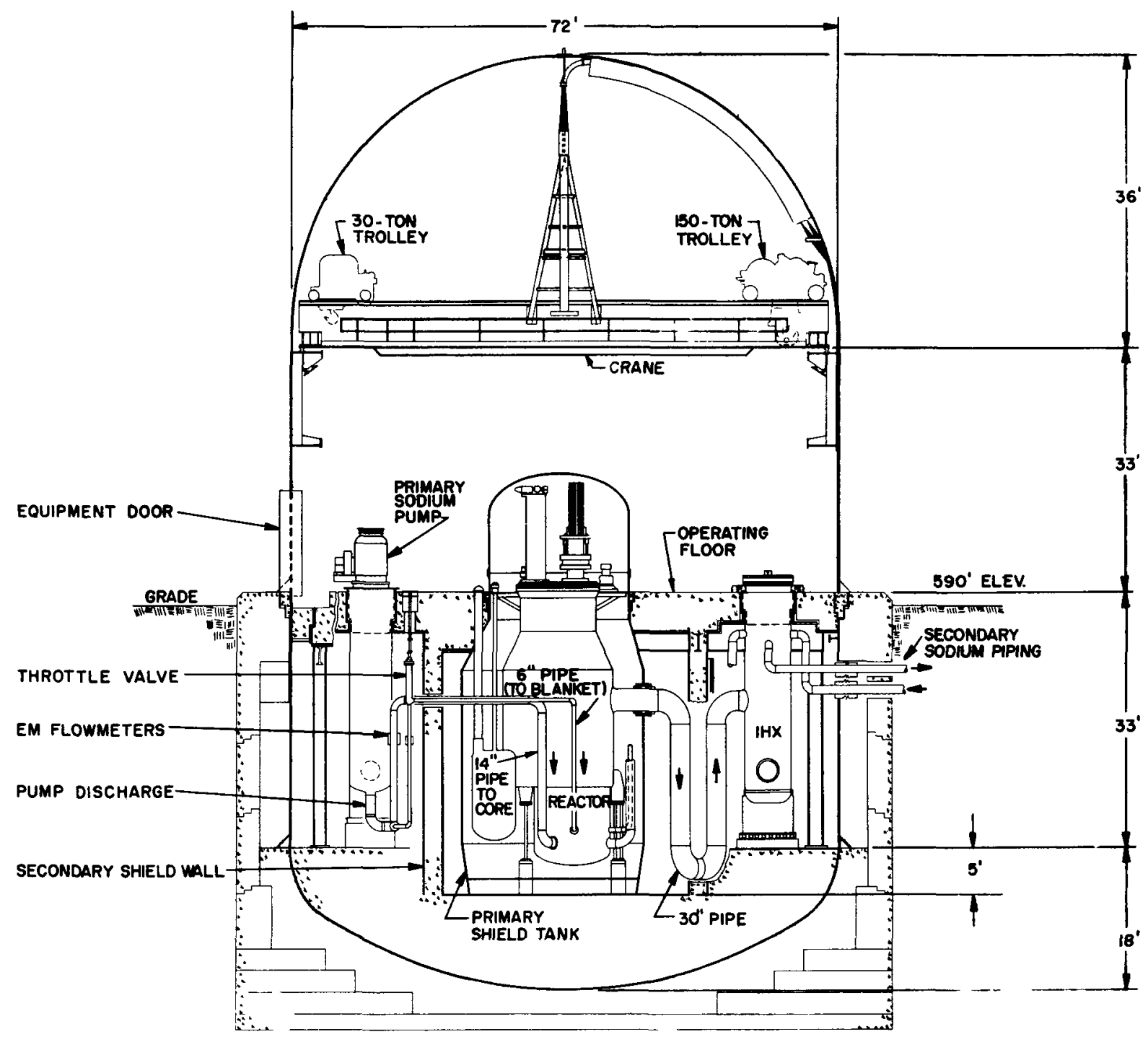

FIgURE 20.-Elevation of reactor plant (EFAPP). 


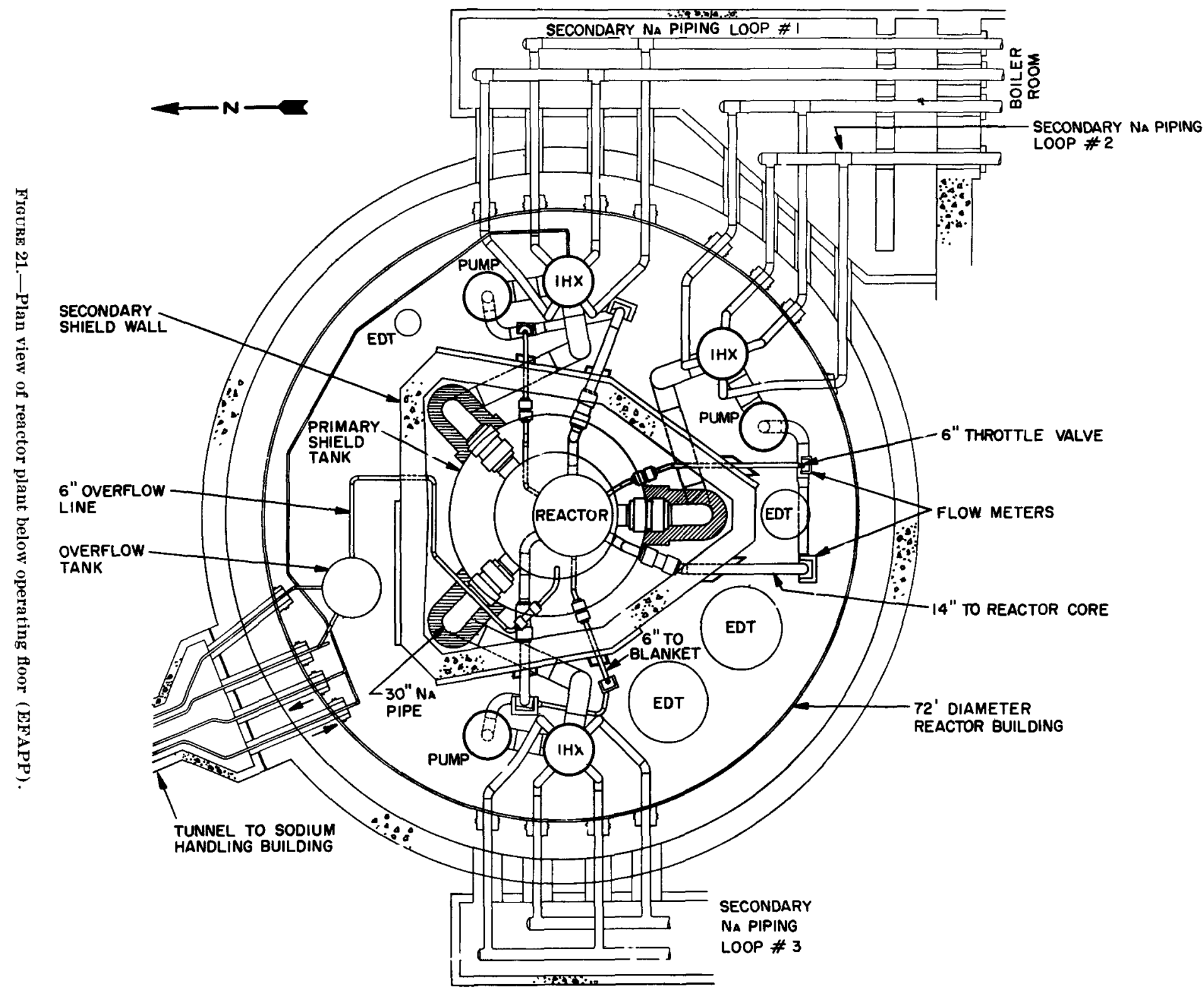




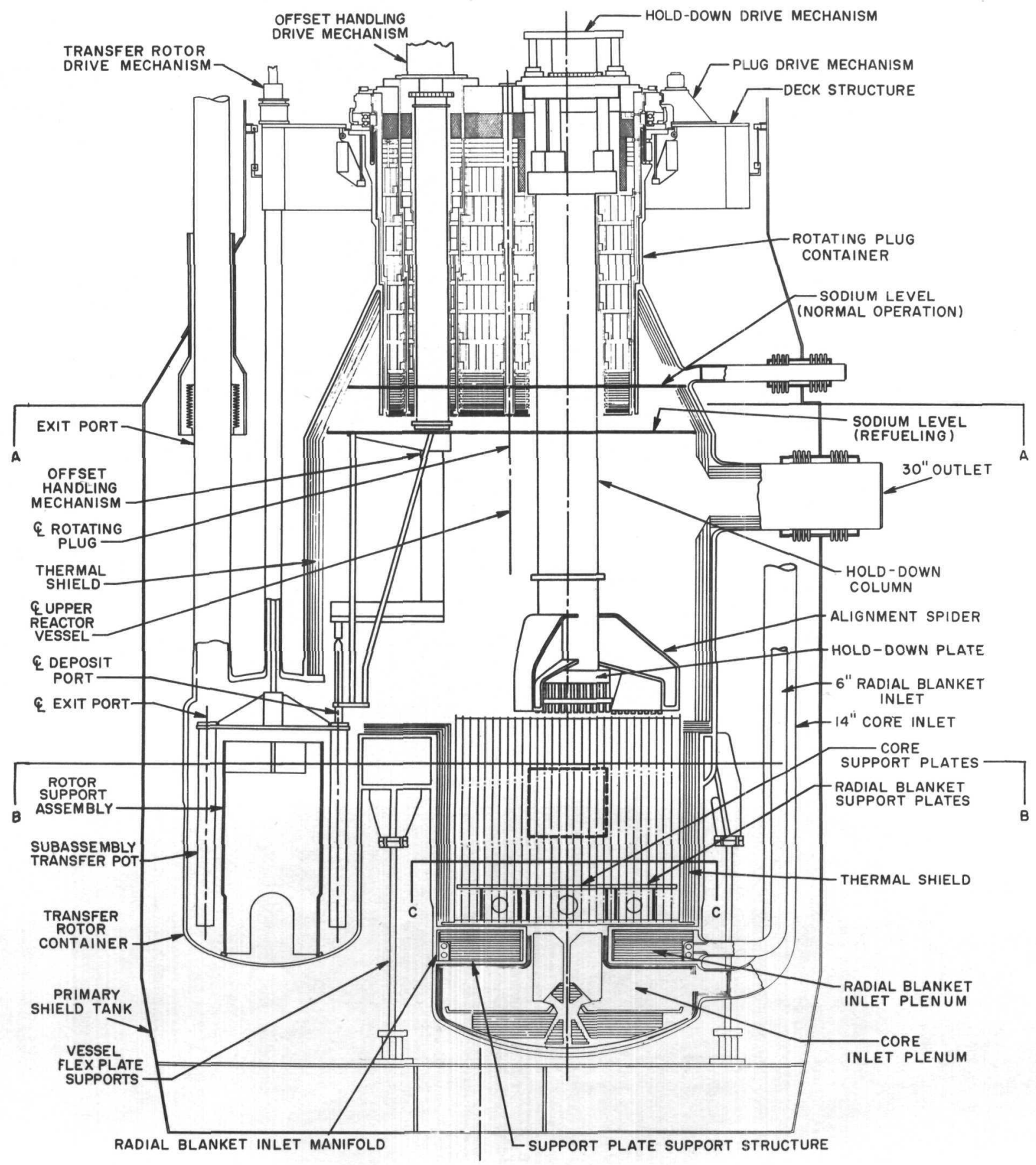

FiguRE 22.-EFAPP reactor vessel (elevation). 


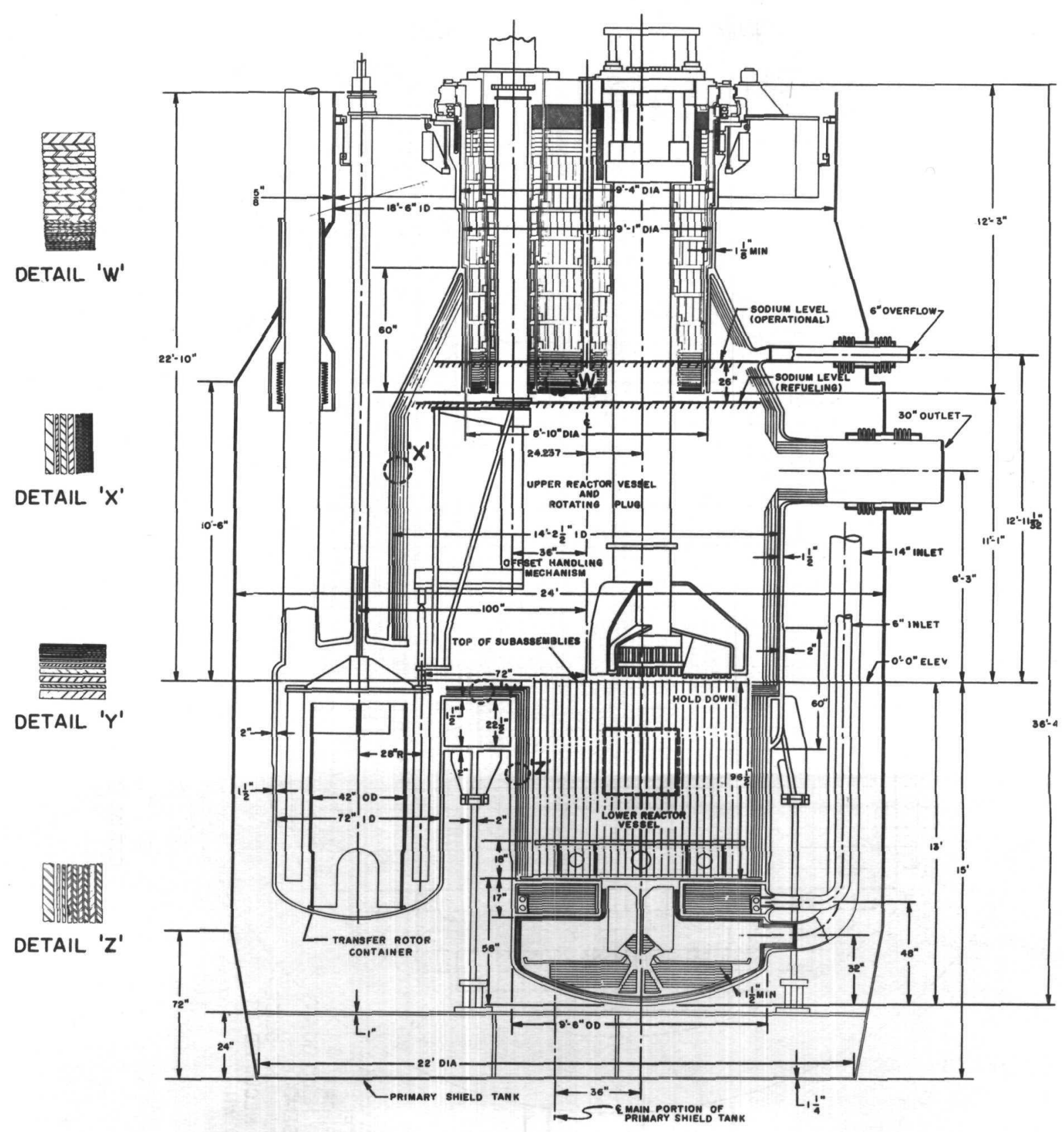

Figure 23.-EFAPP reactor vessel (dimensional). 


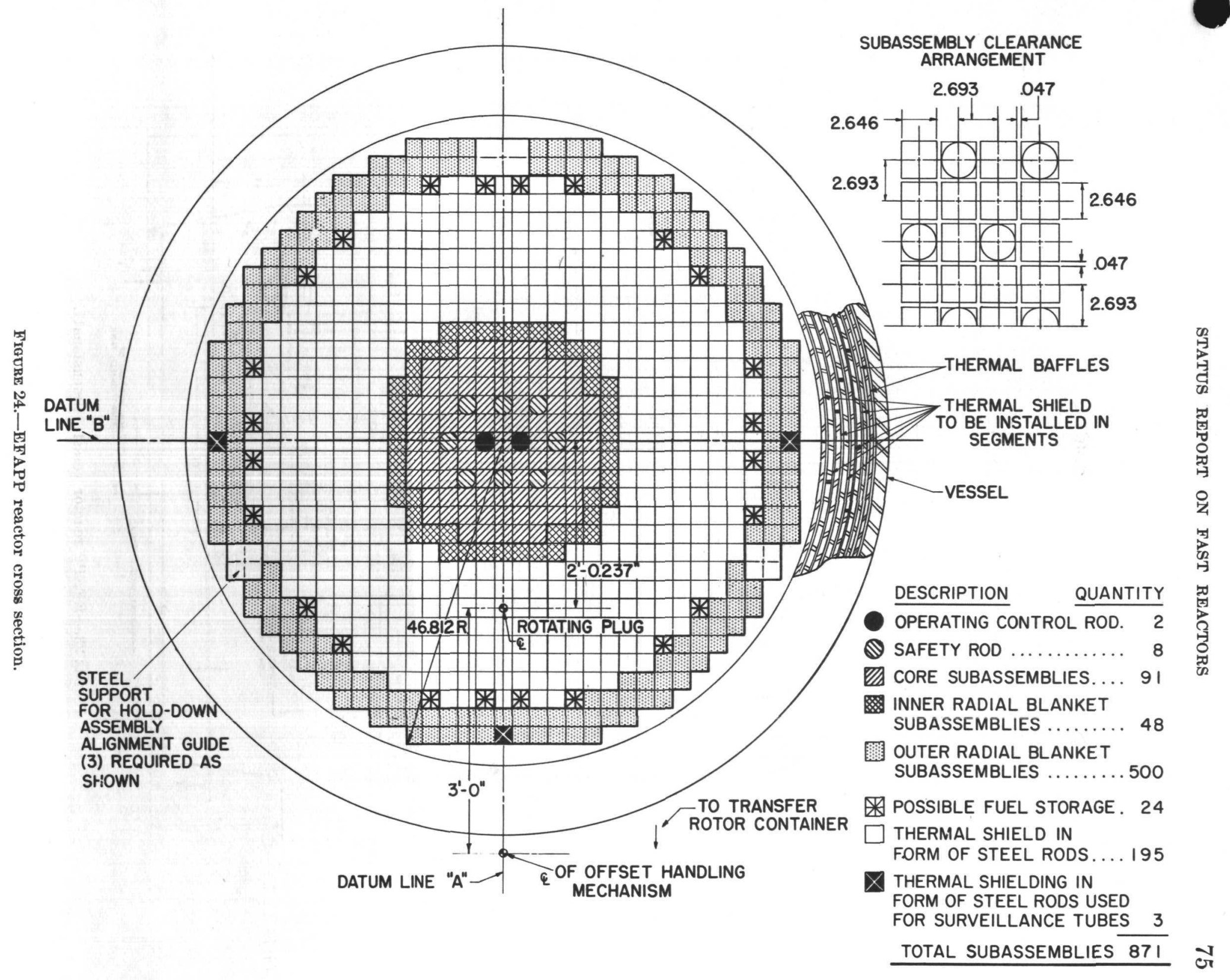




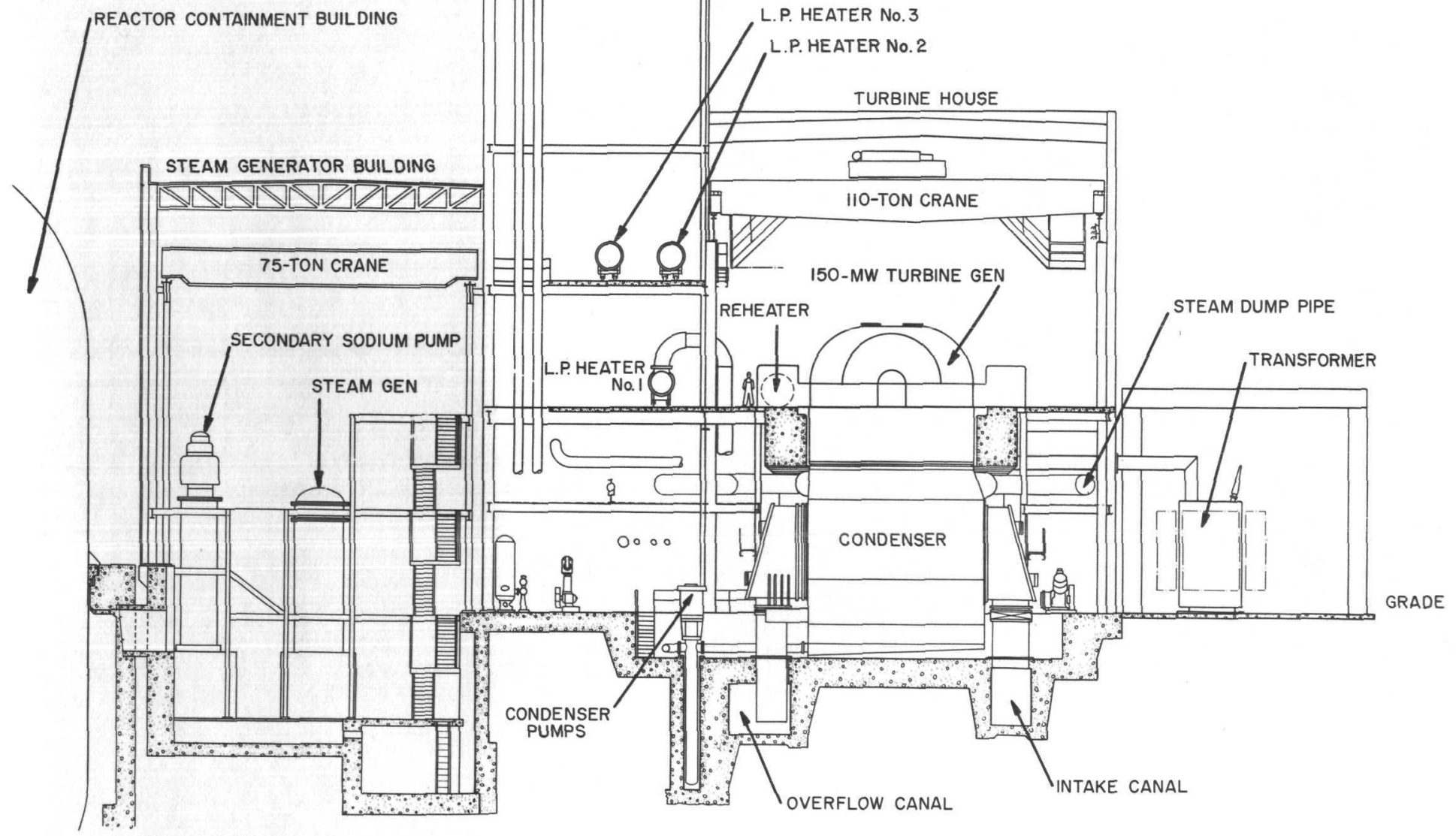




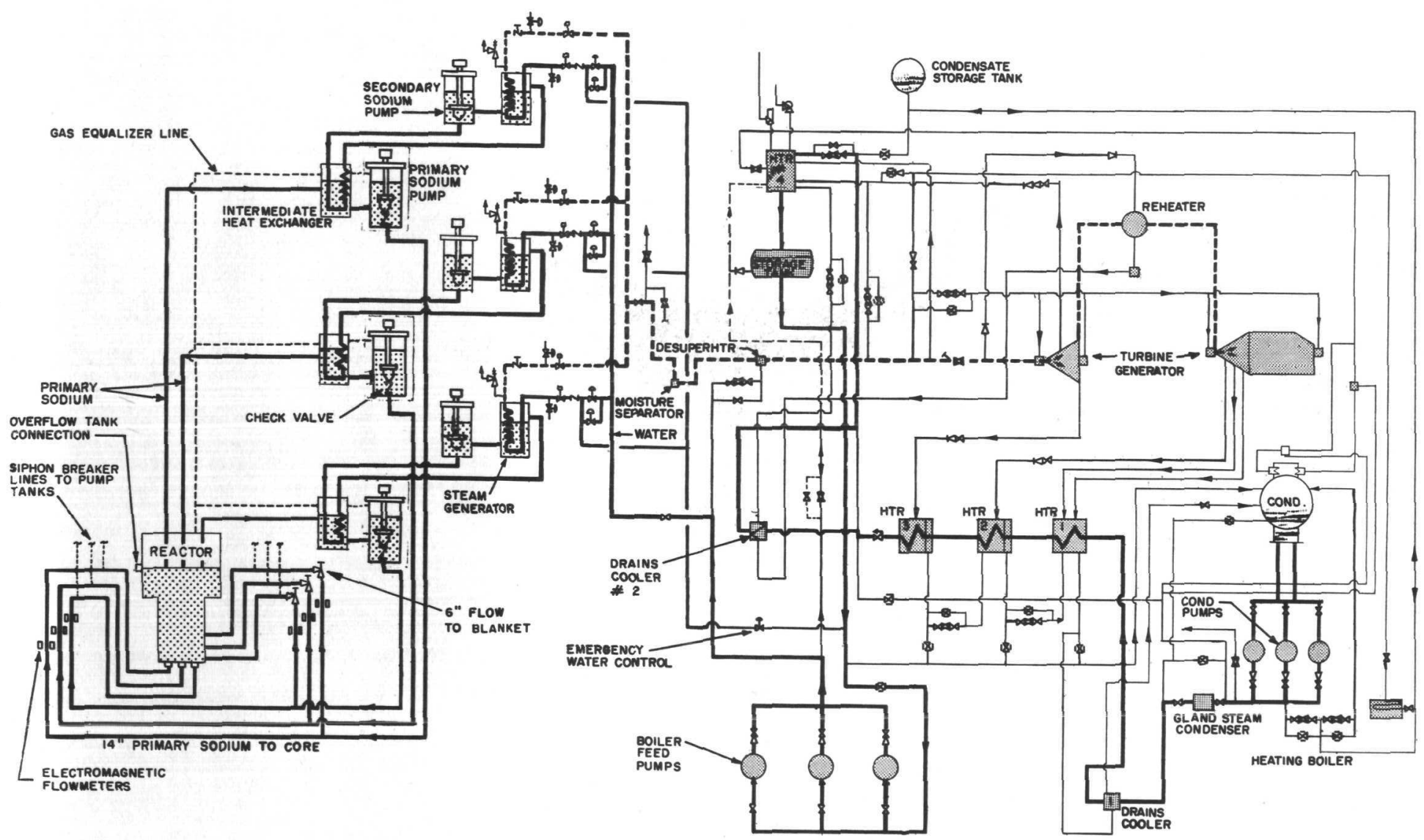

FIGURE 26.-Flow diagram of the nuclear power plant (EFAPP). 

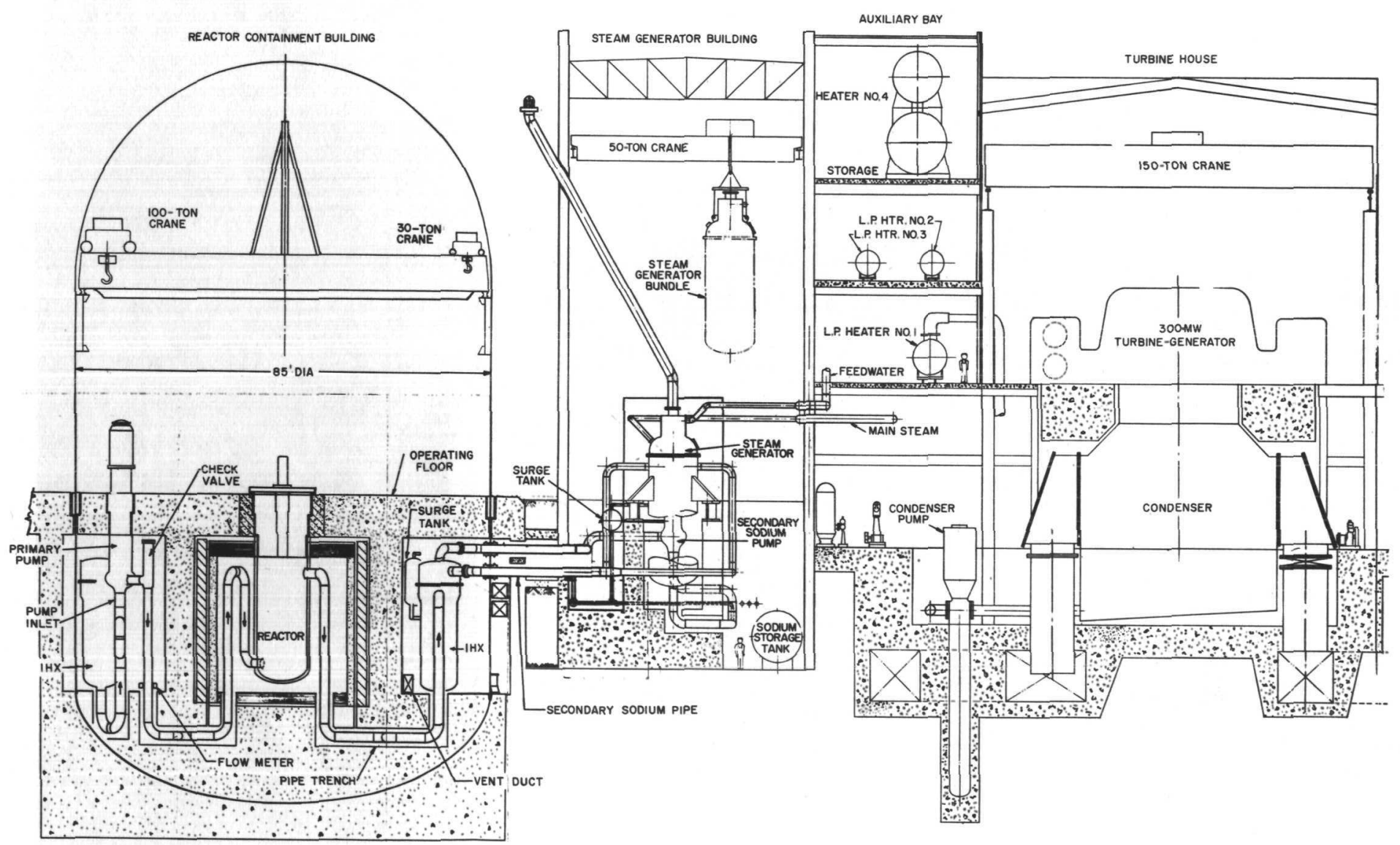



FIgURE 27.-PFFBR plant layout. 


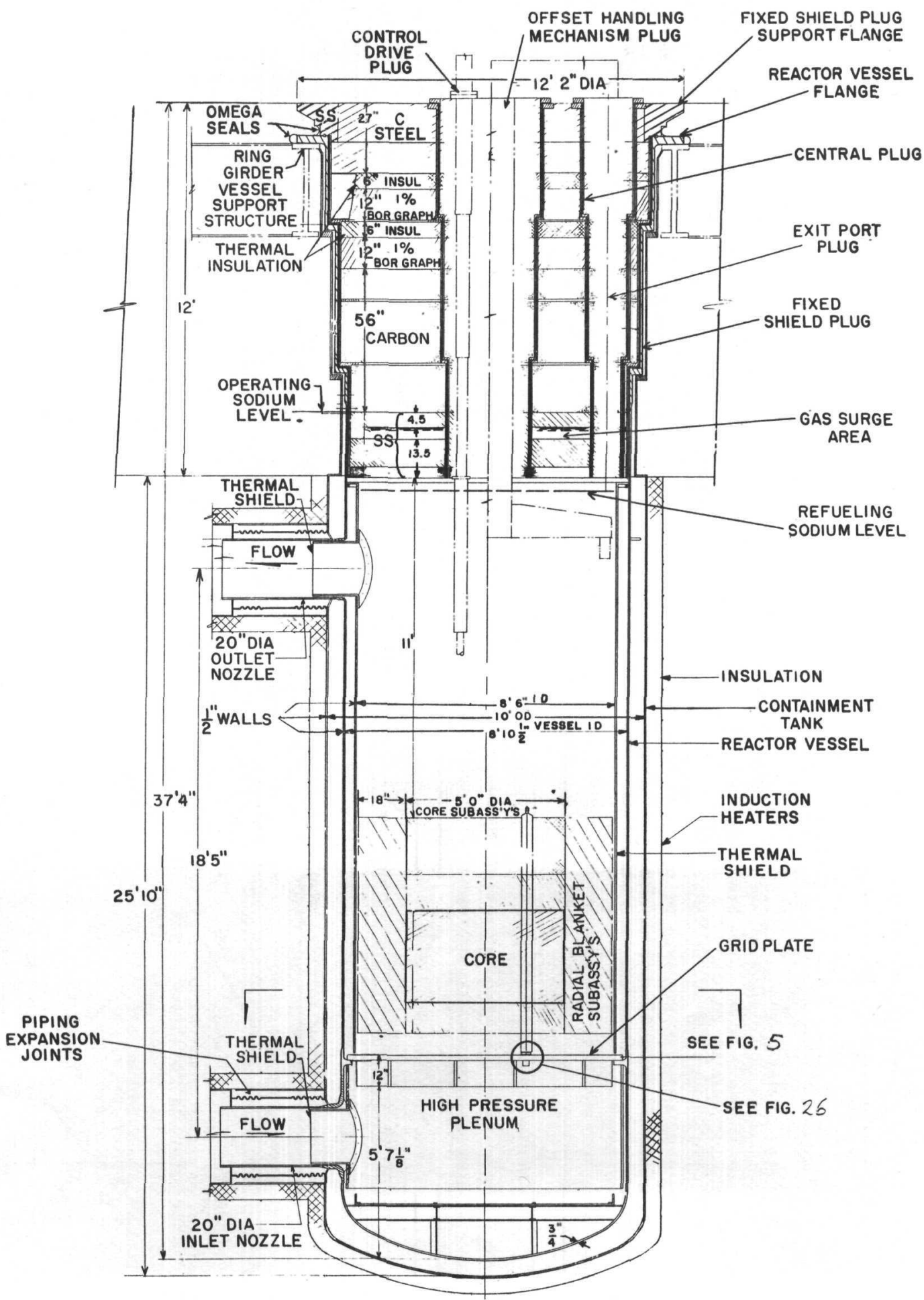

Figure 29.-PFFBR reactor vessel. 


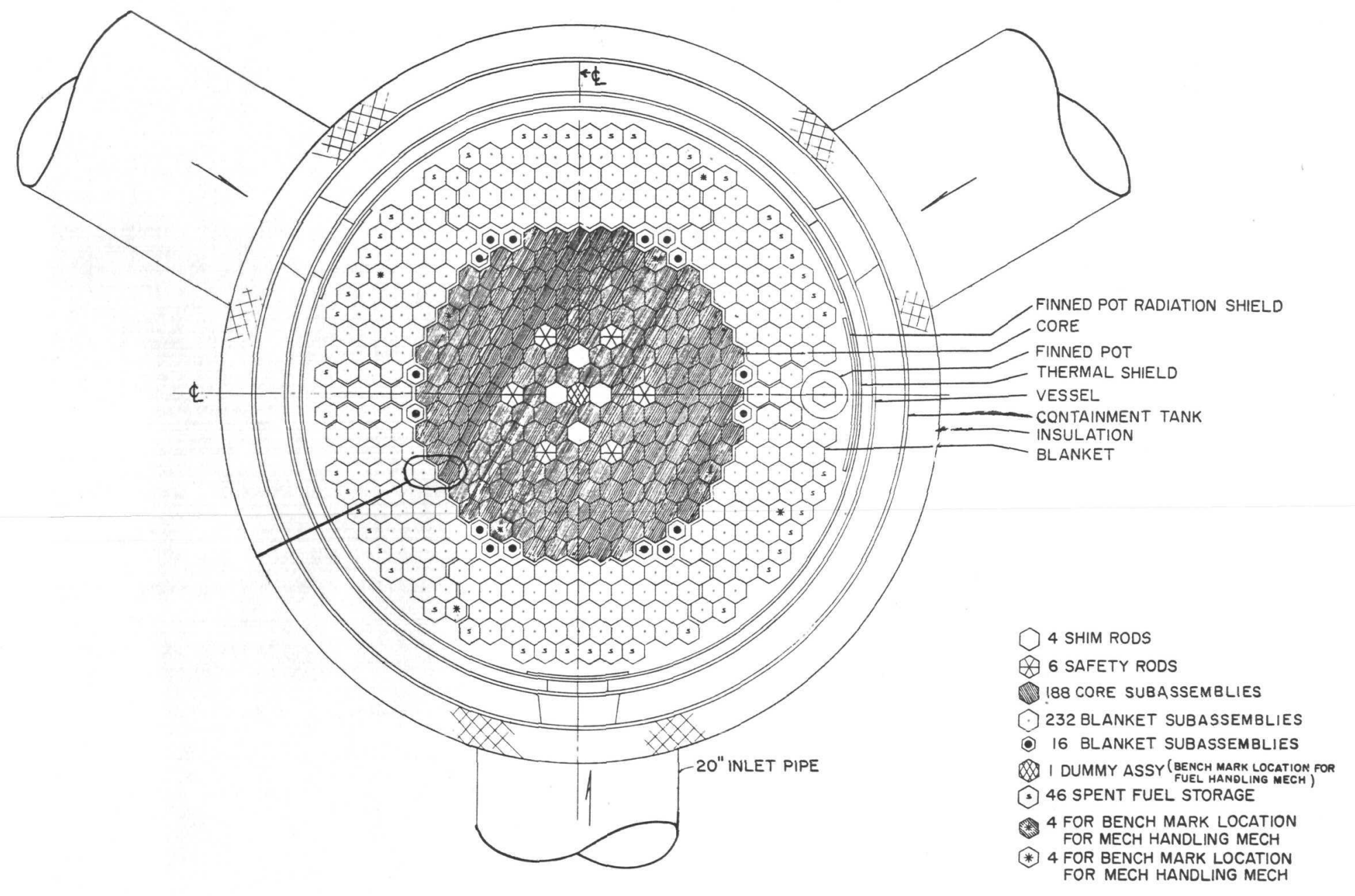

Figure 30.-PFFBR reactor cross section. 


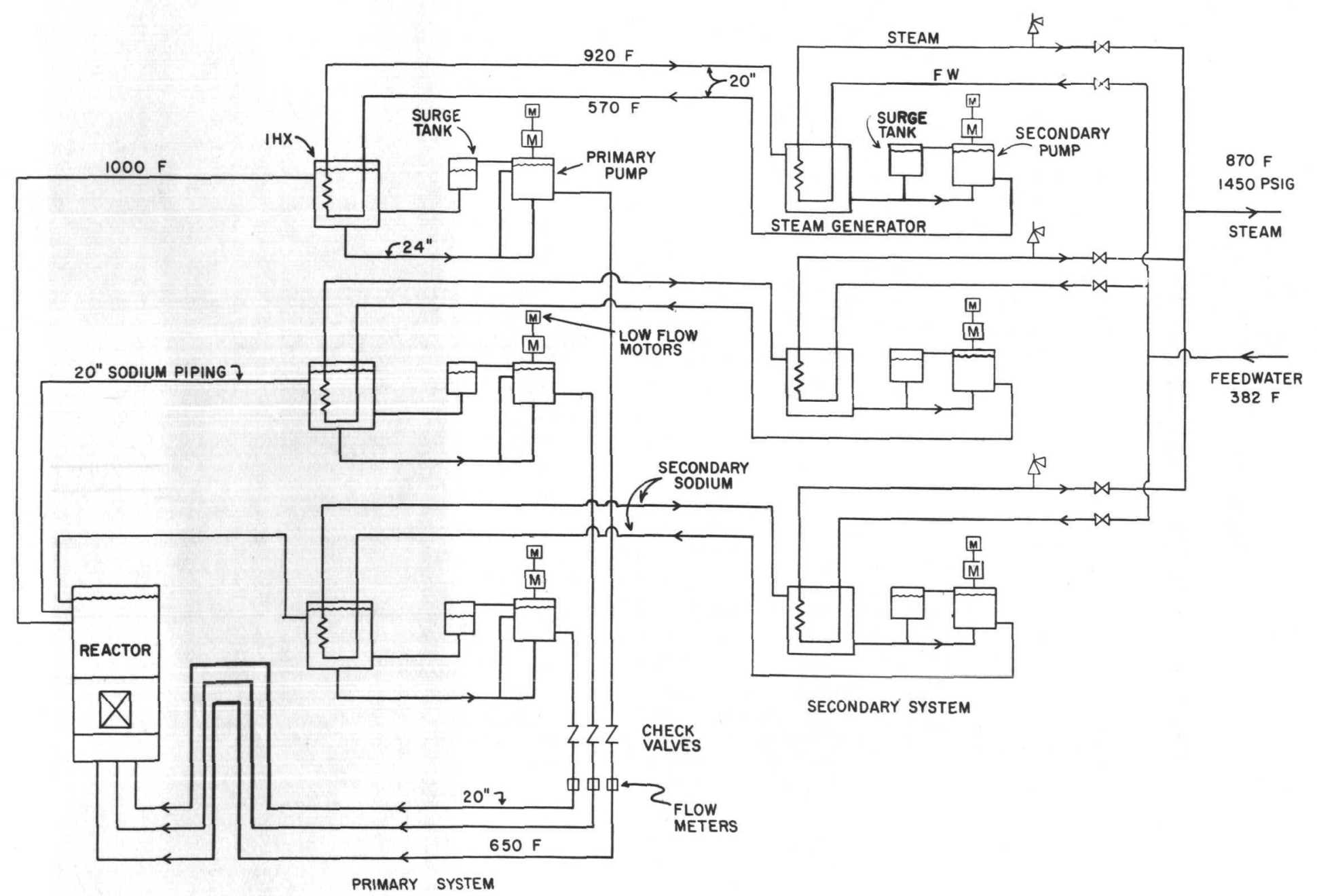

FIGURE 31.-PFFBR flow diagram for primary and secondary sodium systems. 


\section{Appendix E}

\section{BIBLIOGRAPHY AND REFERENCES}

\section{Fast Reactor Physies and Safety}

1. W. J. МсСавтну, Jr., Some Inherent and Design Safety Features of the APDA Fast Breeder Reactor, USAEC Report AECU-3196, Atomic Power Development Associates, Inc., June 1956.

2. A. M. LANE et al., An Estimation of the Doppler Effect in Fast Neutron Reactors, Report AERE T/M-137, Great Britain Atomic Energy Research Establishment, July 1956.

3. R. M. Absalom et al., Studies on Zephyr with a Thorium Envelope, Report AERE R/R-2151, Great Britain Atomic Energy Research Establishment, Jan. 31, 1957.

4. H. Rose and R. M. ABsalom, The Effectiveness of Neutrons as a Function of Their Energy in the Natural Uranium Envelope of Zephyr, Report AERE R/R-2150, Great Britain Atomic Energy Research Establishment, Mar. 4, 1957.

5. J. E. R. Holmes et al., Neutron Distribution in the Air Spaced Core Assembly of Zephyr, Report AERE R/R-1949, Great Britain Atomic Energy Research Establishment, June 1956.

6. H. Rose and R. D. SMITH, Zephyr Perturbation Studies, Report AERE RP/M-48, Great Britain Atomic Energy Research Establishment, Nov. $26,1956$.

7. J. E. R. HoLmes, Flux Heasurements in Zephyr, Report AFRE RP/M-49, Great Britain Atomic Energy Research Establishment.

8. R. Batchelor, The Inelastic Scattering of Neutrons by Uranium, Report AERE NP/R-1629, Great Britain Atomic Energy Research Establishment, Feb. 11, 1955.

9. T. M. FRY and C. A. ReNNiE, Nuclear Design of Fast Reactors, Report AERE NPC-53/4, Great Britain Atomic Energy Research Establishment, Sept. 4, 1953.

10. S. UNTERMYER, Fission Rate Measurements in the Experimental Breeder Reactor (CP-4), USAEC Report ANL-4811, Argonne National Laboratory, Apr. 18, 1952.

11. D. OKRent and L. S. Shepherd, Joint Status Report on Fast Reactor Physics, USAEC Report ANL-5491, Argonne National Laboratory and Great Britain Atomic Energy Research Establishment, October 1955.
12. B. C. Cerutri et al., ZPR-III, Argonne's Fast Critical Facility, Nuclear Sci. and Eng., 1: 126134 (1956).

13. R. O. Brittan, Some Problems in the Safety of Fast Reactors, CSAEC Report ANL-5577, Argonne National Laboratory, May 1956.

14. R. AVERY, Fast Reactor Physics Calculations, USAEC Report ANL-5492(Del.), Argonne National Laboratory, Jan. 17, 1957.

15. F. H. Martens, The Fast Exponential Experiment, USAEC Report ANL-5379, Argonne National Laboratory, November 1955.

16. A. Langsdorf et al., Neutron Scattering Angular Distribution, USAEC Report ANL-5567, Argonne National Iaboratory, June 1956.

17. Argonne National Laboratoky, Fast Reactors, in Reactor Physics Constants, sec. 6, USAEC Report ANL-5800, 1958.

18. M. K. Butler and J. M. Cook, CNIT AC Programs for the Solution of One-Dimensional Multigroup Reactor Equations, CSAEC Report ANL-5437, Argonne National Laboratory, October 1956.

19. J. H. Kittel et al., The EBR-I Meltdown-Physical and Metallurgical Changes in the Core, Nuclear Sci. and Eng., 4: 180-199 (1958).

20. D. OKrent, Fast Reactor Safety Program-A Status Report, paper presented at the meeting of the American Nuclear Society, Gatlinburg, Tenn., June 1959.

21. J. K. Long et al., Kinetic Studies on EBR-I-A Progress Report, paper presented at the meeting of the American Nuclear Society, Gatlinburg, Tenn., June 1959.

22. J. D. GeIEr et al, Engineering Design, Construction, and Early Operational Experience on the TREAT Reactor, paper presented at the meeting of the American Nuclear Society, Gatlinburg, Tenn., June 1959.

23. C. E. Dickerman et al., TREAT In-Pile Experimental Program, paper presented at the meeting of the American Nuclear Society, Gatlinburg, Tenn., June 1959.

24. J. M. Morelle et al., Out-Of-Pile Experiments Related to Fast Reactor Safety, paper presented at the meeting of the American Nuclear Society, Gatlinburg, Tenn., June 1959. 
25. J. M. Cook et al., A Computing Program for Coupled Neutronics-Hydrodynamics Calculations on the IBMI-704, paper presented at the meeting of th American Nuclear Society, Gatlinburg, Tenn., June 1959.

26. V. Z. JANkus, A Parameter Study Using Ax-1, paper presented at the meeting of the American Nuclear Society, Gatlinburg, Tenn., June 1959.

27. H. A. BETHE, Reactor Safety and Oscillator Tests, Report APDA-117, Atomic Power Development Associates, Inc., Oct. 15, 1956.

28. E. C. BraNyaN (editor), Fast Reactor Control and Safety Meeting, Held at Detroit Edison Co. on Nov. 10-11, 1954, USAEC Report APDA105, Atomic Power Development Associates, Inc., Mar. 11, 1957.

29. H. A. Bethe, On the Doppler Effect in Fast Reactors, Report APDA-119, Atomic Power Development Associates. Inc., Mar. 11, 1957.

30. E. L. Alexanderson, The Critical Experiment for the Enrico Fermi Reactor, IISAEC Report AECC-3815, Atomic Power Development Associates, Inc., June 16, 1958.

31. D. J. Hughes and J. A. Harvey, Neutron Cross Sections, USAEC Report BNL-325, Superintendent of Documents, I.S. Government Printing Office, Washington 25, D.C., July 1, 1955.

32. D. J. Hughes and R. B. Schwakts, Neutron Cross Sections, ISAEC Report BNL-325 (supp. 1), Superintendent of Documents, U.S. Government Printing Office, Washington 25, D.C., Jan. 1, 1957.

33. D. J. Hughes and R. S. CARTer, Neutron Cross Sections: Angular Distributions, ISAEC Report BNL-400, Brookhaven National Laboratory, June 1956.

34. M. Tobias and M. C. EdLund, The Influence of the Ifethod of Calculating Resonance Capture on the Fust Leakage in Breeders, USAEC Report CF-53-6-158, Oak Ridge National Laboratory, June 16, 1953.

35. G. C. HaNna and P. R. TLNnicliffe, Fast Fission Factor Experiments: Reactor Core Conference, Jan. 9 to 12, 1956, Report CRRP-623, Atomic Energy of Canada, Ltd., Jan. 4, 1956.

36. V. F. Weisskopf, The Theoretical Prediction of Neutron Cross-Sections of Non-Fissionable Elements for Energies up to $10 \mathrm{Mev}$, in Proceedings of the International Conference on the Peaceful Tres of Atomic Energy, vol. 2, P/830, p. 23, Inited Nations, New York, 1956.

37. D. Szteinsznader et al., Energy Dependence of ${ }^{+233}, \mathbf{L}^{235}, \mathbf{P u}^{239}$ Fast Neutron Cross Sections, in Proceedings of the International Conference on the Penceful Cses of Atomic Eneray, vol. 4, P/355, p. 245. United Nations, New York, 1956.
38. J. E. R. Holmes et al., Experimental Studies on Fast Neutron Reactors at AERE, in Proceedings of the International Conference on the Peaceful T'ses of Atomic Energy, vol. 5, P/404, p. 331, United Nations, New York, 1956.

39. F. C. Beyer et al., The Fast Exponential Experiment, in Proceedings of the International Conference on the Peaceful Uses of Atomic Energy, vol. 5, P/598, p. 342, United Nations, New York, 1956.

40. G. Goertzed, An Estimation of Doppler Effect in Intermediate and Fast Neutron Reactors, in Proccedings of the International Conference on the Peaceful Uses of Atomic Energy, vol. 5, $\mathrm{P} / 613$, p. 472, United Nations, New York, 1956.

41. D. Okrent et al., A Survey of the Theoretical and Experimental Aspects of Fast Reactor Physics, in Proceedings of the International Conference on the Peaceful I'ses of Atomic Energy, vol. 5, P/609, p. 347, United Nations, New York, 1956.

41A. Ibid.

42. R. T. Frost et al., Measurement of Doppler Temperature Coefficient in Intermediate and Fast Assemblies, A/Conf. 15/P/1777, prepared for the Second Cnited Nations International Conference on the Peaceful Uses of Atomic Energy, September 1958.

43. H. O. Monson and T. R. BCMP, Predicted Dynamic Behavior of EBR-II, A/Conf. 15/P/458, prepared for the Second United Nations International Conference on the Peaceful Uses of Atomic Energy, September 1958.

44. G. F. Hansen, Properties of Elementary FastNeutron Critical Assemblies, A/Conf. 15/P/592, prepared for the Second United Nations International Conference on the Peaceful Uses of Atomic Energy, September 1958.

45. J. K. Lovg et al, Fast Neutron Power Reactor studies with $Z P R-I I I$, A/Conf. 15/P/598, prepared for the Second United Nations International Conference on the Peaceful Uses of Atomic Energy, September 1958.

46. W. B. Loewenstein and D. OKRent, The Physics of Fast Power Reactors-A status Report, A/Conf. 15/P/637, prepared for the Second United Nations International Conference on the Peaceful Uses of Atomic Energy, September 1958.

47. A. L. Leipunsky et al., Studies in the Physics of Fast Neutron Reactors, A/Conf. 15/P/2038, prepared for the Second Inited Nations International Conference on the Peaceful Uses of Atomic Energy, September 1958.

48. F. W. ThalgotT et al., Stability Studies on EBR-I, A $/$ Conf. $1.5 / P / 1845$, prepared for the Second 
United Nations International Conference on the Peaceful Eses of Atomic Energy, September 1958.

49. G. A. Freund et al., TREAT, A Pulsed GraphiteModerated Reactor for Kinetic Experiments, A/Conf. 15/P/1848, prepared for the Second United Nations International Conference on the Peaceful Uses of Atomic Energy, September 1958.

50. W. J. MCCarthy, Jr., et al., studies of Nuclear Accidents in Fast Pouer Reactors, A/Conf. $15 / \mathrm{P} / 2165$, prepared for the Second United $\mathrm{Na}-$ tions International Conference on the Peaceful Uses of Atomic Energy, September 1958.

51. W. R. Stratton et al., Analysis of Prompt Excursions in Simple Systems and Idealized Fast Reactors, A/Conf. 15/P/431, prepared for the Second United Nations International Conference on the Peaceful Uses of Atomic Energy, September 1958.

52. R. O. BRITtan, Analysis of EBR-I Core Meltdown, A/Conf. 15/P/2156, prepared for the Second United Nations International Conference on the Peaceful Cses of Atomic Energy, September 1958.

53. B. C. DIven, Radiative Capture of Fast Neutrons, $A /$ Conf. $15 / P / 667$, prepared for the Second United Nations International Conference on the Peaceful Uses of Atomic Energy, September 1958.

54. B. Carlson et al., Solution of the Transport Equation by the $S_{n}$ Method, A/Conf. 15/P/2386, prepared for the Second United Nations International Conference on the Peaceful Uses of Atomic Energy, September 1958.

55. L. Cranberg and J. S. Levin, Inelastic Neutron Scattering of $\mathrm{U}^{238}$, Phys. Rev., 109(6) : 2063 (1958) .

56. H. Rose, Effective Capture Cross-Sections in the Fast Reactor Zephyr, J. Nuclear Energy, 5(1): 4-15 (1957)

57. J. B. SAMPson and D. F. Molino, An $\alpha_{49}$ (E) Curve Consistent with ERR-I Measurements and also with Most Former Measurements, USAEC Report KAPL-1793, Knolls Atomic Power Laboratory, May 16, 1957.

58. R. H. STARK, Preparation of Input Data for TwoSpace-Dimension I ultigroup, USAEC Report KAPL-1068, Knolls Atomic Power Laboratory, Apr. 23, 1957 .

59. E. L. Wachspress, CURE: A Generalized TwoSpace-Dimension Multigroup Coding for the IB II-704, ISAEC Report KAPL-1724, Knolls Atomic Power Laboratory, Apr. 30, 1957.

60. V. A. Walbran, One-Space-Dimensional Multigroup for the IBM-650. Part II, Machine
Program, USAEC Report KAPL-1531, Knolls Atomic Power Laboratory, Apr. 10, 1956.

61. T. F. Wimet, Time Behavior of Godiva Through Prompt Critical, LSAEC Report LA-2029, Los Alamos Scientific Laboratory, April 1956.

62. H. C. Paxton et al., USAEC Report LA-1671, Los Alamos Scientific Laboratory, May 1954, classified.

63. J. J. Neuer et al., USAEC Report LA-2085, Los Alamos Scientific Laboratory, October 1956, classified.

64. G. A. JARvis et al., Plutonium-Metal Critical Assemblies, USAEC Report LA-2044, Los Alamos Scientific Laboratory, May 1956, classified.

65. V. Josephson et al, Oralloy Shape Factor Measurements, USAEC Report LA-1155(Del.), Los Alamos Scientific Laboratory, Aug. 8, 1950.

66. H. C. Paxton and G. A. Graves, Critical Masses of Fissionable Metals as Basic Nuclear Safety Data, USAEC Report LA-1958(Del.), Los Alamos Scientific Laboratory, April 1956.

67. J. R. Beyster et al., Predictions of Fast Neutron Scattering Data with a Diffuse Surface Potential Well, USAEC Report LA-2099, Los Alamos Scientific Laboratory, December 1956.

68. H. A. BETHE et al., Inelastic Cross-Sections and $\bar{\nu}$ for Some Fissionable Isotopes, USAEC Report LA-1939, Los Alamos Scientific Laboratory, Angust 1955, classified.

69. G. R. Keepin et al., Delayed Neutrons from Fissionable Isotopes of Uranium, Plutonium, and Thorium, Phys. Rev', 107: 1044-1049 (1957).

70. G. A. Linenberger et al., Neutron Detector Traverses in the Topsy and Godiva Critical Assemblies, USAEC Report LA-1653, Los Alamos Scientific Laboratory, June 1953.

71. J. J. Neuer et al., Preliminary Survey of Uranium Ifetal Exponential Columns, USAEC Report LA-2023, Los Alamos Scientific Laboratory, January 1956.

72. B. G. CarLson, Solution of the Transport Equation by $\mathbb{S}_{n}$ Approximations, USAEC Report LA-1891, Los Alamos Scientific Laboratory, February 1955.

73. C. C. OLd, Fast Reactor Poisoning by Fission Products, USAEC Report LWS-24612, California Research and Development Co., Oct. 24, 1952.

74. C. H. Robrins, Neutron Absorption and Radioartivity of Commercial sodium and Lead $E x$ posed to a Ncutron Flux, USAEC Report NAASR-Memo-100, Atomics International, Sept. 26, 1951.

75. C. KLAHR, Energy Release in High Hazard Accidents, Report NDA-14-149, Nuclear Development Corp. of America. 
76. L. Davidson and C. KLAHR, Spherical and Cytindrical Adjoint Calculations for the APDA Fast Breeder Reactor, Report NDA-14-153, Nuclear Development Corp. of America, Nov. 14, 1956.

77. P. S. Mittelman, Neutron Penetration Through the Side shield of the APDA Reactor, Report NDA-14-155, Nuclear Development Corp. of America.

78. W. H. JENs, Summary of APDA Fast Reactor Safety studies, Report NDA-27-16, Nuclear Development Corp. of America, October 1956.

79. H. Frshbach et al., An Estimation of Doppler Effect in Fast Neutron Reactors, Nuclear Sci. and Eng., 1: 4-20 (1956).

80. H. YamaUCHI, Preliminary Calculations for the APIDA shield Design, Report NDA-14-72, Nuclear Development Corp. of America, May 9, 1955.

81. R. A. DAANe, Fast Reactor Accident Scaling Laws, Report NDA-14-84, Nuclear Development Corp. of America, May 18, 1955.

82. R. DAane et al, Progress Report on the Study of Low Probability, High Hazard Fast Reactor Accidents, Report NDA-14-107, Nuclear Development Corp. of America, Nov. 11, 1955.

83. J. DeFuLICE, Reactivity Temperature Coefficients in the APDA Reactor, Report NDA-14-113, Nuclear Development Corp. of America.

84. H. Yamauchi and J. DeFerice, Doppler Temperature Coefficients of Reactivity in Fast Reactors, Report NDA-14-82, Nuclear Development Corp. of America.

85. R. A. DaAne, Fast Reactor Safety Studies, Report NDA-14-155 (Rept. No. 2), Nuclear Development Corp. of America.

86. H. G. Elrod, Jr., The Distribution of Melting in a Slow Meltdown Accident, Report NDA-14-170, Nuclear Development Corp. of America, May 1, 1957.

87. J. H. RAY and A. D. KRUMbeIN, Calculated Criticality of the Enrico Fermi Reactor During a Hypothetical Heltdown Accident, Report NDA14-182, Nuclear Development Corp. of America, July 1, 1957.

88. H. G. Elrod, Jr., Freezing and Remelting of Radioactive Material on Cold, Vertical Pins, Report NDA-14-181. Nuclear Development Corp. of America, July 1, 1957.

89. G. Goertzel and C. KLAhr. Interpretation of an Experiment To Measure Doppler Effect, Report NDA-14-127, Nuclear Development Corp. of America, June 29, 1956.

90. J. H. RAY, Extension to 10 Groups of $A P D A$ Multigroup Cross Sections for UNIVAC, RE 6 , 7, and 8 Codes, Report NDA-14-135, Nuclear Development Corp. of America, June 15, 1956 (superseded by USAEC Report ANL-5800).
91. J. H. RAY, Comparison of One-and Two-Dimensional Multigroup Calculations for the APDA Fast Breeder Reactor, Report NDA-14-163, Nuclear Development Corp. of America, Apr. 1, 1957.

92. C. KLAHR, Danger Coefficients for the Enrico Fermi Fast Breeder Reactor, Report NDA-014 167, Nuclear Development Corp. of America, Sept. 3, 1957.

93. Nuclear Development Corp. of America, Formulations Used in Connection with the Numerical Solution of the Diffusion Equation in Cylindrical Geometry, Report NDA-2563-13.

94. Nuclear Development Corp. of America, Comparison of Two-Dimensional Calculation Results for the 91-and 139-Subassembly Cores of the Enrico Fermi Reactor, Report NDA2563-8.

95. R. Schulten, Zur Theorie der Reaktoren mit schneller Neutronen (The Theory of Reactors with Fast Neutrons). Report No. 1 of the Reactor Group of the Max-Planck-Institute of Physics, Goetingen, Germany.

96. P. E. Cavanagh, Fast Neutron Capture CrossSection of $\mathrm{Nb}:$ A statement of the Problem, Report NRDC- 54 , Great Britain Atomic Energy Research Establishment, Oct. 26, 1954.

97. R. E. Peterson, Controlled Bowing of Fuel Subassemblies, paper presented at the Fourth $\mathrm{Nu}$ clear Engineering and Science Conference held in Chicago, Ill., Mar. 17-21, 1958.

98. C. EgGLER et al., Measurement of Neutron Spectra of the Experimental Breeder Reactor, Nuclear Sci. and Eng., 1: 391-408 (October 1956).

99. W. Primak, Fast Neutron Damaging in Nuclear Reactors III. The Radiation Damage Dosage, Nuclear Sci. and Eng., 2: 320-333 (May 1957).

100. R. C. Allen, The Interaction of 0.15- to 1.0-Mev Neutrons with $\mathrm{U}^{238}, \mathrm{U}^{235}$, and $\mathrm{Pu}^{289}$, Nuclear Sci. and Eng., 2: 787 (May 1957).

101. D. Meneghetri et al., Ten-group Calculated Equilibrium Neutron Spectrum and Diffusion Length in Natural Uranium, Nuclear Sci. and Eng., 3: 151 (1958).

102. P. Kafalas et al., Determination of the Ratio of Capture to Fission Cross Sections in EBR-I, Nuclear Sci. and Eng., 2: 657 (May 1957).

103. J. D. Orndorff, Prompt Neutron Periods of Metal Critical Assemblies, Nuclear Sci. and Eng., 2: 450 (May 1957).

104. G. S. Brunson et al, Measuring the Prompt Period of a Reactor, Nucleonics, 15(11): 132 (1957).

105. P. R. KAsteN, Summary of Some Nuclear Data, USAEC Report ORNL-2142, Oak Ridge National Laboratory, Aug. 21, 1956. 
106. B. Davisos, Neutron Transport Theory, Clarendon Press, Oxford, England, 1957.

107. William Primak, Fast Neutron Damaging in Nuclear Reactors; Its Kineties and the Carbon Atom Displacement Rate, Phys. Rev., 103(6): 1681-1692 (1956).

108. B. C. Diven, Fission Cross Section of $\mathbf{U}^{235}$ for Fast Neutrons, $P h_{y / s .} R e v .105(4)$ : 1350-1353 (1957).

109. R. F. Carter and J. R. Beyster, Inelastic Collision Cross Sections for Fission Spectrum Neutrons, Phys. Rev., 90: 389 (1953).

110. L. Cranberg and J. Levis, Inelastic Neutron Scattering by $\mathrm{U}^{238}$, Phys. Rev., 109: 2063 (1958).

111. B. C. Diven et al., Multiplicities of Fast Neutrons, Phys. Rev., 101: 1012 (1956).

112. R. B. Leachman, Emission of Prompt Neutrons from Fission, Phys. Rev., 101: 1005 (1956).

113. J. E. Gindern et al., Neptunium Isotopes, Phys. Rev., 109: 1263 (1958).

114. A. M. LANE and L. E. LYNN, Fast Neutron Capture Below $1 \mathrm{Mev}$ : The Cross Sections for $\mathbf{C}^{235}$ and $\mathrm{Th}^{239}$, Proc. Phys. Soc. (London), A70:557 (1957).

115. P. M. ExdT and C. M. BraAMs, Energy Levels of Light Nuclei, Revs. Modern Phys., 29: 683 (1957).

116. J. R. DieTrich, EBR Oscillations, ISAEC Report TID-5351, Argonne National Laboratory, Mar. $5,1957$.

117. W. J. McCarthy. Jr., and F. C. McMath, Safeguard Features of a Fast-Breeder-Reactor Power Plant, Trans. Am. Soc. Mech. Engrs., 79: 41-46 (1957).

118. F. A. Kloverstrom, spherical and Cylindrical Plutonium Critical IIasses, CSAEC Report UCRL -4957 , University of California Radiation Laboratory, September 1957.

119. G. G. BILodEAU et al., $P D Q-A n I B . I-\gamma 04$ Code To Solve the Tu-dimensional Few-group Neutrondiffusion Equations, USAEC Report WAPDTM-70, Westinghouse Electric Corp., August 1957.

\section{Reactor Containment}

1. J. C. Heap, Equilibrium P-V-T Relations for Expanding Liquid-Tapor Systems in a Containment shell, USAEC Report ANL-5828, Argonne National Laboratory, November 1958.

2. D. R. Ingtis and G. R. RINGo, Underground Construction of Pouer Reactors, USAEC Report ANL-5652, Argonne National Laboratory, January 1957 .

3. R. O. BRITtan, A Reactor Containment Program for the Atomic Energy Commission, USAEC Report ANI-5851, Argonne National Laboratory, April 1958 (superseded by ANI-5948).
4. J. C. Hfap, Cost Estimates for Reactor Containment, Technical Memorandum No. 13, Argonne National Laboratory.

5. R. O. Brittan, Reactor Containment (including a Technical Progress Review), USAEC Report ANL-5948, Argonne National Laboratory, May 1959.

6. L. J. КосH et al., Experimental Breeder Reactor II (EBR $\rightarrow I I)$; Hazard Summary Report, USAEC Report ANL 5719, Argonne National Laboratory, May 1957.

7. Report APDA-114. (Superseded by H. J. Gomberg et al., Report on the Possible Effects on the Surrounding Population of an Assumed Release of Fission Products into the Atmosphere from a 300-Megawatt Nuclear Reactor Located at Lagoona Beach, wich., Report APDA-120, University of Michigan, July 1957.)

8. Atomic Power Development Associates, INc., Enrico Fermi Atomic Power Plant, Report APDA-124, pp. 177-184, January 1959.

9. Atomic Power Development Associates, Inc., Determination of the Maximum Pressures Attained During the Reaction of Sodium with Air in a Closed System, Report APDA-EL\&RD$5.5 \mathrm{C} 80$.

10. Atomic Power Development Associates, Inc., Sodium-Air Accident Study for a Sodium-cooled Reactor, Report APDA-TM-20.

11. Atomic Power Development Associates, Inc., Effect of Decay Heat on Building Temperature, Report APDA-Memorandum 8-15-57.

12. F. B. Porzel, Design Evaluation of Boiling Water Reactor in Regard to Internal Explosions, USAEC Report ANL-5651, Illinois Institute of Technology, Armour Research Foundation, January 1957.

13. Stuart Mclain and R. O. Brittan, Safety Features of Nuclear Power Reactors, paper presented at ASME Conference held Dec. 1-6, 1957, ASME Paper 57-A-265.

14. W. SILER and L. ZICK, Design Considerations for an Atomic Power Reactor Containment Structure, paper presented at the Second Nuclear Engineering and Science Conference held in Philadelphia. 1957, ASME Paper 57-NESC-116.

15. W. E. Baker and J. D. Patterson, Blast Effects Tests of a One-quarter-scale Hodel of the Air Force Nuclear Engineering Test Reactor, Report BRL-1011, Ballistic Research Laboratories, March 1957.

16. Accidental Dispersion of Reactor Poisons and the Controlled Distance Required, USAEC Report DP 105 (Rev. 2), E. I. du Pont de Nemours \& Co., Inc., March 1958. 
17. F. B. Porzel, Illinois Institute of Technology, Armour Research Foundation, Some Hydrodynamic Problems in Reactor Containment, A/Conf. $15 / \mathrm{P} / 431$, prepared for the Second United Nations International Conference on the Peaceful Uses of Atomic Energy, September 1958.

18. H. O. Monson and M. M. Sluyter, Argonne National Laboratory and Illinois Institute of Technology, Armour Research Foundation, Containment of $E B R-I I, A / C o n f .15 / \mathrm{P} / 1892$, prepared for the Second United Nations International Conference on the Peaceful Uses of Atomic Energy. September 1958.

19. R. O. Brittan and J. C. Heap, Argonne National Laboratory, Reactor Containment, A/Conf. 15/ $\mathrm{P} / 437$, prepared for the Second United Nations International Conference on the Peaceful Uses of Atomic Energy, September 1958.

20. C. T. Chave and O. P. Balestracci, Stone and Webster Engineering Corp., Iapor Containers for Nuclear Power Plants, A/Conf. 15/P/1879, prepared for the Second United Nations International Conference on the Peaceful Uses of Atomic Energy, September 1958.

21. H. M. Parker and J. W. Heary, Environmental Effects of a Major Reactor Disaster, in Proceedings of the International Conference on the Peaceful I'ses of Atomic Energy, vol. 13, P/482, p. 106, United Nations, New York, 1956.

22. W. E. BAKER, Ballistic Research Laboratories, Aberdeen Proving Ground, Scale Model Tests for Evaluating Outer Containment Structures for Nuclear Reactors, A/Conf. 15/P/1028, prepared for the Second Inited Nations International Conference on the Peaceful Uses of Atomic Energy, September 1958.

23. C. K. BEck et al., U.S. Atomic Energy Commission, Reactor Safety, Hazards Evaluation and Inspection, A/Conf. 15/P/2407, prepared for the Second Cnited Nations International Conference on the Peaceful Uses of Atomic Energy, September 1958.

24. B. P. Leonard, Jr.. Convair, Hazards Associated with Fission Product Release, A/Conf. 15/P/428, prepared for the Second United Nations International Conference on the Peaceful Uses of Atomic Energy, September 1958.

25. J. R. Humphreys, Jr. Argonne National Laboratory, Sodium-Air Reactions as They Pertain to Reactor Safety and Containment, A/Conf. 15/ $\mathrm{P} / 1893$, prepared for the Second United Nations International Conference on the Peaceful Uses of Atomic Energy, September 1958.

26. J. S. ZIZZI and L. P. DIEHL, Leak Rate Test, Power Plant Building, West Milton Site, USAEC Report M-6065, Knolls Atomic Power Laboratory, unpublished, September 1953.
27. E. M. Fisher and W. R. Wise, Jr, Containment Study of the Enrico Fermi Fast Breeder Reactor Plant, Report NAVORD-5747, Naval Ordnance Laboratory, Oct. $7,1957$.

28. W. R. WISE, Jr., NOL Reactor Vessel Containment Program. (NOL-285, Damage from Explosion of Nuclear Reactors.), Quarterly Progress Report for the Period Jan. 1-Mar. 31, 1957, Report NAVORD-4542, Naval Ordnance Laboratory, June 28, 1957.

29. A. H. Heineman and L. W. Fromm, Argonne National Laboratory, Containment for the $E B W R$, A/Conf. $15 / \mathrm{P} / 1891$, prepared for the Second United Nations International Conference on the Peaceful Uses of Atomic Energy, September 1958.

30. H. J. Gomberg, University of Michigan, A Quantitative Approach To Evaluation of Risk in Locating a Reactor on a Given Site, A/Conf. 15/P/436, prepared for the Second United Nations International Conference on the Peaceful Uses of Atomic Energy, September 1958.

31. B. P. LeonaRd, Jr., Convair, Hazards Associated with Fission Product Release, A/Conf. 15/P/428, prepared for the Second United Nations International Conference on the Peaceful Uses of Atomic Energy, September 1958.

32. C. T. Chave and O. P. Balestracci, Stone and Webster Engineering Corp., Vapor Containers for Nuclear Power Plants, A/Conf. 15/P/1879, prepared for the Second United Nations International Conference on the Peaceful Uses of Atomic Fnergy, September 1958.

33. Power Reactor Development Compayy, First Quarterly Technical Report, pp. 34-37, unpublished, Mar. 6, 1959.

34. A. C. Chamberlain and W. J. Megaw, Safe Distances in Reactor siting, Report AERE-MP/M109 [RHM (56)/116], Great Britain Atomic Energy Research Establishment, Apr. 12, 1956, classified.

35. H. A. Bethe and J. H. TAIT, An Estimate of the Order of Magnitude of the Explosion When the Core of a Fast Reactor Collapses, Report RHM ( 56) /,113, Great Britain Atomic Energy Research Establishment, April 1956, classified.

36. S. UNTERMYER and D. L. LAYToN, Leakage Testing on the Boiling Water Reactor Enclosure, Report VAL_33, General Electric Co., Vallecitos Atomic Laboratory, September 1957.

37. Atomic Indistrial Fort'm, Inc., A New "Grouth Survey," 5(2): 20-24. (February 1958). (A growth survey of the atomic industry for the years 1958-1968, prepared by Pickard-WarrenLowe Associates of Washington, D.C.)

38. T. J. Burnetr, Reactors, Hazards rs. Power Level, Nuclear Sci. and Eng., 2: 382-393 (1957). 
39. J. R. Bohaxyox, Jr., and W. E. Baker, Simulating Nuclear Blast Effects, Nucleonics, 16(3): 74 (1958).

40. Z. M. Shapiro and T. R. MOFFETTE, Hydrogen Flammability Data and Application to PWR Loss-ofCoolant Accident, ISAEC Report WAPD-SC545, Westinghouse Hlectric Corp., September 1957.

41. Division of Crvilian Application, AEC, Theoretical Possibilities and Consequences of Major Accidents in Large Nuclear Power Plants, USAEC Report WASH-740, Superintendent of Documents, L.S. Government Printing Office, Washington 2\%, D.C., March 1957.

\section{Sodium Technology}

1. R. H. JoNes et al., NaK-Water Reaction Tests, USAEC Report AECC-3193, Atomic Power Development Associates, Inc, December 1956.

2. W. W. Kendall et al., Guide to Alkali Metals Handling. Liquid Metals Safety Committee Manual LMSC-1, CSAEC Report AECU-3143, Knolls Atomic Power Laboratory, July 1, 1954.

3. G. W. HoRsley, The Corrosion of Iron by OxygenContaminated Sodium, Report AERE-M/R-1441, Great Britain Atomic Energy Research Establishment, April 1954.

4. J. W. TAYLOR, Inhibition of Liquid-Metal Corrosion, Report AERE-M-TN-35, Great Britain Atomic Energy Research Establishment, Feb. 10, 1956.

5. A. G. WARD and J. W. TAYlor, Solution Rate Studies with Liquid Metals, Report AERE-M/R1866, Great Britain Atomic Energy Research Establishment, Feb. 23, 1956.

6. F. A. SмIтн, Sodium Handling at ANL, in Handling and C'se of Alkali Metals, Advances in Chemistry Series No. 19, Washington, American Chemical Society, 1957.

7. Aerojet-General Corp., The Reaction of Molten Metal with Water, LSAEC Report AGC-AE-35, Mar. 29, 19.57.

8. Aerojet-Gexeral CorP.. The Reaction of Molten Ietal with Water, I'SAEC Report AGC-AE-33, Jan. 28, 1957.

9. L. R. Kelmax et al., Resistance of Materials to Attack by Liquid Metals, ISAEC Report ANL4417, Argonne National Iaboratory, July 1950.

10. F. J. Tebo, Selected Values of the Physical Propertues of Various llaterials, CSAEC Report ANL5914, Argonne National Iaboratory, September 1958 .

11. W. F. Lrwdell and E. G. IAawsoy, Jr., Heat Transfer to Liqud lletals, Report ATI-166713, University of Delaware, Apr. 1, 1952.
12. Atomic Power Development Associates, Inc., Determination of the Amount of Sodium Adhering to Small-Scale Subassembly Nozzles That Were Cleaned by Flushing with oil, Report APDA EL\&RD-58D96.

13. Atomic lower Developmev't Assochates, Inc., Cleanliness-The Reasons and Need for It in the Construction and operation of the Fermi Reactor, Report APDA FM-16.

14. Atomic Power Developmext Associates, Inc., Bulk shielding Materials Compatibility Tests in Sodium (Carbon and Graphite), APDA Oct. 30, 1958, memorandum.

15. Atomic Power Development Associates, Inc., Thermocouple Acceptance Tests in Hot sodium, APDA Nov. 26, 1958, memorandum.

16. Atomic Power Development Associates, Isc., Compatibility of Fluorlube M0-10 with Sodium, APDA Test Memorandum No. 2.

17. Атом Power Development Assocrates, Inc. Displacement of Sodium with Low Melting $P$ b Sn-Bi-Cd Alloy, APDA Test Memorandum No. 1

18. Atomic Power Development Associates, Ixc. (1) Sodium Cleaning by Ultrasonics and Hydrocarbon Flushing; (2) Steam Cleaning of Sub assembly Mockup Specimens; and (\$) Steam Cleaning Test of Dummy Fuel Element Subassemblies, APDA Test Memorandum No. 3.

19. R. Carla Nder and E. E. Hoffman, Transfer of Carbon Between Dissimilar Metals in Contact with Molten Sodium, USAEC Report CF-56-473, Oak Ridge National Laboratory, Apr. 2, 1956.

20. G. W. Thомson et al., Physical and Thermodynamic Properties of Sodium, Ethyl Corp.

21. S. G. BAUER, Liquid Metal Handling, in Proceedings of the International Conference on the Peaceful Uses of Atomic Energy, vol, 9, P/866, p. 252, United Nations, New York, 1956.

22. M. A. Mikheyev et al., Heat Transfer of Molten Metals, in Proceedings of the International Conference on the Peaceful Uses of Atomic Energy, vol. $9, \mathrm{P} / 639$, p. 285 , United Nations, New York, 1956.

23. L. F. Epsteix, Corrosion by Liquid Metals, in Procepdings of the International Conference on the Peaceful I'ses of Atomic Energy, vol. 9, P/119, p. 311. Lnited Nations, New York, 1956.

24. H. Mogard, Observations on the Corrosion of Cranium in Liquid Sodium, in Proceedings of the International Conference on the Peaceful lises of Atomic Energy, vol. 9, P/787, p. 318, United Nations, New York, 1956.

25. F. A. SMith, Argonne National Laboratory, Sodium Technology for Nuclear Power Plants, A/Conf. $15 / \mathrm{P} / 2291$, prepared for the Second United Nations International Conference on the Peaceful Uses of Atomic Energy, September 1958. 
26. A. Dhayco't and P. D. Rich, Mass Transfer in Liquid Metal Circuits, A Review of Progress in Initial studies, Report IGR-TN/W-454, Windscale Works, England, January 1957.

27. W. M. Knox. Pressure Rise in a Confined Volume of Molten Sodium Cpon Addition of Heat, CSAEC Report KAPI-M-WMK-2, Knolls Atomic Power Laboratory, May 20, 1953.

28. C. O. NeLson, Summary Report of Reaction Tests of Various Materials Tested with Sodium and NaK, CSAEC Report KAPI-557, Knolls Atomic Power Laboratory, June 1, 1951.

29. J. W. Moyfer and W. A. Rrembn, Heat Transfer Measurements at Sodium-Stainless Steel Interface, J. A ppl. Phys., 25: 400-402 (1954).

30. C. O. Nelsox and D. B. Nelson, Sodium-Air Reaction Experiments, CSAEC Report KAPI-639, Knolls Atomic Power Laboratory, Jan. 1, 1952.

31. F. G. HAAG, Investigation of Radioactive Decontamination Methods for Sodium Reactor System Components, CSAEC Report KAPI-1456, Knolls Atomic Power Laboratory, Dec. 1, 1955.

32. L. B. VANDENBERG, Electrical Contact Resistance Between Sodium and Stainless steel, TSAEC Report KAPL-1502, Knolls Atomic Power Laboratory, Feb. 14, 1956.

33. H. M. SAItSBI: The Kinetics of Molten MetalWater Reactions: A Report on Na,K-Water Vapor, TSAEC Report KAPL-1763, Knolls Atomic Power Laboratory, Apr. 30, 1957.

34. Mine Safety Appliances Co., Liquid Metals Technology Abstract Bulletin for the Period July 1 to Aug. 31, 1956, Report IM/TAB-1, Sept. 7, 1956.

35. Mine Safety Appliances Co., Liquid Metals Technology Abstract Bulletin for the Period Sept. 1 to Ort. 31, 1956, Report LM/TAB-2, Nov. 1, 1956.

36. Mine Safety Appliances Co., Liquid Metals Technology Abstract Bulletin for the period Nov. 1 to Dec. 31, 1956, Report LM/TAB-3, Jan. 8, 1957.

37. B. Lubarsky and S. J. Kavfman, Review of Experimental Investigations of Liquid-Metal Heat Transfer, Report NACA-TN-3336, Lewis Flight Propulsion Laboratory, National Advisory Committee for Aeronautics, Nov. 4, 1954.

38. Niclear Developmext Corp. of A merica, Chemical Considerations in the Sodium-Cooled $\mathrm{D}_{2} \mathrm{O}$-Hoderated Reactor, I'SAEC Report NDA-84-6, Apr. 30,1958 .

39. R. N. Lyox (editor), Liquud Metals Handbook, Report NAVEXOS-P-733 (rev.), Atomic Energy Commission and Department of the Navy, available from the Superintendent of Documents, C.S. Government Printing Office, Washington 25, D.C., June 19.52.
40. F. C. Bennett, Liquid Sodium Heat Transfer, Report No. 14854, Dow Chemical Co., October 1948.

41. C. T. Ewrng, Liquid Metals: Thermal Conductivity IIcasurements, Interim Report $3230-135 \mathrm{~A} / 51 \mathrm{eb}$, Naval Research Laboratory, Oct. 23, 1951.

42. M. H. Feldman, Molecular Form of Vaporizing Sodium, LSAEC Report NAA-SR-123, North Anerican Aviation, Ine., May 21, 1951.

43. C. T. Ewing and J. A. Graxd, Measurements of the Thermal Conductivity of Sodium and Potassium, Report NRL-3835, Naval Research Laboratory, Aug. 16, 1951.

44. C. T. Ewing et al., on the Measurement of the Physical and Chemical Properties of the SodiumPotassium Alloy, Quarterly Progress Report No. 5, Report NRL-C-3201, Naval Research Laboratory, Dec. 9, 1947.

45. W. A. Selke et al., Quarterly Progress Report; Thermodynamic Properties of Sodium Vapor, USAEC Report NYO-3097, Columbia University, Jan. 1, 1952.

46. C. F. Bonilla and B. Misra, Boiling and Condensing of Liquid Netals, CSAEC Report NYO-3152, Columbia Iniversity, Apr. 25, 1953.

47. G. P. SMITH et al, Flammability of Sodium Alloys at High Temperatures, CSAEC Report ORNL1799, Oak Ridge National Laboratory, July 6, 1955.

48. R. M. BoARTs et al., Effect of Wetting on Heat Transfer Characteristics of Liquid Metals, USAEC Report ORO-121, Cniversity of Tennessee, Feb. 1, 1954.

49. E. E. Hoffman and W. D. Manly, Oak Ridge National Laboratory, Corrosion Resistance of Metals and Alloys to Sodium and Lithium, in $\mathrm{Han}$ dling and Cise of the Alkali Metals, Advances in Chemistry Series No. 19, Washington, American Chemical Society, 195\%, pp. 82-91.

50. Argonye National Laboratory, Papers Presented at the Technical Briefing Session on the Boiling Water Reactor Program and the Fast Reactor Program Held at Idaho Falls, Idaho, November 1-2, 1955, USAEC Report TID-7506 (pt. 1), July 1956.

51. C. B. Jacksox (editor), Liquid Metals Handbook, 3d edition, TSAFC Report TID-5277, Atomic Energy Commission and Bureau of Ships, available from the Superintendent of Documents, U.S. Government Printing Office, Washington 25, D. C., July 1955.

52. I. 1. Novikov et al., Heat Transfer and Thermophysical Properties of Molten Alkali Metals, Soviet J. Atomic Energy, 4: 545-560 (1956).

53. C. D. BoAdle, Liquid Metals in Nuclear Power, Atomics, 8: 83-8.7, 106 (March 1957). 
54. Enward Hines et al., How Strong Must Reactor Housings Be To Contain Na-Air Reactions?, Nucleonics, 14(10) : 38-41 (October 1956).

55. M. Sitrig, Sodium-Its Manufacture, Properties and Lses, Reinhold Publishing Corp., New York.

56. T. Trock I et al, Sodium and Sodium-Potassium Alloy for Reactor Cooling and Steam Generation, in Proceedings of the International Conference on the Peaceful Cses of Atomic Energy, vol. 9, P/123, p. 241, Inited Nations, New York, 1956.

57. Leo F. Epstein, Static and Dynamic Corrosion and Mass Transfer in Liquid Metal Systems, Chem. Eng. Progr. 53, Symposium Series No. 20:67-81 (1957).

58. K. D. Kuczen and T. R. Bump, Measurement of Local Heat Transfer Coefficients with SodiumPotassium Eutectic in Turbulent Flow, Nuclear Sci. and Eng., 2: 181-198 (1957).

\section{Metallurgy}

1. Investigation of the Properties of Cast Boron Steel, Report AC-2681.

2. Allis-Chalmers Mavufacturing Co., Materials Weld Test at Elevated Temperatures-Boron Nitride in Nickel-Matrix Coatings, Report ACNP-5704.

3. Allis-Chalmers Mavufacturing Co., Materials Weld Test at Elevated Temperatures-Nitrided Stainless steel, Report ACNP-5706.

4. H. H. Hausner and J. L. Zambrow, The Powder Metallurgy of Uranium, Nuclear Sci. and Eng., 1 : 92-101 (1956).

5. D. O. LeEser and G. J. DEILy, Effect of Irradiation on the Notched-Bar Impact Properties of Some Plain Carbon Steels, in Symposium on Radiation Effects on Matcrials, vol. 1, ASTM Special Technical Publication 208, 1957.

6. D. O. Leeser, Radiation Effects on Welds and Notehes in Plain Carbon Steels, Stainless Steels, and Nonferrous Alloys, in Symposium on Radiation Effects on Materials, vol. 1, ASTM Special Technical Publication 208, 1957.

7. S. Untermyer and J. T. Weills, Heat Generation in Irradiated Iranium, LSAEC Report AECD-3454, Argonne National Laboratory, Feb. $25,1952$.

8. J. H. KitTel and S. H. PAINe, Effects of High Burnup at Elevated Temperatures on Cranium0.52 and $1.62 u / 0$ Zirronium Alloys, CSAEC Report ANI-5406, Argonne National Laboratory, unpublished.

9. Argonne National Laboratory, Metallurgy Division Quarterly Report for January, February and March, 19.5, ISAEC Report ANL-5439(Del.), September 1955.
10. J. H. Kittel and S. H. Paine, Effects of Irradiation on Cast Specimens of Uranium-Chromium Eutectic Alloy, CSAEC Report ANL-5477, Argonne National Laboratory, December $195 \overline{5}$.

11. G. D. Calkins et al., Radiation Stability Studies on Binary Cranium Alloys, 57-NESC-109, preprint of paper presented at Second Nuclear Engineering and Science Conference, Mar. 14, 1957.

12. Argonne National Laboratory, Metallurgy Division Quarterly Report for July, August and September 1955, CSAEC Report ANL-5489, March 1956.

13. S. H. PaIne et al., Preliminary studies of Irradiation Damage to Uranium-Zirconium Alloys, CSAEC Report ANI-5537, Argonne National Laboratory, October 1956.

14. K. F. SMIth and L. R. KeLMAN, Irradiation of Cast Uranium-Plutonium Base Alloys, USAEC Report ANL-5677, Argonne National Laboratory, May 1957.

15. J. H. Krttel and L. R. Kelman, Effects of Irradiation on Some Uranium-Plutonium Alloys, USAEC Report ANL-5706, Argonne National Laboratory, January 1958.

16. K. F. SMITH, Irradiation of Tranium-Fissium Alloys and Related Compositions, USAEC Report ANL-5736, Argonne National Iaboratory, September 1957 .

17. S. T. KonobeEvsky et al., Effect of Irradiation on Structure and Properties of Fissionable Materials, in Proceedings of the International Conference on the Peaceful Uses of Atomic Energy, vol. 7, P/681, pp. 433-440, United Nations, New York, 1956.

18. Argon ne National Laboratory, Handbook of Constants for Selected Pile Materials, USAEC Report ANI-WHZ-122, Oct. 30, 1947.

19. A. Del Grosso and D. O. Leeser, The APDA Irradiation Test Program on Selected Fuel Alloys, June 1954-June 1957, Report APDA-122, Atomic Power Development Associates, Inc., 1957.

20. D. O. Leeser and R. C. Wilirams, Metallurgy Evaluation of Material Wear and Self-Welding in Sodium-Cooled Reactor Systems, Report APDA126, Atomic Power Development Associates, Inc., August 1958.

21. Atomic Power Development Assoctates, Inc., Irradiation Testing of Prototype Enrico Fermi Fuel Pins in CP-5, Report APDA-130.

22. Effect of Heat Treatment and Burn-Up on the Radiation Stability of $\mathrm{C}-10 \mathrm{w} / \mathrm{o}$ Mo Fuel Alloys, in Radiation Effects on Materials, Report STP-220, vol. II, American Society for Testing Materials.

23. Effects of Irradiation on the Type 347 Stainless Sterl Flow separator in the EBR-I Core, American Society for Testing Materials-Argonne National Laboratory report, unpublished. 
24. J. H. Kittel et al., Infuence of Heat Treatment on Irradiation-Induced Dimensional Changes in Some Uranium-Zirconium Alloys, ASTM Special Technical Publication 208, pp. 8T-99, 1957.

25. R. F. SHoner et al., Development of Dimensionally Stable Tranium Alloys, USAEC Report BMI961, Battelle Memorial Institute, Oct. 26, 1954.

26. H. A. SAller and F. A. Rough, The Properties of High-Lranium Alloys Containing Zirconium or Chromium, USAEC Report BMI-984, Battelle Memorial Institute, Feb. 21, 1955.

27. H. A. Saller et al., Properties of a Fissium-Type Alloy. CSAEC Report BMI-1123, Battelle Memorial Institute, Aug. 3, $\mathbf{1 9 5 6 .}$

28. Battelle Memoriat Ixstitcte, The Radiation Stability of Cranium-10 w/o Molybdenum as a Function of Heat Treatment and Burn-Up, Report BMI-APDA-625.

29. John E. Gates et al., Stress-strain Properties of Irradiated Cranium-10 w/o Molybdenum, USAEC Report BMII-APDA-638, Battelle MemoFlal Institute, Jan. 6, 1958.

30. Metallurgical Investigation of Fuel Element Pins Tested in Liquid sodium, Report BW-RDE7050 .

31. Atomic Power Developyent Assocrates, Inc., Experimental Investigation on Cast Carbon Steel with 1 to $1 \frac{1}{2}$ percent Boron, Report APDA-EI837.

32. Atomic Power Development Associates, Inc., Ietallographic Examination of Three Pin-Type Fuel Pins for APDA, Report APDA-EL\&RD$56 \mathbf{F} 42$.

33. Atomic Power Development Associates, Inc., Determination of Certain Properties of Anhydrous sodium Tetraborate, Report APDAEL\&RD 56G11.

34. Atomic Power Development Associates, Inc., Examination of Two Cranium-10 $w / 0$ Mo Fuel Pin Specimens for APDA, Report APDAEL\&RD 57B41.

35. Aтomic Power Development Assochates, Inc., Metallurgical Examination of Three Cranium-10 w/o Mo Fuel Rods to Determine Conformance to APDA specifications, Report APDA-EL\&RD 57B52-1.

36. Atomic Power Development Associates, Inc., Determination of the Chemical Composition of Three Cranium-Molybdenum Fuel Rods, Report APDA-EL\&RD 57B52-2.

37. Atromic Power Deielopment Associates, Ixc., Examination of Two Cranium-10 w/o Mo Fuel Pin Specimens for APDA, Report APDAEL\&RD 57B76.

38. Аtomic Power Developmext Associates, Inc., Examination of Three $I^{7}-10$ w/o Mo Fuel Pins
Before and After Heat Treatment, Report APDA-EL\&RD 57C84.

39. Atromic Power Development Associates, Inc., Examination and Heat Treatment of Three Zirconium-Clad Cranium-10 w/o Mo Fuel Pins for APDA, Report APDA-EL\&RD 57E21-1.

40. Aтomic Power Development Associates, Inc., Evaluation of Two Types of Borated Insulating Materials, Report APDA-EL\&RD 58C49.

41. Atomic Power Development Associates, Inc., Determination of Linear Coefficient of Thermal Expansion of Serpentine Concrete, Report APDA-EL\&RD 58D11.

42. Атомi Power Development Associates, Inc., Examination of Spot Welds Used to Join Croloy-5 Fins to A Croloy 21/4 Tube Representing a Finned-Pot Transfer Container, Report APDAEL\&RD 50874.

43. R. E. Hueschen and C. H. PItT, Initial Investigation of the Mechanical Properties of Uranium at Elevated Temperatures, USAEC Report HW26426, Hanford Works, 1952.

44. R. O. Elliot and R. E. TAte, A Determination of the Coefficient of Thermal Expansion of Alpha Plutonium, USAEC Report LA-1390(Del.), Los Alamos Scientific Laboratory, Mar. 3, 1952.

45. M. B. Waldron and A. G. Hardina, Thermal $C y$ cling of Iranium Bars Through Alpha-Beta Transition Temperature, Report LEO/A-28, Great Britain Atomic Energy Research Establishment.

46. I. R. Aronin and J. J. Pickett, Core-to-Clad Interdiffusion Studies on Zirconium-Clad $U-10$ w/o Mo Alloy Fuel Pins, I'SAEC Report NMI-4403, Nuclear Metals, Inc., Jan. 10, 1958.

47. Progress Report to APDA on the Determination of True Stress-True Strain Curves and Modulus of Elasticity of a Cranium-10 $w / 0$ Molybdenum Alloy at Elevated Temperatures, Report SRI-3312-734-5-1.

48. Progress Report to APDA on Antimony Corrosion Tests, Report SRI-3359-734-I, -II, -III.

49. Determination of True-Stress True-Strain Curves and Modulus of Elasticity of a Vranium-10 w/o Molybdenum Alloy at Elevated Temperatures, Report SRI-3535-734-5-II.

50. Atomic Power Development Associates, Inc., Compilation of Cranium-10 w/o Molybdenum Fuel Alloy Properties, Report APDA-TM-3.

51. Atromic Power Development Associates, Inc., Special Nuclear Materials Required and Produced, Report APDA-TM-6.

52. E. EPREMIAN (editor), Cranium Alloy Newsletter, USAEC Report WASH-701, Division of Research, AEC, February 1957.

53. Dounreay Fast Reactor. Here Is How It Works, Nuclear Power 2: 240-241 (June 1957). 
54. J. H. Kittell and K. F. SMith, Argonne National Laboratory, Irradiation Behavior of UraniumFissium and Uranium-Plutonium-Fissium Fast Reactor Fuels, in Fuel Elements Conference Held in Gatlinburg, Tenn., May 14-16, 1958, USAEC Report TID-7559 (pt. 1), Division of Research, AEC; Division of Reactor Development, AEC; and Oak Ridge National Laboratory, unpublished.

55. F. G. Foote, Physical Metallurgy of Uranium, in Proceedings of the International Conference on the Peaceful Uses of Atomic Energy, vol. 9, $P / 555$, pp. 33-68, United Nations, New York, 1956.

56. J. H. Kittell and S. H. PAINe, Effect of Irradiation on Fuel Materials, A/Conf. $15 / \mathrm{P} / 1890$, prepared for the Second United Nations International Conference on the Peaceful Uses of Atomic Fnergy, September 1958.

57. D. O. LFEsER et al., Radiation Stability of Fuel Elements for the Enrico Fermi Pouer Reactor, A/Conf. $15 / \mathrm{P} / 622$, prepared for the Second United Nations International Conference on the Peaceful Uses of Atomic Energy, September 1958.

58. J. A. HoRAK and J. H. Kittell, Irradiation Behavior of Uranium-Fission and Lranium-Plutonium-Fissium Fast Reartor F'uels, paper prepared for the Session on Nuclear Metallurgy, American Institute of Mining, Metallurgical, and Petroleum Engineers, to be held in November 1959.

59. M. I. Bueiberg et al., Phase Changes in Pile Irradiated Uranium-Base Alloss, J. Appl. Physics, 27: 1270-1283 (1956).

60. E. W. Colback, Uranium Alloys, Nuclear Eng., 2: 172 (1957).

61. S. H. Paine and J. H. Kittel, Irradiation Effects in Uranium and Its Alloys, in Proceedings of the International Conference on the Peaceful Uses of Atomic Energy, vol. 7, P/745, pp. 445-454, United Nations, New York, 1956.

62. F. G. Foote, Physical Metallurgy of Uranium, in Proccedings of the International Conference on the Peaceful Uses of Atomic Energy, vol. 9, $P / 555$, pp. 33-68, Cnited Nations, New York, 1956.

63. S. F. Prgh, Radiation Damage in Fissile Materials, in Progress in Nuclear Energy, Series $V$, Metallurgy and Fuels, vol. 1, pp. 652-671, Pergamon Press, Inc., New York, 1956.

64. D. W. Whiтe, Jr., Transformation Kinetics in Uranium-Chromium Alloys, J. Metals, $7(11)$ : 1221 (1955).

65. S. Greeniserg and J. F. Draley, Effects of Irradiation on Corrosion Resistance of Some High Uranium Alloys, Nuclear Sci. and Eng., 3: 19-28 (1958).
66. H. H. ChIswik et al., Advances in Uranium and Uranium Alloys, A/Conf. 15/P/713, prepared for the Second United Nations International Conference on the Peaceful Uses of Atomic Energy, September 1958.

67. J. E. Draley et al., The High Temperature Aqueous Corrosion of Uranium Alloys Containing Minor Amounts of Niobium and Zirconium, USAEC Report ANL-5530, Argonne National Laboratory, April 1957.

68. L. Burris et al., Developments in Melt Refining of Reactor Fiuels, A/Conf. 15/P/538, prepared for the Second United Nations International Conference on the Peaceful Uses of Atomic Energy, September 1958.

69. M. L. Bueiberg et al., l'hase Changes in PileIrradiated Uranium-Base Alloys, J. Appl. Phys., 27: 1270-1283 (1956).

70. S. T. Konobevvsky et al, Effect of Irradiation on Structure and Properties of Fissionable Materials, in Proceedings of the International Conference on the Peaceful Cres of Atomic Energy, vol. 7, P/681, pp. 433-440, United Nations, New York, 1956.

71. B. R. HAYWARD and C. G. BentLe, Effects of BurnUp on Metallic Fuel Elcments Operating at Elevated Temperatures, A/Conf. 15/P/617, prepared for the Second Inited Nations International Conference on the Peaceful Uses of Atomic Energy, September 1958.

72. J. H. Handwerk et al,, Thoria and Crania Bodies, Bull. Am. Ceram. Soc., 36: 99-101 (1957).

\section{Fuel Element Development and Test}

1. Ailis-Chalmers Manufacturing Co., Fuel Element Melt-Down Boiling Sodium study for $A P D A$, Report ACNP-5702.

2. A. B. Sнuск, Development of Methods for Casting and Fabricating Enriched Uranium Fuel slugs, USAEC Report ANL-4617, Argonne National Laboratory, Apr. 18, 1951.

3. Robert E. MACHEREY, Casting of Blanket Bricks, Ring, Plug, and Control Rods for the Experimental Brceder Reactor (CP-4), USAEC Report ANL-5009, Argonne National Laboratory, Mar. 19, 19.53 .

4. A. B. SHUCK, The Development of Equipment and Methods for Centrifugally Casting Reactor Fuel Slugs, I'SAEC Report ANL-5123, Argonne National Laboratory, Sept. 29, 1953.

5. K. F. Sмгтн et al., Mechanical Stabilization of Cranium Fuel Elements, USAEC Report ANL5377, Argonne National Iaboratory, November 1956. 
6. F. L. YAGGEE, The Manufacture of Enriched ZPRIII Fuel Plates, CSAEC Report ANL-5599, Argonne National Laboratory, October $\mathbf{1 9 5 6 .}$

7. Enrico Fermi Reactor Control and Fuel Reloading Cycle, ANS.

8. Battelle Memoriai. Institute, Methods for EndCapping APDA Fuel Pins, Report BMI-APDA631.

9. Battelle Memorial Institute, $A$ Study of Core Fuel Systems for a Fast Breeder Power Reactor, Report BMI-APDA-636.

10. Battelle Memorial Institute, $A$ study of Core Fuel Systems for a Fast Breeder Power Reactor-Addendum I, Report BMI-APDA-641.

11. Battelle Memorial Institute, $A$ study of Core Fuel Systems for a Fast Breeder Power Reactor-Addendum II, Report BMI-APDA-643.

12. Battelle Memorial Institute, Studies for the Preparation of Zirconium Clad Cranium-10 $\mathrm{w} / \mathrm{o}$ Molybdenum Fuel Pins, Report BMI-APDA-644.

13. BABCOCK \& WrLCOX Co., Examination of Fuel Element Pins Tested for One Month in Sodium at $1,000^{\circ} F$. Report BW-7117.

14. BABCoCK \& Wilcox Co., Examination of Fuel Element Pins Tested for Five Nonths in Sodium at $1,000^{\circ} \mathrm{F}$., Report BW-7152.

15. BABCoCK \& Wilcox Co., The Development of Swaged End Caps for Atomic Power Development Associates, Inc., Fuel Pins, Report BW7153.

16. Atomic Power Development Associates. Inc., Thermal Cycle Test of an APDA Fuel Pin, Report APDA-EL\&RD-56530.

17. Atomic Power Development Associates, Inc. Thermal Cycle Test in Sodium of an APDA Fuel Pin, Report APDA-EL\&RD-57C05-1.

18. Атоmic Power Deveropment Assoctates, Inc., Measurement of Zirconium Cladding of Selected Uranium Fuel Pins, Report APDA-EL\&RD58E77.

19. Atomic Power Development Associates, Inc., Examination and Heat Treatment of ZirconiumClad Lranium-23/4 w/o Molybdenum Blanket Pins, Report APDA-EL\&RD-58E92.

20. Aтоmic Power Deveropment Associates, Inc., Controlled Bouing of Fuel Subassemblies, Report APDA-FI F-A2022.

21. Aтomic Power Developantent Associates, Inc., Analysis of Strcsses Induced in Core Subassembly Cans by Thermal Bowing, Report APDA-FI project A 2022-07.

22. Atomic Power Dhyelopment Associates, Inc., Recommendation for an Improved Core Development Program, Report APDA-FM-10.

23. Atomic Power Development Associates, Inc., Recommendation for the SRE Irradiation Test of a Modified APDA Fuel Subassembly, Report APDA-FM-11.

24. Atomic Power Deveropment Associates, Inc., Recommendations Concerning the Examination. Requirements for Radioactive Material From the Enrico Fermi Power Reactor, Report APDAFM-12.

25. Atromic Power Development Associates, Inc., Evaluation of Core Fuel Considerations for Fermi I Third Core Loading, Report APDAFM-15.

26. Atomic Power Development Associates, Inc., Distortion Analysis of a Reactor Fuel Subassembly, Report APDA-GM-34-716.

27. L. O. Sur.r.rvan, Problems and Costs Encountered in the Handling of Irradiated Fuels, USAEC Report KAPL-1443, Knolls Atomic Power Laboratory, Sept. 1, 1955.

28. Nuclfar Development Corp. of America, Conservative Anti-Freeze Spacing for Axial Blanket Pins, Report NDA-Memo-14-174.

29. Harold G. Elrod, Jr., Transient Fuel and Coolant Temperatures in the Enrico Fermi Reactor Core During a Period of Flow Reversal, USAEC Report NDA-14-179, Nuclear Development Corp. of America, July 30, 1957.

30. H. G. ElRod, Jr., Freezing and Remelting of Radioactive Material on Cold, Vertical Pins, USAEC Report NDA-14-181, Nuclear Development Corp. of America, July 1, 1957.

31. J. J. Prcketr and L. R. Aronin, Investigation of Coextrusion as a Method of Producing Tantalum-Clad U-10 w/o Mo Pin-type Fuel Elements, USAEC Report NMI-4404, Nuclear Metals, Inc., Jan. 23, 1958.

32. W. N. McDaniel et al., Baltimore Gas and Electric Co. and Atomic Power Development Associates, Inc., Development of Core Elements for the Enrico Fermi Power Reactor, A/Conf. 15/P/792, prepared for the Second United Nations International Conference on the Peaceful Uses of Atomic Energy, September 1958.

33. Keport on the Pressure Drop Calculations for Proposed APDA Liquid Sodium Filter Assembly, Report APDA-Purolator $\mathbf{P} / \mathbf{N} 8,000,187$.

34. L. R. Kenman, Argonne National Laboratory, Fast Reactor Fuel Development at Argonne National Laboratory, in Fuel Elements Conference, Paris, Nov. 18-29, 195\%, USAEC Report TID-7546 (Bk. 2), pp. 751-777.

35. Atomic Power Development Associates, Inc., Heat Transfer From spent Fuel and Blanket Subassemblies During Transfer From Reactor to Decay storage Facility, Report APDA-TM-2.

36. Aтomic Power Deveiopment Associates, Inc. Some Aspects of the Bouting Problem, Report APDA-TM-5. 
37. Atomic Power Development Associates, Inc., Tests on Models of Nuclear Reactor Elements, Report APIAA-UM-2431-1-P.

38. Atomic Power Development Associates, Inc., Tests on Models of Nuclear Reactor Elements: II-Studies of Diffusion, Report APDA-UM2431-2P.

39. Atomic Power Development Associates, Inc., Tests on Models of Nuclear Reactor Elements: III-Head Losses in Core Subassemblies, Report APDA-UM-2431-3P.

40. Atomic Power Development Associates, Inc., Thermal Bouing of Individual Fuel Pins, Report APIA-UM.

41. Atomic Power Development Assoctates, Inc., Thermal Bowing of Fuel Pins-Parts I, II, Report APDA-UM.

42. Aтомic Power Development Associates, Ixc., APDA Cost Analysis of Production of Fuel Pin Cartridge Hydraulic Model No. 5.

43. Development of Plutonium-Containing Fuels at Argonne National Laboratory, in ASM Conference on the Metal Plutonium November 4 and 5 , $195 \%$.

44. Atomic Power Dfenelopment Assochates, Inc., APDA Nondestructive and Destructive Testing of APDA Fuel Rods.

45. Aтomic Power Development Assoctates, Inc., APDA Remote Fabrication of Fuel ElementsA Study of Equipment and Associated Costs.

46. Atomic Power Development Associates, Inc., APDA Report on Core and Blanket Design and Technology.

47. W. N. McDanier et al., Baltimore Gas and Electric Co. and Atomic Power Development Associates, Inc., Development of Core Elements for the Enrico Fermi Poucer Reactor, A/Conf. 15/P/792, prepared for the Second United Nations International Conference on the Peaceful Uses of Atomic Energy, September 1958.

\section{Fuel Reprocessing}

1. Milton Levenson, Conversion Ratio of the EBR by Radio Chemistry. USAEC Report ANL-5095, Argonne National Laboratory, Dec. 23, 1953.

2. L. Bu'rRIS, Jr., et al., Developments in Melt Refining of Reactor Fucls, prepared for the Second United Nations International Conference on the Peaceful Uses of Atomic Energy, September 1958.

3. H. M. Feder and R. J. TeItel, Purification of Reartor Fuels and Blankets by Crystallization From Liquid Metal Solvents, A/Conf. 15/P/540, prepared for the Second Cnited Nations International Conference on the Peaceful Lses of Atomic Energy, September 1958.
4. I. J. Kосн et al., An Integrated Unmoderated Nuclear Power Plant, A/Conf. 15/P/1782, prepared for the Second United Nations International Conference on the Peaceful Uses of Atomic Energy, September 1958.

5. J. H. SchraIdt and M. Levenson, Developments in Pyrometallurgical Processing, A/Conf. 15/P/ 1795, prepared for the Second United Nations International Conference on the Peaceful Uses of Atomic Energy, September 1958.

6. Rolf O. LingJaerde, Separation of Plutonium from Irradiated Uranium, and Fractionation of LongLived Fission Products by Ion Exchange, Report JENER-48, Joint Establishment for Nuclear Energy Research, April 1957.

7. H. WARD Alter et al., A One-Cycle Process for the Recovery and Decontamination of Plutonium, USAEC Report KAPL-1748, Knolls Atomic Power Laboratory, Jan. 2, 1957.

8. J. KosLov, Conceptual Design of Pyro-Metallurgical Reprocessing Plant for Atomic Power Development Associates, Report KLX-1759, Vitro Corp. of America, Jan. 31, 1956.

9. V. J. Salemme et al., Conceptual Design of Re mote Refabrication Plant for Atomic Power Development Associates, Report KLX-1752, Vitro Corp. of America, Feb. 29, 1956.

10. A. E. ERhand et al., Processing of the Core Fuel Used Initially in the Experimental Breeder Reactor (EBK-I), USAEC Report IDO-14331, Phillips Petroleum Co., Dec. 15, 1955.

11. J. R. Foltz et al., Hot Cell Apparatus for Pyroprocessing Experiments, USAEC Report NAASR-1227, Atomics International, June 15, 1956.

12. ARchie G. BUyers, The Pyrochemical Recycling of Plutonium from Spent to Fresh Iranium Fuel Using Molten $\mathrm{CF}_{\mathrm{F}}$ as Transfer Medium, USAEC Report NAA-SR-1435, North American Aviation, Inc., Oct. 1, 1955.

13. A. G. Buyers and E. E. MotTa, Pyrometallurgical Processes for Thorium-Cranium Fuel, USAEC Report NAA-SR-1710, Atomics International, Feb. 1, 1957.

14. M. Levenson, Argonne National Laboratory, $A$ Pyrometallurgical Processing Mcthod for $\mathrm{Nu}$ clear Fuels, paper presented at the First Nuclear Engineering and Science Congress, Cleveland, 195.5 .

15. D. C. Hampson et al., Equipment for Purification of Spent Fuel by Melt Refining, in Sixth Hot Laboratory and Equipment Conference, p. 54, Chicago, 1958.

16. G. Bernsteis et al., Design for a Remotely Operated Facility for High Temperature Processing of Spent Reactor Fuel, in Sirth Hot Laboratories and Equipment Conference, p. 38, Chicago, 1958. 
17. M. Levenson, Argonne National Laboratory, New Developments in Fuel Element Processing, in $A$ Rcport of the Power Reactor Fuel Processing Symposium Held July 12-13, 1955, at Oak Ridge National Laboratory, ISAEC Report ORO-144, pp. 206-229, Oak Ridge Operations Office, AEC, October $195 . \overline{5}$, classified.

18. W. M. SAMPSON, Jr., Solution of Experimental Breeder Reactor Slugs, CSAEC Report ORNL1137, Oak Ridge National Laboratory, Mar. 11, 1952.

19. M. Levenson, Processing of Spent Fuel, in Papers Presented at the Technical Briefing Session on the Boiling Water Reactor Program and the Fast Reactor Program, Held at Idaho Falls, Idaho, November 1-2, 1955, CSAEC Report TID-7506 (pt. II), p. 19.

20. J. H. Schraidt et al., Pyrometallurgical Processing: Economics and Proposed Engineering Applications, in Symposium on the Reprocessing of Irradiated Fuels, Held at Brussels, Belgium, May 20-25, 195\%, I'SAEC Report TID-7534 (book 2), p. 748, Atomic Energy Commission, 1957.

21. M. Levenson et al., EBR-II Fuel Cycle and Reprocessing, in Solid Fuel Reactors, Joseph R. Dietrich and Walter H. Zinn (editors), pp. 166-189, Addison-Wesley Publishing Co., Inc., Reading, Mass., 1958.

22. Frank R. Bruce, Look for Nuclear Fuel Reprocess-

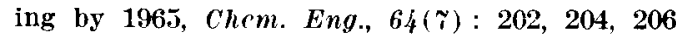
(July 1957).

23. S. Lawroski and W. A. Ronger, New Processes Promise More Economic Fission Product Removal, Chem. Eng. Progr., 53: 70F-71F (1957).

24. Edward L. Anderson, Jr., Nuclear Fuel Reprocessing. Its Status and Direction, Chem. Eng. Progr., $53(6): 19-22(1957)$.

\section{Component Development}

1. J. F. CAGE, Description and Test Results of a 400GPI Iiquid Metal Induction Pump, USAEC Report AECD-3459, Knolls Atomic Power Laboratory, oct. 23, 1951.

2. M. Granhill, Homopolar Generators and Liquid Hetal Brushes, Report AERE-Inf/Bib-92, Great Britain Atomic Energy Research Establishment, 1954.

3. M. GreenhiL, Electromagnetic Pumps and Flowmeters. A Bibliography of Literature References and Readily Available Reports, Report AERE-Inf/Bib-93, Great Britain Atomic Energy Research Establishment, Apr. 30, 1954.
4. A. H. BArNes, Electromagnetic Pump for Liquid Metals, USAEC Report AECD -3431, Argonne National Laboratory, July 15, 1949.

5. A. H. Barnes, Direct Current Electromagnetic Pumps, Nucleonics 11(1) : 16-21 (1953).

6. A. H. Barnes, Large Current Homopolar Generator, USAEC Report ANL-4361, Argonne National Laboratory, Oct. 27, 1949.

7. H. G. Elrod, Performance and Theory of a New Design of High-Temperature Electromagnetic Pump; Technical Report No. II, Report DC-517-15, Babcock \& Wilcox Co., July 13, 1951.

8. W. A. HeYwood, Frozen Sodium Shaft Seal, USAEC Report KAPL-1265, Knolls Atomic Power Laboratory, Aug. 4, 1954.

9. JoAN Barnard and G. D. Collins, Test of 1200 GPM Linear A-C Electromagnetic Pump, USAEC Report AECD-3460, Knolls Atomic Power Laboratory, May 23, 1951.

10. LEONARD B. VANDENBERG, Homopolar Generator Pump for Liquid Metals, USAEC Report AECD3368, Knolls Atomic Power Laboratory, Aug. 13, 1951 .

11. B. G. VOORHEEs, Interim Report on Cold Trap Investigations, USAEC Report KAPL-612, Knolls Atomic Power Laboratory, Oct. 1, 1951.

12. J. F. CAGE, Jr., and E. H. Schосн, Description and Test Results of a 400-GPM Liquid Metal Induction Pump, USAEC Report AECD-3459, Knolls Atomic Power Laboratory, Oct. 23, 1951.

13. G. D. Coltins, Operation and Analysis of a 100PSI Ellectromagnetic Pump, USAEC Report KAPL_668, Knolls Atomic Power Laboratory, Jan. 19, 1952.

14. Lewi Tonks, Calculations on a D.C. Electromagnetic Pump, USAEC Report KAPL-M-Lt-3, Knolls Atomic Power Laboratory, June 16, 1948.

15. Kellex CoRP., Magnetic Induction Flowmeter Development, USAEC Report KLX-1347, June 6, 1951.

16. J. J. Marquin, An Investigation of Electromagnetic Pump Failures, USAEC Report KAPL-M-JJM-1, Knolls Atomic Power Laboratory, May 3, 1954.

17. Walter R. WIsE, Jr., Calculation of the Energy Absorption Potential for the Blast Shield of the Argonne National Laboratory Nuclear Reactor, $E B R-I I$, Report NAVORD-4470, Naval Ordnance Laboratory, Feb. 25, 1957.

18. A. R. Jones, A 50-KW DC Electromagnetic Pump for Liquid Metal Application, USAEC Report WIAP-M-30, Westinghouse Electric Corp., 1953.

19. Bendix Aviation CorP., Report on Conceptual Design of Shim Rod Actuators, Bendix Report No. 950-Research Laboratory.

20. F. R. BEyer, Some Notes on the Strength of the Enrico Fermi Reactor Vessel Structure, Mech. Eng., 81(1A) : 66-72 (January 1959). 
21. R. Cygan, SRE Pump Development in Sodium Graphite Reactor Quarterly Progress Report for January-March 1956, LSAEC Report NAA-SR1622, pp. 58-61, North American Aviation, Inc., 1956.

22. Strain Gage Test Values from Hydrostatic Testing of APDA Reactor Vessel, Report CE-1025.

23. An Experimental Study of Stresses Due to Piping Reactions on the 30-Inch Outlet Nozzles of the APDA Reactor, FI Report F-A2022.

24. argonne National Laboratory, Eddy current Tester, ANL Model A-Z Construction and Operational Hints, ANL Report.

25. R. W. LockhaRT et al., Removal of SIR Project Model steam Generator Integrity, USAEC Report KAPL-1450, Knolls Atomic Power Laboratory, Nov. 1, 1955.

26. Aтomic Power Development Associates, Inc., Considerations in the Design of the Nuclear Instrumentation system for the Enrico Fermi Atomic Power Plant, Report APDA TM-7.

27. Атомic Power Development Associates, Inc., Shielding on 30-Inch Pipe, Report APDA TM-10.

28. F. G. Haмmit, Considerations for Selection of Liquid Metal Pumps, Chem. Eng. Progr., 5.9. 249-253 (May 1957).

29. C. H. Scherbeliut, Decay-Heat Cooling Requirements of Spent Fuel from EBR-II, Nuclennics. 14(12) : 57-60, 62 (December 1956).

30. D. A. Watт, Electromagnetic Pumps for Liquid Metals, Engineering, 181(4709) : 264-268 (Anril 1956).

31. A. H. Barnes, Pumping of Liquid Metals, in Proceedings of the International Conference on the Peaceful Uses of Atomic Energy, vol. 9, P/121, p. 259, Linited Nations, New York, 1956.

32. Atomic Power Development Associates, Inc., Thermal Shock Tests on a Simulated Finned Pot Transfer Container Composed of Armco Iron Fins on a Stainless Steel Tube, Report APDAEL\&RD-58E49.

33. Atomic Power Development Associates, INC., Examination of Spot Welds Used to Join Croloy-5 Fins to a Croloy-21/4 Tube Representing a Finned-Pot Transfer Container, Report APDAEL\&RD-58D74.

\section{Reactor Design and Development}

1. R. H. Shannon et al., A study of Ellectric Power Generation Utilizing Heat Energy from Power Breeder Reactors, USAEC Report AECD-3444, Knolls Atomic Power Laboratory, Nov. 19, 1951.

2. H. V. Lichtenberger, Experimental Brecder Project Report for Period of Dcc. 1, 1948, through Feb. 28, 1949, USAEC Report ANL 4274, Argonne National Laboratory, Apr. 12, 1949.
3. H. V. LichteNBERgER, Experimental Breeder Reactor Project; Report for the Period of Mar. 1, 1949, through Jan. 31, 1950, USAEC Report AECD-3925, Argonne National Laboratory, Mar. $13,1950$.

4. R. A. CAMERON et al., Experimental Breeder Reactor Project. Report for the Period Feb. 1, 1950, through Mar. 31, 1951, USAEC Report ANL-4554, Argonne National Laboratory, Apr. 1, 1951.

5. Argonne National Laboratory, Reactor Engineering Division Quarterly Report for April, May, June 1956. Sec. II, USAEC Report ANL-5601, December 1956.

6. Argonne National Laboratory, Reactor Engineering Division Quarterly Report-Sec. II for July, August, September 1956, USAEC Report ANL5657, December 1956.

7. J. H. KITTEL, The EBR-I Meltdown-Physical and Metallurgical Changes in the Core, USAEC Report ANL-5731, Argonne National Laboratory, November 1957.

8. L. J. Косн et al., Experimental Breeder Reactor II (EBR-II) ; Hazards Summary Report, USAEC Report ANI-5719, Argonne National Laboratory, May 1957.

9. Argonne National Laboratory, Engineering Report on $E B R-I I$, USAEC Report ANL-5788, unpublished.

10. Atomic Power Development Associates, Inc., Information Report by APDA Covering Work for the Period of Aug. 1, 1954, to Jan. 31, 1955, USAEC Report APIAA-102.

11. Atomic Power Development Associates, Inc., Unclassified Description of Proposed Developmental Fast Neutron Breeder Reactor, Report APDA-104, unpublished.

12. D. J. RITCHIE, Transient Temperature Simulation of the Proposed APDA Reactor, Report APDA106, Atomic Power Development Associates, Inc., unpublished.

13. Atomic Power Development Assochates, Inc., Description of Developmental Fast Neutron Breeder Power Reactor Plant, USAEC Report APDA-108.

14. Atomic Power Development Associates, INc., Enrico Fermi Fast Breeder Reactor Plant, USAEC Report APDA-115.

15. Atomic Power Development Associates, Inc., Evaluation of Performance of PRDC Reactor, Report APDA-116.

16. Atomic Power Development Associates, Inc., Enrico Fermi Atomic Power Plant, Report APDA-124.

17. Atomic Power Development Associates, Inc., A Plutonium-Fueled Fast Breeder ReactorElectric Power Plant, Report APDA-129. 
18. INGARD M. Clausen, Jr., Transient and SteadyState Temperatures in a Liquid Metal Cooling system, USAEC Report KAPL-M-IMC-1, Knolls Atomic Power Laboratory, Dec. 17, 1952.

19. R. MELA, Progress Report on EBR-work, Report NDA-14-104, Nuclear Development Corp. of America, unpublished.

20. JoHN E. VISCARDI (editor), Reactor Heat Transfer Progress, USAEC Report NDA-33, Nuclear Development Corp. of America, Feb. 14, 1957.

21. A. B. MARTIN (editor), Reactor Evaluation Quarterly Progress Report for May-July 1953, USAEC Report NAA-SR-282, North American Aviation, Inc., Oct. 20, 1953.

22. E. T. JuRneY et al., Disassembly of the Los Alamos Fast Reactor, USAEC Report LA-1575, Los Alamos Scientific Laboratory, July 1953.

23. E. T. JURney et al., The Los Alamos Fast Plutonium Reactor, USAEC Report LA-1679, Los Alamos Scientific Laboratory, May 1954.

24. R. M. KinhN et al., A Molten Plutonium Fueled Reactor Concept-LAMPRE, USAEC Report LA-2112, Los Alamos Scientific Laboratory, January 1957.

25. H. A. Brammer, Fast Reactor Coolant Comparison, USAEC Report LWS-24701, California Research \& Development Co., Dec. 15, 1952.

26. J. E. MaHLmeister et al., Recommended PBR Conceptual Design Program, USAEC Report LWS22534, California Research \& Development Co., Mar. 10, 1953.

27. J. W. Kendall and T. M. Fry, The Dounreay Fast Reactor Project, in Proceedings of the International Conference on the Peaceful Uses of Atomic Energy, vol. 3, P/405, p. 193, United Nations, New York, 1956.

28. A. H. Barnes et al., The Engineering Design of EBR-II, a Prototype Fast Neutron Reactor Power Plant, in Proceedings of the International Conference on the Peaceful Uses of Atomic Energy, vol. 3, P/501, p. 330, Lnited Nations, New York, 1956.

29. H. Cartwrieht, United Kingdom Atomic Energy Authority, The Dounreay Fast Reactor-Basic Problems in Design, A/Conf. 15/P/274, prepared for the Second United Nations International Conference on the Peaceful Uses of Atomic Energy, September 1958.

30. L. J. Koch et al., Argonne National Laboratory, Construction Design of EBR-II: An Integrated VInmoderated Nuclear Power Plant, A/Conf. 15/P/1782, prepared for the Second United Nations International Conference on the Peaceful Ises of Atomic Energy, September 1958.

31. A. I. LeIPunsky et al., USSR, Experimental Fast Reactors in the Soviet Union, A/Conf. 15/P/
2129, prepared for the Second Lnited Nations International Conference on the Peaceful Uses of Atomic Energy, September 1958.

32. A. Amorosi and J. G. Yevick, Atomic Power Development Associates, Inc., An Appraisal of the Enrico Fermi Reactor, A/Conf. 15/P/2427, prepared for the Second United Nations International Conference on the Peaceful Uses of Atomic Energy, September 1958.

33. A. P. Donvel et al., Atomic Power Development Associates, Inc., Power Reactor Development Co., and Detroit Edison Co., Enrico Fermi Atomic Power Plant, A/Conf. 15/P/1850, prepared for the Second United Nations International Conference on the Peaceful Uses of Atomic Energy, September 1958.

34. Joseph R. Dietrich and WAlter H. ZinN, Solid Fuel Reactors, Addison-Wesley Publishing Co., Reading, Mass, 1958.

35. Argonne National Laboratory, Papers Presented at the Technical Briefing Session on the Boiling Water Reactor Program and the Fast Reactor Program, Held at Idaho Falls, Idaho, Nov. 1-2, 1955, USAEC Report TID-7506 (pt. II), July 1956.

36. EBR-I Core: After Meltdown, Nucleonics, 15(1) : 84 (January 1957).

37. Enrico Fermi Reactor. Design of First Fast Breeder, Nucleonics, 15 (4) : 68-72 (April 1957).

38. The Building of Dounreay, Atomics, 8: 201-206 (June 1957).

39. The Dounreay Fast Reactor. Here is How it Work, Nuclear Power, 2: 240-241 (June 1957).

40. The Dounreay Fast Reactor, Nuclear Power, 2: 224-228 (June 1957).

41. First Large Scale Breeder Reactor. The UKAEA's New Installations at Dounreay, Atomics, 8: 158-161 ( May 1957).

42. Dounreay, Part II, Nuclear Eng., 2: 286-293 (July 1957).

43. Dounreay : The Fast Reactor, etc., Nuclear Eng., 2: 230-244 (June 1957).

44. The World's Reactors. No. 12. Dounreay, Nuclear Eng., 2: 238a (June 1957).

45. Fast Breeder Power Reactor. Their Problems and Prospects, Nucleonics, 15 (4) : 62-66 (April 1957).

46. The Fnrico Fermi Power Reactor, Nuclear Eng., 2: 112-113 (March 1957).

47. H. V. I.IChtenberger et al., Operating Experience and Experimental Results Obtained from an NaK-Cooled Fast Reactor, in Proceedings of the International Conference on the Peaceful Uses of Atomic Energy, vol. 3, P/813, p. 345, United Nations, New York, 1956. 
48. W. H. ZinN, Review of Fast Power Reactors, in Proceedings of the International Conference on the Peaceful Uses of Atomic Energy, vol. 9, P/814, p. 198, United Nations, New York, 1956.

49. V. S. Chirkin, Systems of Heat Removal from Nuclear Reactors, J. Nuclear Energy, 5(1) : 124134 (1957).
50. 'T. M. Fry, Zephyr-Zero Energy Fast Reactor, Nuovo cimento (10) 4, suppl. No. 3: 1324-1328 (1956).

51. L. R. SHePherd, The Zero-Energy Fast Breeder Reactor, Zephyr, Brit. J. Appl. Phys. suppl. No. 5: 32-41 (1956). 